Regenerating the Experimental Farm:

\title{
How Can Architecture Make a Historic Landscape Relevant to a Contemporary Public?
}

\author{
by \\ Stephanie Murphy
}

\begin{abstract}
A thesis submitted to the Faculty of Graduate and Postdoctoral Affairs in partial fulfillment of the requirements for the degree of
\end{abstract}

Master of Architecture

Carleton University

Ottawa, Ontario

(C) 2016, Stephanie Murphy 


\section{ABSTRACT}

The original intention for Ottawa's Experimental Farm was to demonstrate and showcase a broad spectrum of agriculture-related activities and technologies. Once located on the outskirts of Ottawa, the Farm still researches rural farming methods despite now being surrounded by suburban neighbourhoods. The Farm's deterioration of identity caused by poor accessibility and lack of public programming has been recognised by the city and local residents.

A reinvigorated Farm will uphold its role as an agricultural research centre in a context relative to its urban environment. The Farm will become a place of active education, exploring sustainable relationships with the land by combining scientific research, food cultivation and water management.

Through architecture and landscape architecture this thesis aims to explore the integration of public leisure and educational amenities while making the research of the Farm apparent. The remade Experimental Farm will perform a new role of regenerating Canada's high standards of scientific reputation and connecting people with the research process. 


\section{ACKNOWLEDGEMENTS}

Thank you to my advisor, Paul Kariouk, for your persistence and motivation. Your guidance helped transform what was initially an intimidating project into a satisfying and meaningful thesis.

To all the wonderful people at Make It Green Garden Centre, thank you for rooting my knowledge over the summers.

To my parents and grandparents, thank you for your incredible support. You have taught me to care for all living things, and instilled your deep fascination with nature in me.

I could not have done this without you being there for me every step of the way. 


\section{TABLE OF CONTENTS}

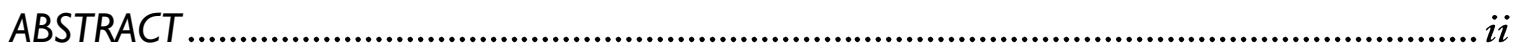

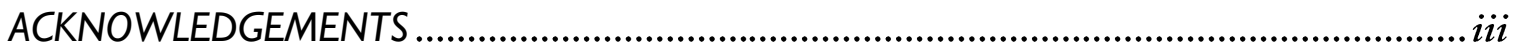

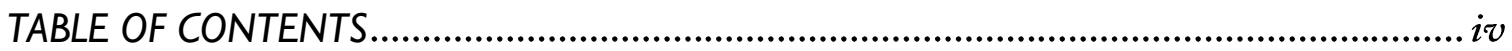

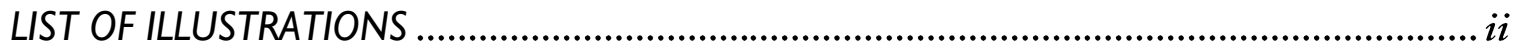

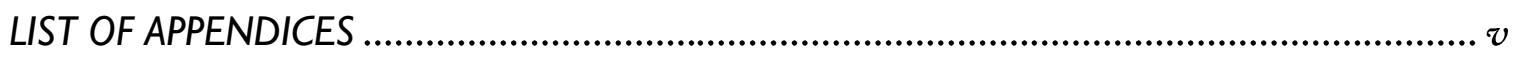

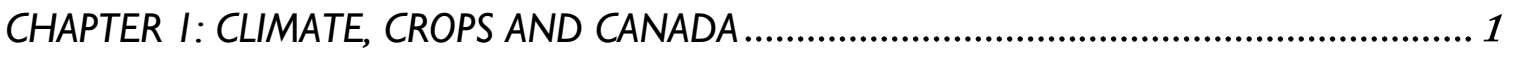

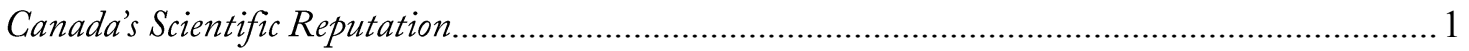

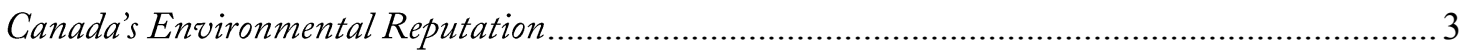

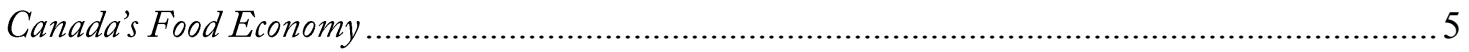

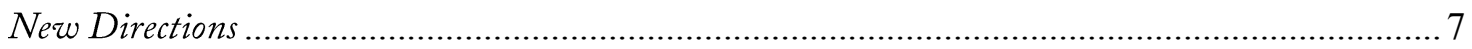

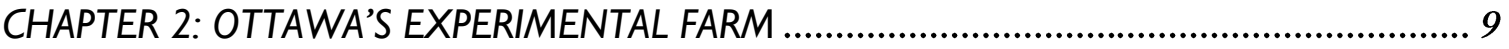

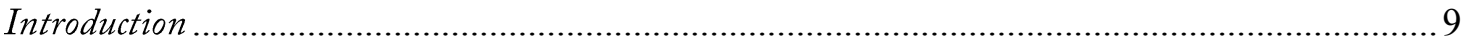

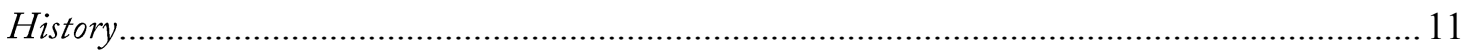

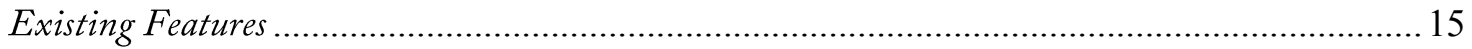

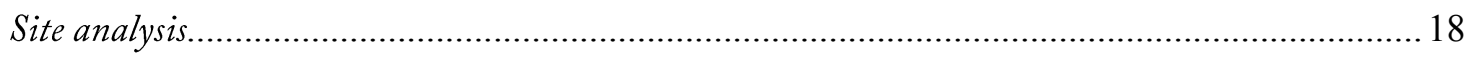

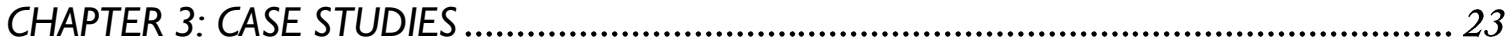

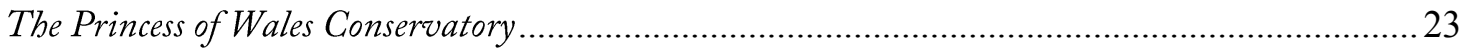

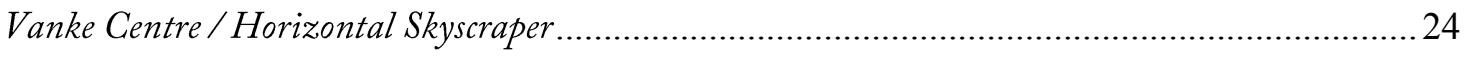

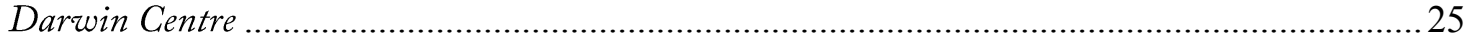

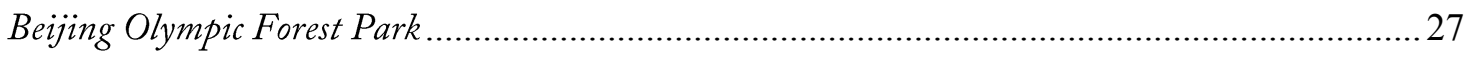

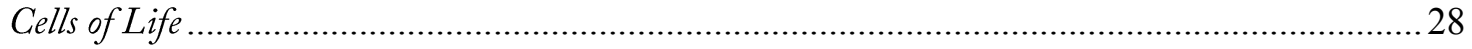

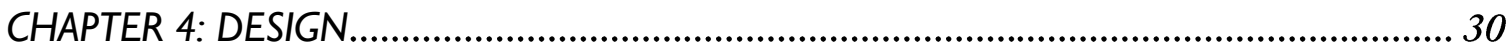

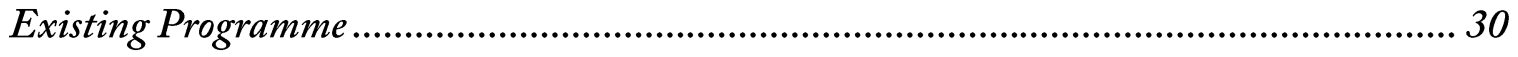

Proposed Programme ...................................................................................................... 31

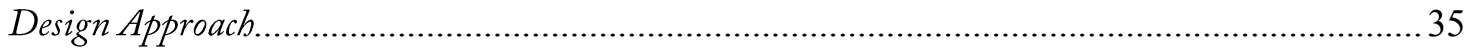


CHAPTER 5: CONCLUSION ....................................................................................... 49

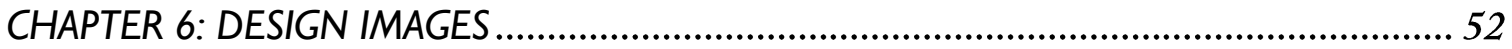

APPENDICES …

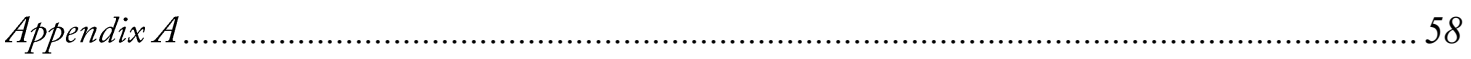

A.1 Intensity Duration Frequency Chart for Ottawa ………………………………....58

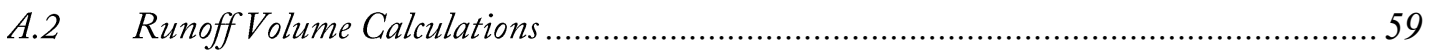

A.3 Annual Rainfall Calculations.............................................................................. 61

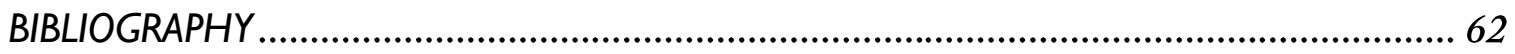




\section{LIST OF ILLUSTRATIONS}

\section{CHAPTER 2: INTRODUCTION}

Illustration 1 Total urban area of Ottawa, 2014............................................................ 9

Illustration 2 Existing (2014) and historic (1941) urban areas of Ottawa.......................... 9

Illustration 3 Existing Experimental Farm Programme................................................ 14

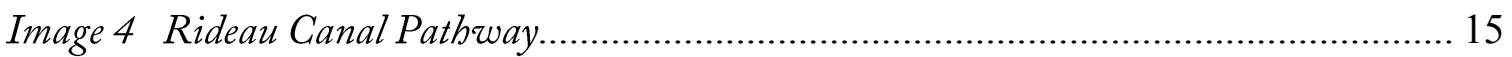

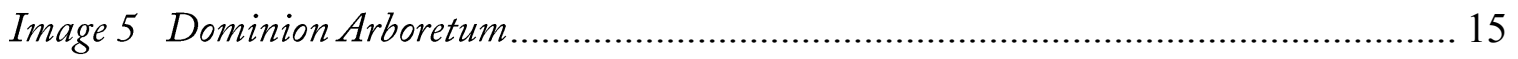

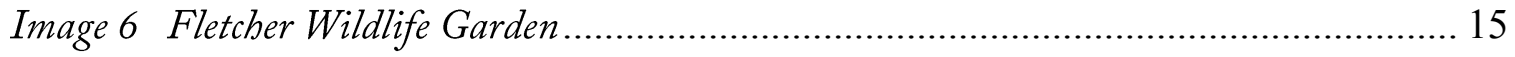

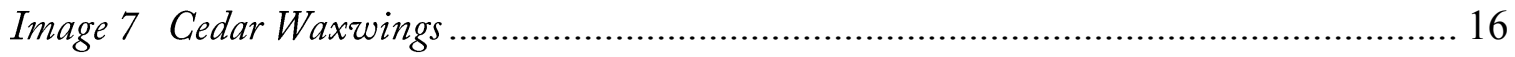

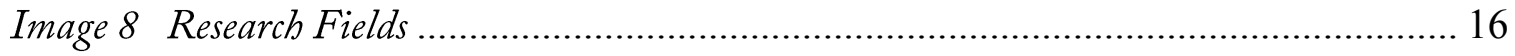

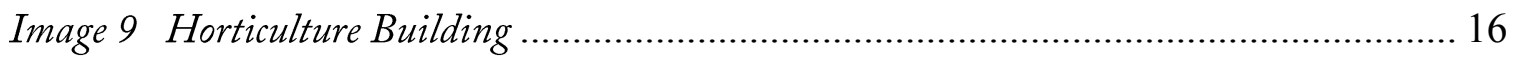

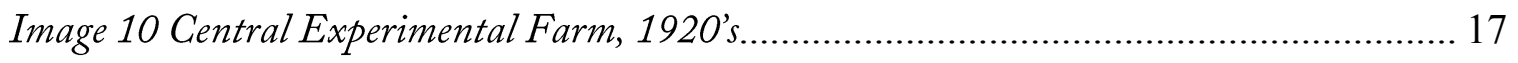

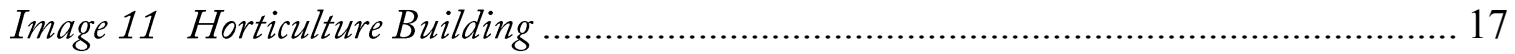

\section{CHAPTER 2: SITE ANALYSIS}

Illustration 12 Neighbourboods surrounding the Farm ................................................. 18

Illustration 13 Densities and distances around the Farm ............................................... 18

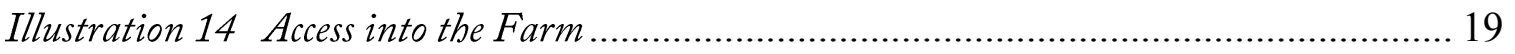

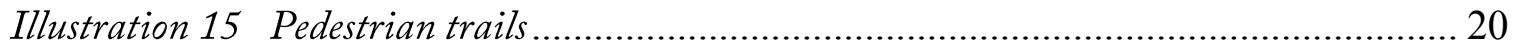

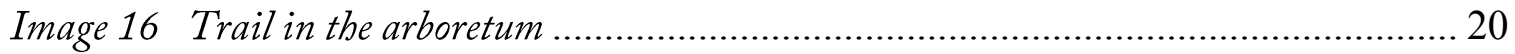

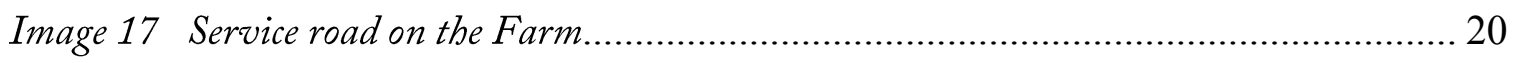

Illustration 18 Vebicular transportation and transit .................................................... 21

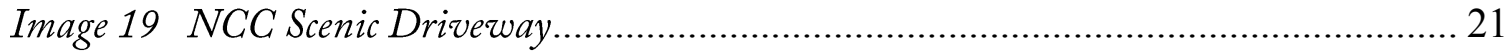

\section{CHAPTER 3: CASE STUDIES}

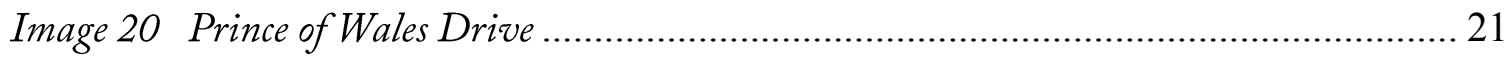

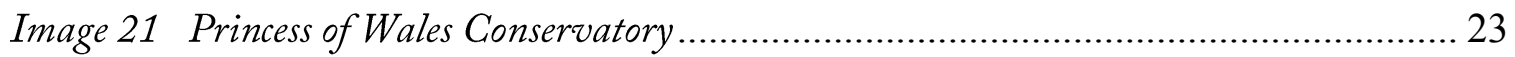

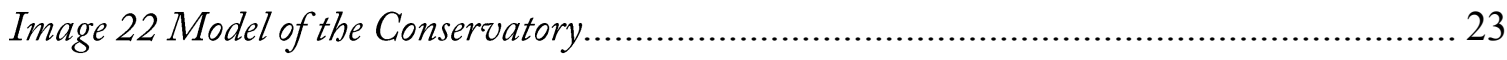




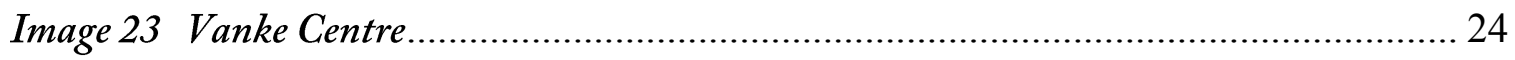

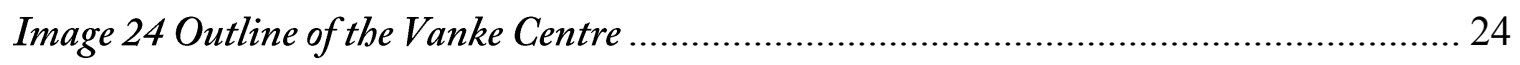

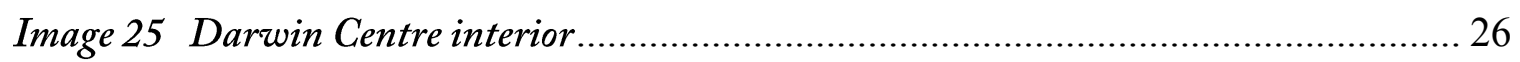

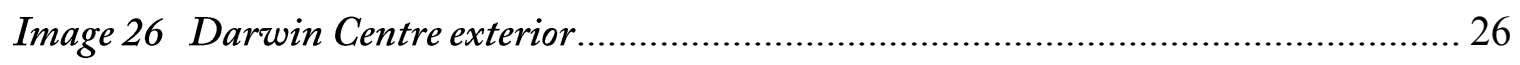

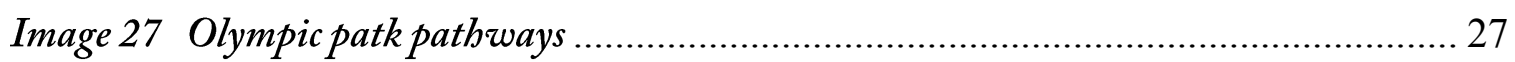

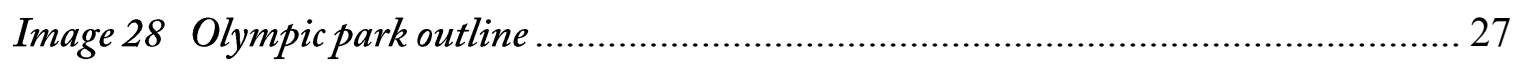

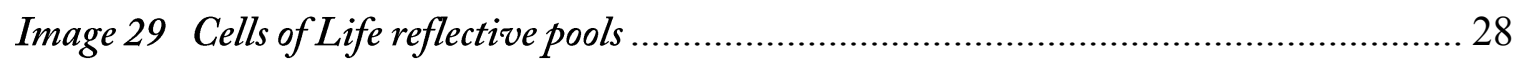

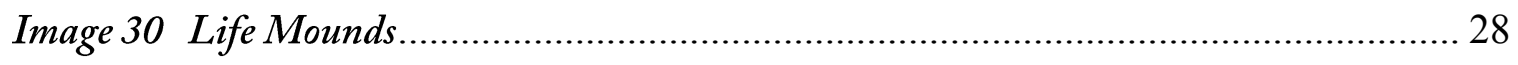

\section{CHAPTER 4: DESIGN}

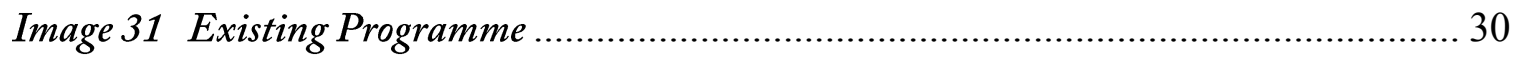

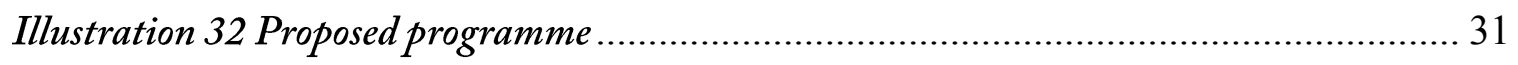

Illustration 33 Research facilities location .................................................................... 32

Illustration 34 Visitor's Centre location........................................................................ 32

Illustration 35 Urban forest locations .......................................................................... 32

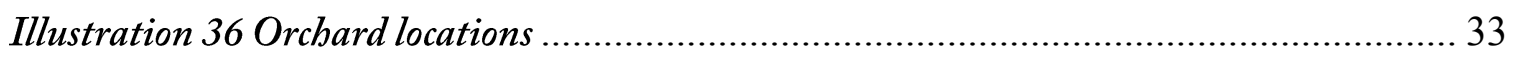

Illustration 37 Community Garden location ………………………………………...... 33

Illustration 38 Water Management System ……………………………………....... 33

Illustration 39 Land bridge locations ............................................................................ 34

Illustration 40 Original and proposed topography section …………………………....... 35

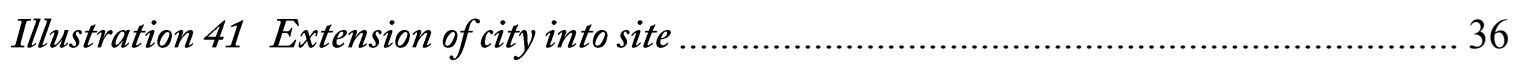

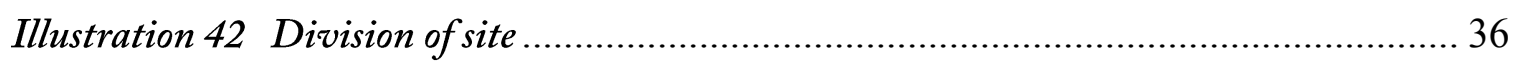

Illustration 43 Pedestrian trails and access points .......................................................... 37

Illustration 44 Raising and lowering of edges................................................................. 37

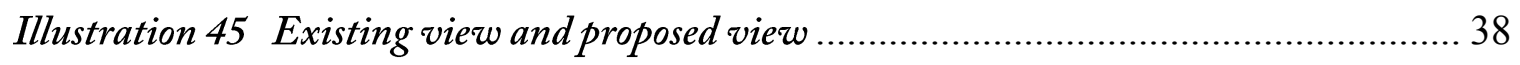

Illustration 46 Existing sound and proposed buffer ........................................................ 38

Illustration 47 Existing wind and proposed buffer........................................................ 38 
Illustration 48 Existing water and proposed collection method........................................ 38

Illustration 49 Built edge and grown edge typology ...................................................... 39

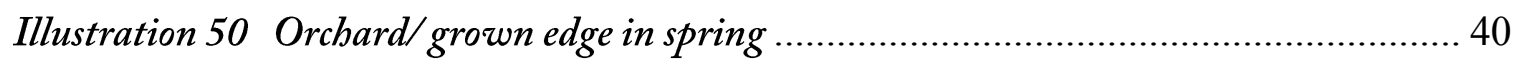

Illustration 51 Research edge/ break in built edge ...................................................... 40

Illustration 52 Section through visitor's centre and research facility ................................. 42

Illustration 53 Research facility and public recreation path ........................................... 42

Illustration 54 Section parallel to Merivale Road showing built and grown edge .............. 43

Illustration 55 Seasonal wind direction and strength ................................................ 43

Illustration 56 Sections through grown edge and land bridges ....................................... 44

Illustration 57 Sections through grown edge and land bridges ....................................... 45

Illustration 58 Sections through grown edge and land bridges ....................................... 45

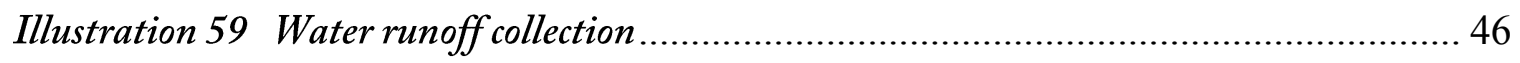

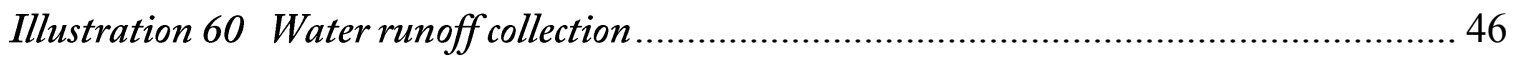

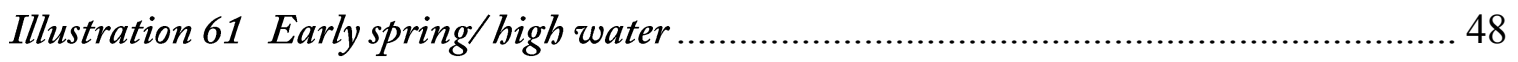

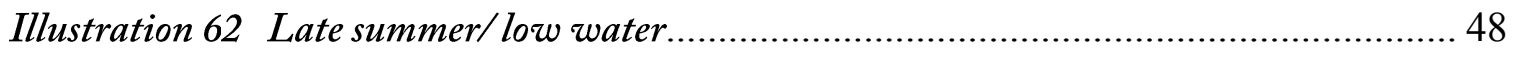

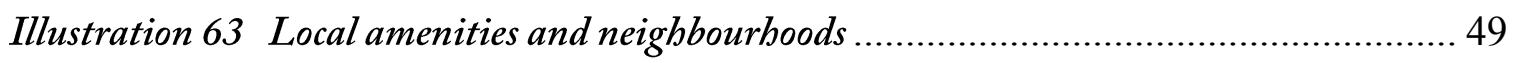

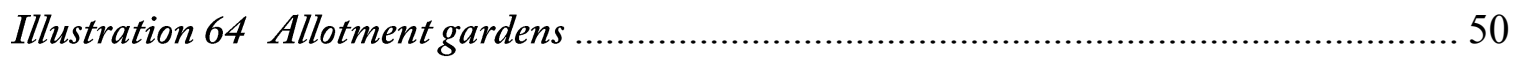

\section{CHAPTER 6: DESIGN IMAGES}

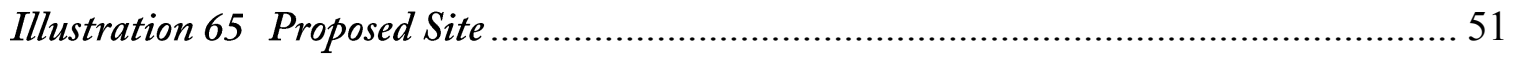

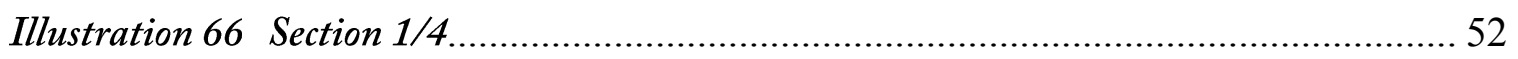

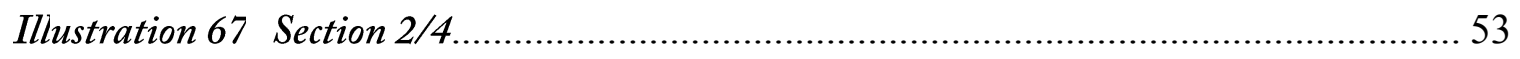

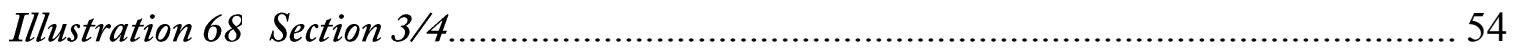

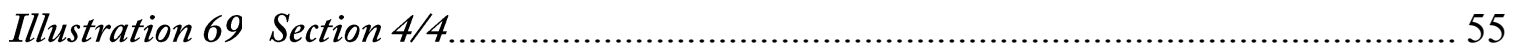




\section{LIST OF APPENDICES}

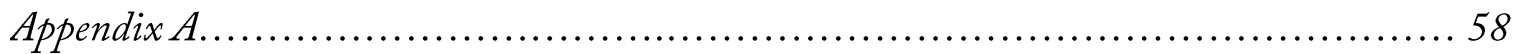

A.1 Intensity Duration Frequency Chart for Ottawa .............................58

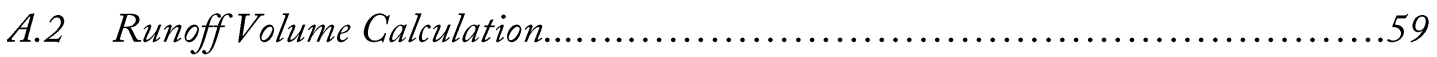

A.3 Annual Rainfall Caıculations............................................61 


\section{CHAPTER I: CLIMATE, CROPS AND CANADA}

\section{Canada's Scientific Reputation}

Canada has endangered its reputation as a leading country for open scientific research following a decade of extensive funding cuts to federal science programmes and implementing government policies that 'muzzled' scientists. Much of the damage to Canada's scientific reputation has occurred at a government policy-making level, however, it is also apparent in the treatment of federal scientific land and buildings discussed in the following chapters.

In 2004 the Office of the National Science Advisor was established as an independent office to provide expert advice to the Prime Minister on all topical science matters from climate change to nanoparticles to space exploration. The government then used the information provided by the office to inform their decisions, such as forming policies for reducing emissions to meet with the Kyoto Protocol.

The subsequent government, attempting to cut budgets, merged the Office of the National Science Advisor into Industry Canada, shifting away from scientific goals and focusing scientists' efforts on the economy. In 2008, the office was abolished. ${ }^{1}$ The government's involvement appeared to be limiting scientists to commercially-applicable research that

\footnotetext{
${ }^{1}$ Mancini, Melissa. "Science Cuts And Muzzling In Canada: How Conservatives Reshaped A Discipline." The Huffington Post Canada, April 30, 2015. Accessed January 4, 2015. http://www.huffingtonpost.ca/2013/04/30/science-cuts-muzzlingcanada-conservatives_n_3112348.html.
} 
would generate jobs rather than scientific insight. ${ }^{2}$ The focus on 'innovation' (improving an existing method) over 'discovery' (adding to scientific knowledge) is reflected, for example, in the government's grants to universities, with more money funding programmes to innovate the extraction of fossil fuels than experimental research on climate change in the oceans. While budget cuts for scientists are less apparent than cuts for health care and other social programmes, the cuts and muzzling has hurt Canada's reputation for open-research and scientific discovery.

Interviews with scientists and former politicians support evidence that scientists were stifled if the government thought the findings would be viewed in a negative manner. ${ }^{3}$ Canadian scientists have been unable to communicate with the public through media without consent from government officials. As a result, journalists became frustrated with the need to gain consent and stopped trying to interview federal scientists. Most federal scientists feared an intervention from their departments if they were to share a concern with the public regarding health and safety or a threat to the environment without first gaining consent to speak. ${ }^{4}$ The lack of published scientific work formed a barrier between scientists and the general public, particularly in areas that did not directly translate to economic gain. Federal scientists are funded by Canadian taxpayers, however, if research goes unpublished it fails to reach the public. If a government decision is disputed by scientific research, public support for the

\footnotetext{
2 Birchard, Karen, and Jennifer Lewington. "Dispute Over the Future of Basic Research in Canada." The New York Times, January 16, 2014, Americas sec. Accessed January 4, 2015. http://www.nytimes.com/2014/02/17/world/americas/disputeover-the-future-of-basic-research-in-canada.html?ref=canada\&_r=0.

${ }^{3}$ Mancini, Melissa. "Science Cuts And Muzzling In Canada: How Conservatives Reshaped A Discipline." The Huffington Post Canada, April 30, 2015. Accessed January 4, 2015.

${ }^{4}$ Jolley, Rachael. "Cuts and Red Tape Are Gagging US and Canadian Science." New Scientist, April 9, 2014.
} 
government would decline. Keeping the public in the dark about certain issues and focusing on research that innovates an industry or supports an action keeps the public in support of such a government's decisions.

At the time of this writing, the muzzling of scientists is in remission under a new government. The latest government states that it will 'value science and treat scientists with respect,' aiming to ensure that government science is fully available to the public and that scientists are able to speak freely about their work to the media. ${ }^{5}$ While written policies for open research can be altered to promote scientific discovery and public knowledge, these changes can be seen physically in the treatment and design of research buildings and how they engage the general public.

\section{Canada's Environmental Reputation}

Canadians pride themselves on promoting an image of a country that advocates human rights, the environment, and keeping the peace. The impression of Canada as the pristine north has been in question for many years as events and actions have been brought to light, most notably backing out of the Kyoto Protocol.

The Kyoto Protocol was the first binding global agreement to reduce greenhouse emissions. Canada ratified the protocol in 2002, which required Canada to reduce greenhouse emissions

\footnotetext{
5 "Science and Scientists." Liberal Party of Canada. Accessed January 4, 2016. http://www.liberal.ca/realchange/scienceand-scientists/\#0.
} 
to 6\% below 1990 levels. In 2002, Canada's emissions were 20\% above 1990 levels. ${ }^{6}$ To meet the requirements of the Protocol, the Canadian government at the time developed an extensive plan to cut emissions. The government established several new departments including the Wind Power Production Incentive and the Energuide for Houses to research alternative power sources and provide incentive for Canadians to save energy at home, and planned to fund provinces and municipalities for energy-saving infrastructure projects. ${ }^{7}$ Although the plan was only a fraction of what Canada needed to accomplish to meet its goals, signing the agreement and attempting change was at least a public acknowledgement of these dire issues.

Under a Conservative government, funding was cut to many of the incentive programmes and in 2011 Canada became the first country to back out of the Kyoto protocol. When Canada intensified tar-sands production, the predicted rise in greenhouse emissions were well beyond what the government could cope with. ${ }^{8}$ Many Canadians feel passionate about the environment and were dismayed when Canada backed out, particularly when months later the United States committed to more stringent emission cuts. ${ }^{9}$

The United Nations Paris Climate Conference, held in December 2015, provides Canada a second chance at tackling climate change. The goal of the conference was for countries to

\footnotetext{
${ }^{6}$ Young, Emma. "Canada Ratifies Kyoto Protocol." New Scientist, December 17, 2002.

7 "Canada and the Kyoto Protocol." David Suzuki Foundation. Accessed January 5, 2016. http://www.davidsuzuki.org/issues/climate-change/science/canada-climate-change/canada-and-kyoto/.

${ }^{8}$ Walsh, Bryan. "Bienvenue Au Canada: Welcome to Your Friendly Neighborhood Petro-State." Time, December 11, 2011.

${ }^{9}$ Prystupa, Mychaylo. "Canada Should Re-ratify Kyoto, Says Elizabeth May." National Observer, November 28, 2015, News sec. Accessed January 5, 2015.
} 
agree to limit global warming to 2 degrees Celsius, half of the predicted temperature of 4 degrees Celsius if greenhouse emissions continued at its current rate. For Canada to discuss combating global warming at a conference in a positive manner was a major change from the reluctant attitudes of previous Canadian governments. However, Stephen Lewis, Canada’s former ambassador to the United Nations, warned that simply talking about climate change is no good unless the Canadian government can mirror its goals in its own policies. ${ }^{10}$ If Canada is to uphold its new goals on reducing the effects of climate change, the country must quickly implement new policies, incentives and research towards innovation, invention and discovery.

\section{Canada's Food Economy}

Farming is highly dependent on climate; changes to weather patterns and rising temperatures is affecting growing conditions and yields. While agriculture is affected by global warming, it is also a major contributor of greenhouse gasses from animal husbandry, deforestation, petroleum-based fertilisers and biomass burning. Up to $30 \%$ of global greenhouse emissions of carbon dioxide, methane and nitrous oxides are produced from farming. ${ }^{11}$ However, much of the focus on reducing greenhouse gas emissions has been from other sectors such as

\footnotetext{
${ }^{10}$ Mandel, Charles. "Canada's Remarkable Turn-around on Climate Needs to Be Backed by Policy: Stephen Lewis." National Observer, December 8, 2015, News sec. Accessed January 5, 2016. http://www.nationalobserver.com/2015/12/08/news/canadas-remarkable-turn-around-climate-needs-be-backed-policystephen-lewis.

11 "AGRICULTURE." Agriculture and Climate Change. Accessed January 5, 2016. http://www.climate.org/topics/agriculture.html.
} 
transportation, energy and forestry. ${ }^{12}$ As the earth's population continues to increase and climate change progresses, the methods of food production will need to adapt. The global food system must adapt to suit local changing climates, populations and land-use patterns instead of focusing on the highest-value crop or a generalised emission-reducing farming method that may not be effective for all sites.

In Canada, agriculture amounts to $10 \%$ of national carbon emissions. ${ }^{13}$ Improved management of farmland will reduce greenhouse gas emissions and also improve water, air and soil quality.

The 'green revolution' that occurred after World War II in North America led to greater production of food using less land and fewer people due to the introduction of chemical fertilisers, new farm machinery and automated processing methods. Farmers began to specialise in crops, abandoning traditional methods of crop rotation. With the use of chemical fertilisers and machinery, farmers could employ fewer people to work more land. With the low price of fuel and improved infrastructure, cities could import their food from more distant farms and even other countries. By favouring chemical soil amendments, pesticides and fertilisers, soil health has declined, resulting in damaged ecologies and biomass dilution - the loss of nutrition in food. Farmers receive more income from feeding cattle and producing ethanol than feeding people directly. Only a small percentage of farmers grow

\footnotetext{
${ }^{12}$ Smith, P., et al. 2007: Agriculture. In Climate Change 2007: Mitigation. Contribution of Working Group III to the Fourth Assessment Report of the Intergovernmental Panel on Climate Change [B. Metz, O.R. Davidson, P.R. Bosch, R. Dave, L.A. Meyer (eds)], Cambridge University Press, Cambridge, United Kingdom and New York, NY, USA. Page 499.

${ }^{13}$ Smith, P., et al. Page 524
} 
food for people - instead cities rely on cheap fuel to import produce grown in rural areas or in other countries, adding to the total carbon emissions of the global food economy.

Today's global food economy, based on chemical agriculture and commercial monoculture farming, has led to an unsustainable demand from the earth. Monoculture farming may be efficient economically but does not support the long-term health of the food system or environment.

In recent years the desire to support alternative food sources has risen with an increased awareness of the inefficiencies in the conventional global food system. As populations continue to rise, responsible land management is becoming an increasingly important topic. Alternative farming methods, such as local or urban farms, have the potential to revive ecologies through responsible land and water management. The resurgence of farmer's markets and the multiplicity of local food products are an indication that people are caring more about where their food comes from and are looking for sustainable alternatives to the global food economy.

\section{New Directions}

The human impact on the environment is of great concern as populations increase and climate change intensifies. Reducing the impact of polluting activities, such as agriculture, is vital to supporting the population and reducing impact on the environment. While research on climate change and agriculture is ongoing, if the knowledge cannot be readily shared beyond the scientific community its impact is minimal. Distributing scientific knowledge to 
the general public is essential for wide-spread action towards reducing the effects of climate change.

This thesis proposes that the thoughtful design of research facilities has the potential to engage and influence the public directly, imparting knowledge with a more diverse section of the society. When designed with the needs of the general public in mind, scientific facilities can showcase current research, engage the local community and educate the visitor on effective and environmentally-conscious practices. If members of the public can become engaged in the research process and witness the effects, they are likely to share a positive view towards climate science, develop an encouraging relationship with scientists and will more readily adopt new techniques and processes towards reducing overall environmental impact. 


\section{CHAPTER 2: OTTAWA'S EXPERIMENTAL FARM}

\section{Introduction}

Ottawa's Central Experimental Farm represents the country's commitment to researching sustainable agricultural practices. While the government is now aiming to promote an open and honest attitude towards federal research, this attitude is only seen through policies and does not appear on the site.

The Farm occupies a sizable, prominent area in urban Ottawa, easily identified by its rural appearance. The site researches agricultural topics of national priority, including environmentally-conscious farming practices. The Farm operates $27,000 \mathrm{~m} 2$ of laboratories, $2,300 \mathrm{~m} 2$ of greenhouses and $4.25 \mathrm{~km} 2$ of field plots ${ }^{14}$. The area also houses the Canadian Museum of Food and Agriculture, 18 acres of the Fletcher Wildlife Garden and 60 acres of the Dominion Arboretum.
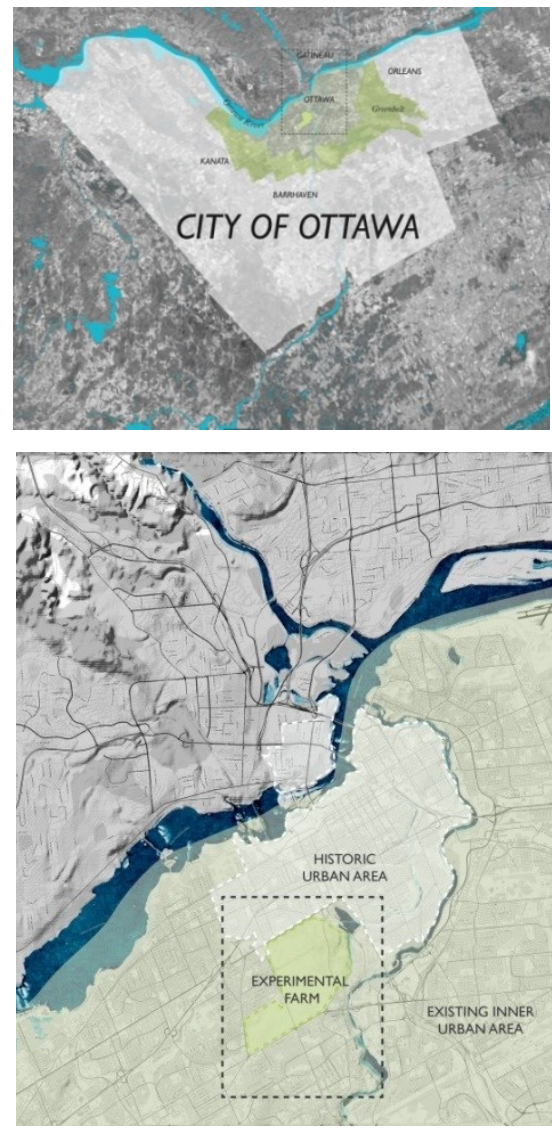

Illustration 1 Total urban area of Ottawa, 2014 Illustration 2 Existing (2014) and historic (1941) urban areas of Ottawa.

\footnotetext{
${ }^{14}$ Facts, Figures and Facilities, "Ottawa Research and Development Centre." ECORC;Agriculture and Agri-Food Canada;Government of Canada. November 24, 2015. Accessed January 2, 2016. http://www.agr.gc.ca/eng/science-andinnovation/research-centres/ontario/ottawa-research-and-development-centre/?id=1180546650582.
} 
Unfortunately, the Farm's location in the city is undervalued. The site is considered impractical for conducting government research, with many members of the public arguing that the research should be relocated outside the city and the Farm turned into a 'typical' city function such as parkland or housing. The rural appearance of the site, its proximity to downtown Ottawa and its adjacency to major transport routes make the Farm attractive for developers.

For over 100 years, the Experimental Farm has researched the intertwining of climate and agriculture. As global temperatures rise, the research conducted on the Farm is as critical as ever. By adding more diverse public programming and engaging the public with the research, the Farm can acquire a new role by connecting the residents of Ottawa to the latest scientific studies. The Farm can become a symbol of Canada's scientific and environmental commitments through research and education in agriculture.

Rather than develop the site into a new city neighbourhood, this thesis argues that the site's prominent location should be used to highlight research on agriculture and climate change. While the Experimental Farm is currently used for testing crops for rural conditions, the Farm's unique urban conditions would make it suitable for testing crops for urban food production, including testing greenhouse and rooftop conditions. The Farm's urban location also serves as a connection between the scientific community, ecological systems, and the general public that live in and visit the area. Incorporating diverse public programming will increase the appeal of the site to all members of the public. The bridging of programming 
can create a landscape of discovery for all ages, from formal exhibitions on active research to wandering through open-air galleries of crops to witnessing the local wildlife and the shifts of the seasons. A site that welcomes the public and captivates them with a dynamic landscape will keep the Experimental Farm in the public eye.

\section{History}

Established in 1886, the Central Experimental Farm has been a site of continuous research for rural agricultural practice. The Experimental Farm Station Act of 1886 marked the beginning of a national agriculture research programme aimed to improve the lives of those who worked off the land. At the time, the majority of Canada's population was dependant on the land for survival. To ensure Canada's future prosperity it was in the interest of the government to invest in natural resources to establish a stronger Canadian agricultural economy and benefit people who worked the land. An experimental farm was located in each of Canada's main climates to research agricultural practices for that zone. Stations were established in Nova Scotia, Manitoba, North-West Territories, British Columbia and Ontario-Quebec. Ottawa was chosen as the location for the central research station for its soils and climate representing an average of the country and its proximity to Parliament. The acquired 465 hectares $\left(4.65 \mathrm{~km}^{2}\right)$ land was several kilometres from Parliament and beyond the limits of the city at the time.

Although the land was previously farmland, the site was graded and cleared further to meet the needs of the research fields, gardens and buildings. Woodlands along the north and west 
edges of the Farm were established as a buffer against winter winds to prevent soil erosion, as well as the tree-lined service roads that crossed the site.

The Farm was soon an essential element of the Ottawa landscape, likened to a national park or romantic pastoral landscape. An early account of the site describes that from the highest elevation 'one gets a charming view of the city... while to the northwest the Hull mountains loom up in all the grandeur of their hazy blue.' ${ }^{15}$ It was also connected to the flow of goods in the city, using ash from the wood-heated government buildings as fertiliser and auctioning its harvests to the public. ${ }^{16}$ The Farm's research departments covered a broad spectrum of agriculture and related industries, from forestry management methods to ornamental plant cultivation to overwintering fruit trees.

In the 1930 's, the Farm was integrated into the National Capital's scenic driveway plan. ${ }^{17}$ The driveways introduced more people to the Farm as they passed through, however the widening of the Farm's roads resulted in significant loss of the sheltering woodlands along the north and west boundaries of the site.

\footnotetext{
${ }^{15}$ Smith, Helen, and Mary Bramley. Ottawa's Farm: A History of the Central Experimental Farm. Burnstown, Ont.: General Store Pub. House, 1996. Page18

${ }^{16}$ Smith, Helen, and Mary Bramley. Ottawa's Farm: A History of the Central Experimental Farm. Burnstown, Ont.: General Store Pub. House, 1996. Page 19

17 "Central Experimental Farm National Historic Site Management Plan (4 of 20)." Central Experimental Farm Integrated Services;Agriculture and Agri-Food Canada;Government of Canada. May 08, 15. Accessed March 16, 2016. http://www.agr.gc.ca/eng/about-us/offices-and-locations/central-experimental-farm/about-thecentral-experimental-farm/central-experimental-farm-national-historic-site-management-plan-1-of20/central-experimental-farm-national-historic-site-management-plan-4-of-20/?id=1170421393729.
} 
The Farm became a National Historic Site in 1998. It was designated based on: its distinctiveness as a cultural landscape; a site of ongoing scientific research since 1889; its reflection of $19^{\text {th }}$ century landscape philosophy; its symbolism of the central role of agriculture in shaping Canada and; its uniqueness as a farm within a city. ${ }^{18}$

As the city has expanded around the Farm, it is seen more as an anomaly in the city.

However, many see the Farm as a welcome change in scenery from the surrounding urban and sub-urban environment. ${ }^{19}$

The Experimental Farm's continuation as a scientific research centre is now uncertain as parcels of the Farm have been sold to developers for housing. Agriculture Canada announced that 60 acres of land were to be leased for an expansion to the Ottawa Civic Hospital. While some members of the public were happy that what seemed to be vacant land was finally being put to use, others were distraught at the potential loss of nationally historic land and the open, park-like space. ${ }^{20}$

If the Farm is to resist development proposals, the land should reflect the diversity of research and present topics relevant to a contemporary, urban public.

\footnotetext{
18 "Central Experimental Farm National Historic Site Management Plan (5 of 20)." Central Experimental Farm Integrated Services;Agriculture and Agri-Food Canada;Government of Canada. March 13, 2013. Accessed January 6, 2016. http://www.agr.gc.ca/eng/about-us/offices-and-locations/central-experimental-farm/about-the-central-experimentalfarm/central-experimental-farm-national-historic-site-management-plan-1-of-20/central-experimental-farm-nationalhistoric-site-management-plan.

${ }^{19}$ Smith, Helen, and Mary Bramley. Ottawa's Farm: A History of the Central Experimental Farm. Burnstown, Ont.: General Store Pub. House, 1996.Page 121

${ }^{20}$ Spears, Tom. "Explained: What Actually Happens at the Experimental Farm." Ottawa Citizen, November 13, 2015, Local sec. Accessed 2016.
} 


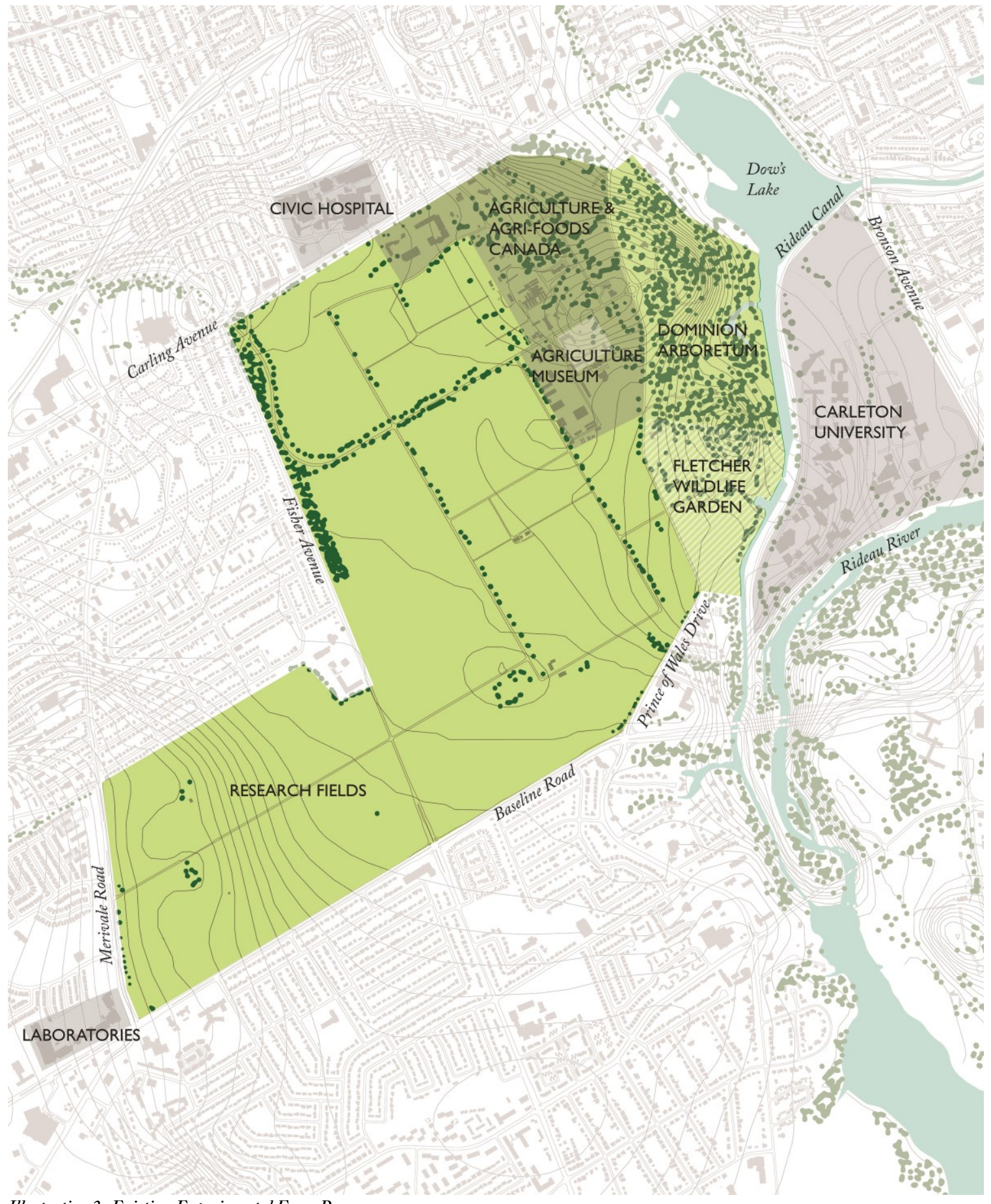

Illustration 3 Existing Experimental Farm Programme 


\section{Existing Features}

\section{Dominion Arboretum}

Today the most popular area of the site is the

Arboretum, intended to showcase deciduous and

evergreen trees and shrubs tolerant of Canadian winters.

Adjacent to the Rideau Canal, it is a popular spot for

tourists and residents year-round, with numerous

picturesque trails and look-out points over the city.

Much of the Arboretum is located on a sheltered slope,

creating a micro-climate for trees that would be

otherwise unable to withstand the harsh winter winds.

The ornamental gardens adjacent to the arboretum are

maintained as they were in the early 1900's.

\section{Fletcher Wildlife Garden}

Adjacent to the Arboretum, the Fletcher Wildlife

Garden was established to attract wildlife to the Farm.

The 18 acre, low-maintenance garden occupies a small

ravine at the south end of the arboretum and contains a

variety of habitats, including open fields, mature woods

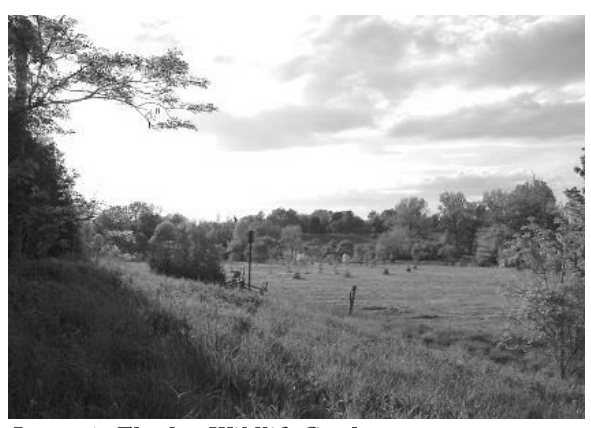

Image 6 Fletcher Wildlife Garden

Steven Higgins / CC BY - NC 2.0

and dense thicket. The garden is a popular location 
for wildlife enthusiasts, where various species of

butterflies, birds and amphibians. The arboretum and

wildlife garden are maintained by the Friends of the

Farm, a volunteer-based charity dedicated to keeping the

Farm open to the public.

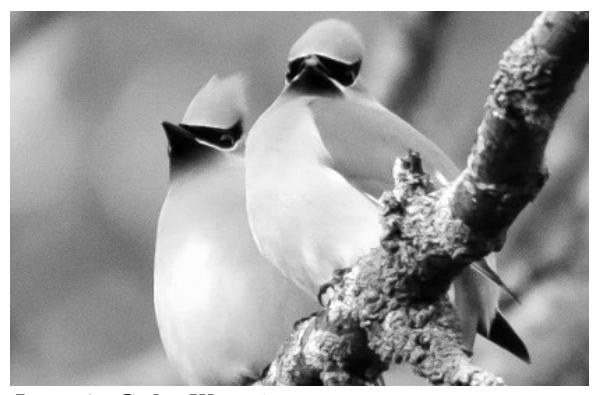

Image 7 Cedar Waxwings

Brent Eades / CC BY-NC ND 2.0

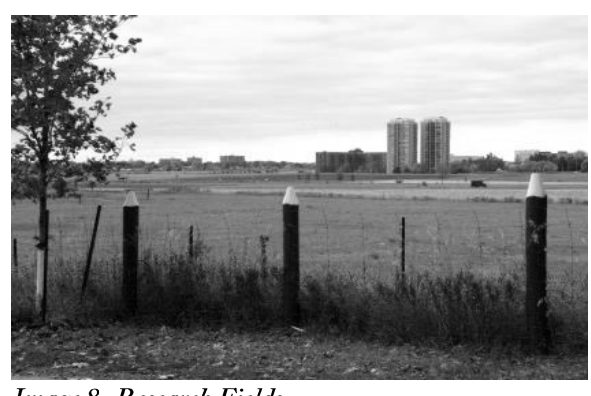

Image 8 Research Fields

Photo by author

readily available. The research fields cover $80 \%$ of the

total area of the Farm.

\section{Agriculture and Agri-Foods Canada}

The historic buildings are used as offices for several

government departments, including Natural Resources

Canada and Agriculture and Agri-Foods Canada. Prior

to the Farm's historic designation, many of the original

dwellings, office buildings and greenhouses have been

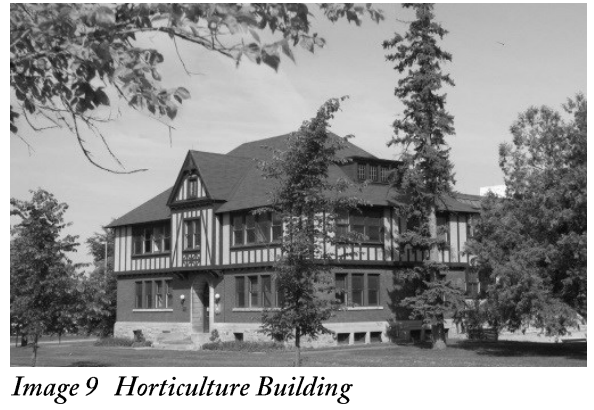

Image 9 Horticulture Building

M. Manske/CCO 
demolished and replaced with modern facilities, concentrated in the laboratories at Baseline and Merivale Roads. While Agriculture Canada has cut several departments from the Experimental Farm, including forestry and horticulture, the laboratories and genetic research departments are expected to keep growing. ${ }^{21}$

\section{Agriculture Museum}

The Canada Food and Agriculture Museum is a modest facility focusing on describing the history of agriculture in Canada. While the Farm no longer researches animal husbandry and breeding programmes, the petting zoo at the museum continues the tradition in a model working-

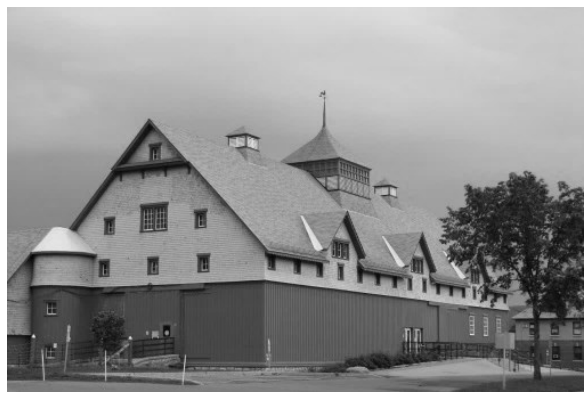

Image 11 Horticulture Building farm environment. The museum is managed by the Canadian Science and Technology Museums Corporation who also manage the Canada Space and Aviation Museum and the Canada Technology Museum.

\footnotetext{
${ }^{21}$ Smith, Helen, and Mary Bramley. Ottawa's Farm: A History of the Central Experimental Farm. Burnstown, Ont.: General Store Pub. House, 1996.Page 127
} 


\section{Site analysis}

\section{Neighbourhoods}

The Civic Hospital neighbourhood to the north of the site is classified as a mature neighbourhood and zoned for small infill projects. Fisher Heights along the south edge of the Farm and Carlington to the west are suburban-like in their development, with a few high-rise developments. Any future development will likely occur along Carling Avenue, as it is the least developed section surrounding the Farm.

\section{Planning}

The Experimental Farm is subject to federal, provincial and municipal planning policies.

Overall, the plans aim to promote stronger connections between the levels of government, including beautification of Ottawa, city reforestation projects in Ontario and educating
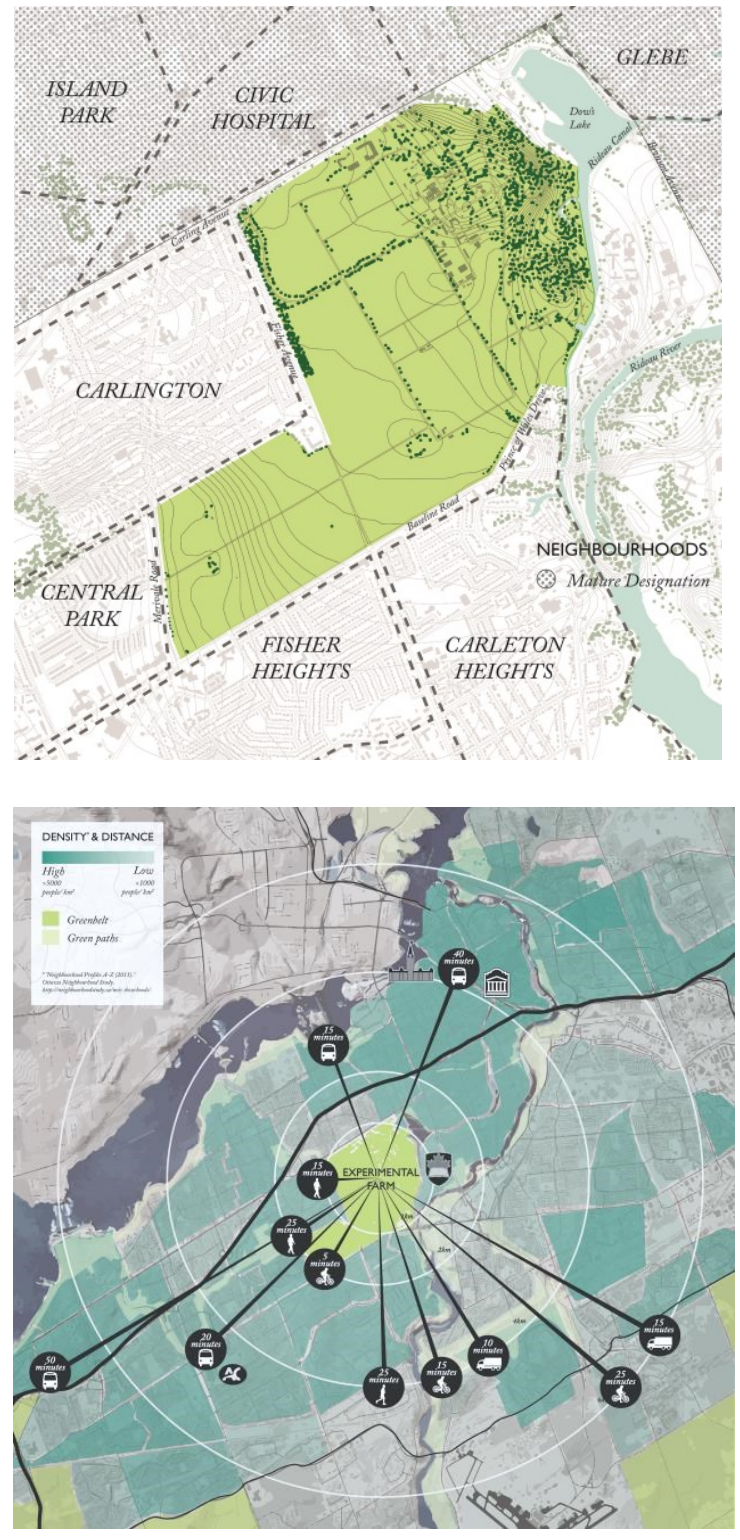

Illustration 12 Neighbourhoods surrounding the Farm Illustration 13 Densities and distances around the Farm 
links between agriculture and the ecosystem across Canada. A summary of the planning policies the key points of the Experimental Farm are: Strengthening the link between the Farm and natural ecosystems; ${ }^{22}$ promoting sustainable design through protecting and improving greenspaces $;{ }^{23}$ preserving the historic buildings on the site $;{ }^{24}$ and improving scientific and technical education in Canada. ${ }^{25}$

\section{Access}

The Dominion Arboretum is accessible by car via

Prince of Wales Drive, or by foot along the

Rideau Canal Western Pathway. Visitors east of the Canal must cross the Canal along major roads at the top and bottom of the site, or cross the narrow Hartwell locks beside Carleton University. The only dedicated pedestrian crossing is at the locks, and the crossing is not universally accessible.

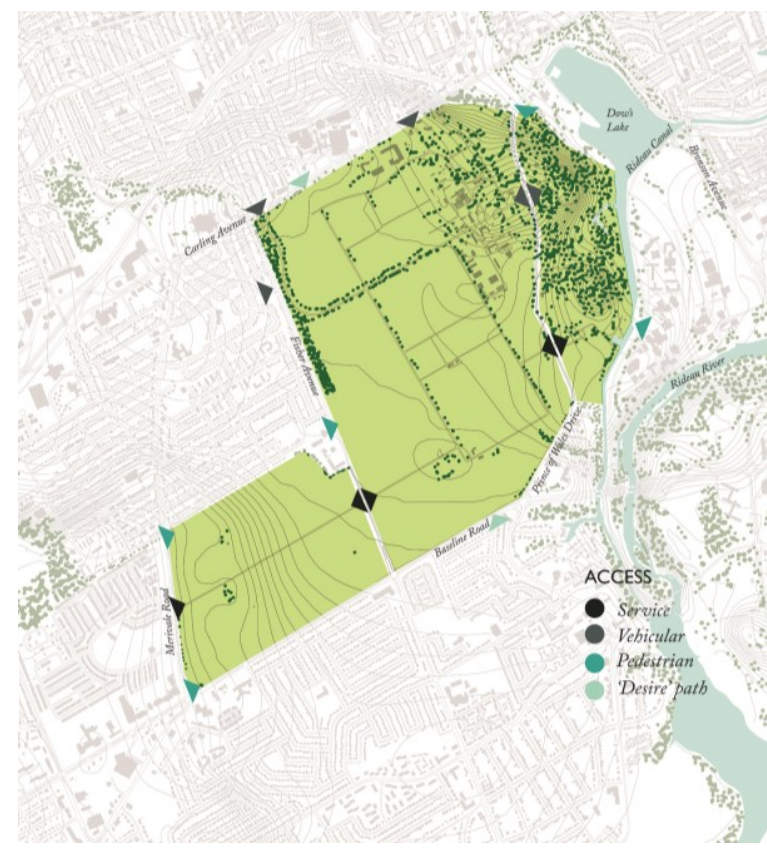

There are extensive pedestrian rails in the

arboretum, however, there is no dedicated

Illustration 14 Access into the Farm

\footnotetext{
22 "2015-16 Report on Plans and Priorities." Agriculture and Agri-Food Canada;Government of Canada. Accessed January 30, 2016. http://www.agr.gc.ca/eng/about-us/planning-and-reporting/reports-onplans-and-priorities/2015-16-report-on-plans-and-priorities/?id=1422918881954.

${ }^{23}$ Sgro, Judy. Canada's Urban Strategy: A Vision for the 21st Century. Ottawa: Prime Minister's Caucus Task Force on Urban Issues, 2002.

24 "Formative Evaluation of the Historic Places Initiative." Parks Canada. Accessed January 30, 2016. http://www.pc.gc.ca/docs/pc/rpts/rve-par/21/3_e.asp.

${ }^{25}$ Canada. Industry Canada. Canada's Innovation Strategy: New Ideas, New Opportunities. Ottawa: Govt. of Canada, 2002.
} 
pedestrian route that connects the arboretum to the rest of the Farm. Pedestrians must use the car access road off the traffic circle to connect to the museum and NCC Scenic Pathway, a problem in the summer during peak visitor season. Pedestrian tracks, or desire lines, can be seen on the ground where pedestrians have made their own access paths on the site.

\section{Trails}

The Experimental Farm Pathway is a pedestrian and bike trail that connects the Farm to multiple bike trails to the west, eventually leading to the Ottawa River and its pathway. The trail runs through several neighbourhoods, and is used by commuters, dog walkers and for recreation.

Smaller trails follow gravel roads and paved service roads within the farm. All of the paths in the arboretum are coarse gravel. The Experimental Farm Parkway and the Rideau Canal Western Pathway are the only paved and accessible routes at the Experimental Farm.

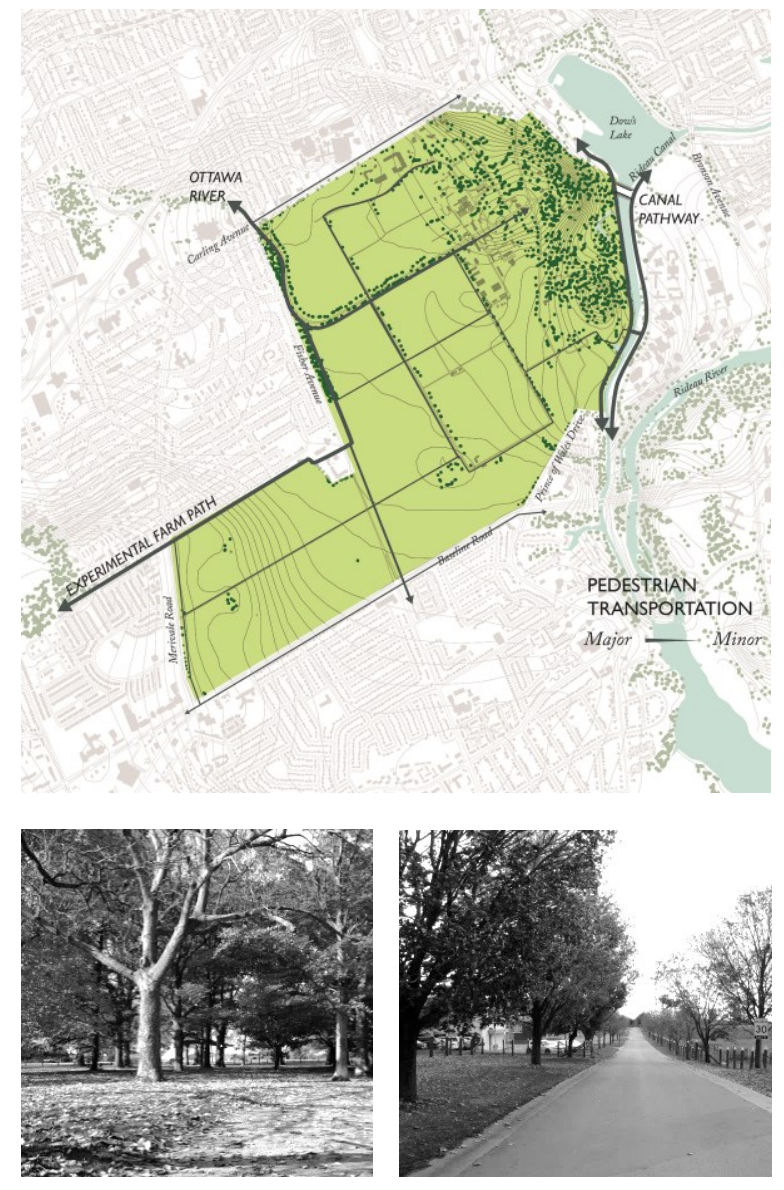

Illustration 15 Pedestrian trails Image 16 Trail in the arboretum Image 17 Service road on the Farm 


\section{Transport}

Baseline Road to the south and Carling Avenue to the north are major transportation arteries, running east-west to connect central Ottawa to the surrounding suburbs. The Civic Hospital is located at the north edge of the site on Carling, while Baseline Road is primarily low-rise neighbourhoods. Merivale Road and Fisher Avenue are secondary roads, running northsouth through Ottawa, and are mixed-use roads consisting of parking lots, malls and varying types of residential buildings.

Prince of Wales Drive is a scenic parkway that follows the Canal up from the south and ends at the top of the site. The National Capital Commission Scenic Driveway is a tree-covered route flanked with bike trails. All of the roads serving the site, with the exception of Prince of Wales Drive, are expected to be widened to
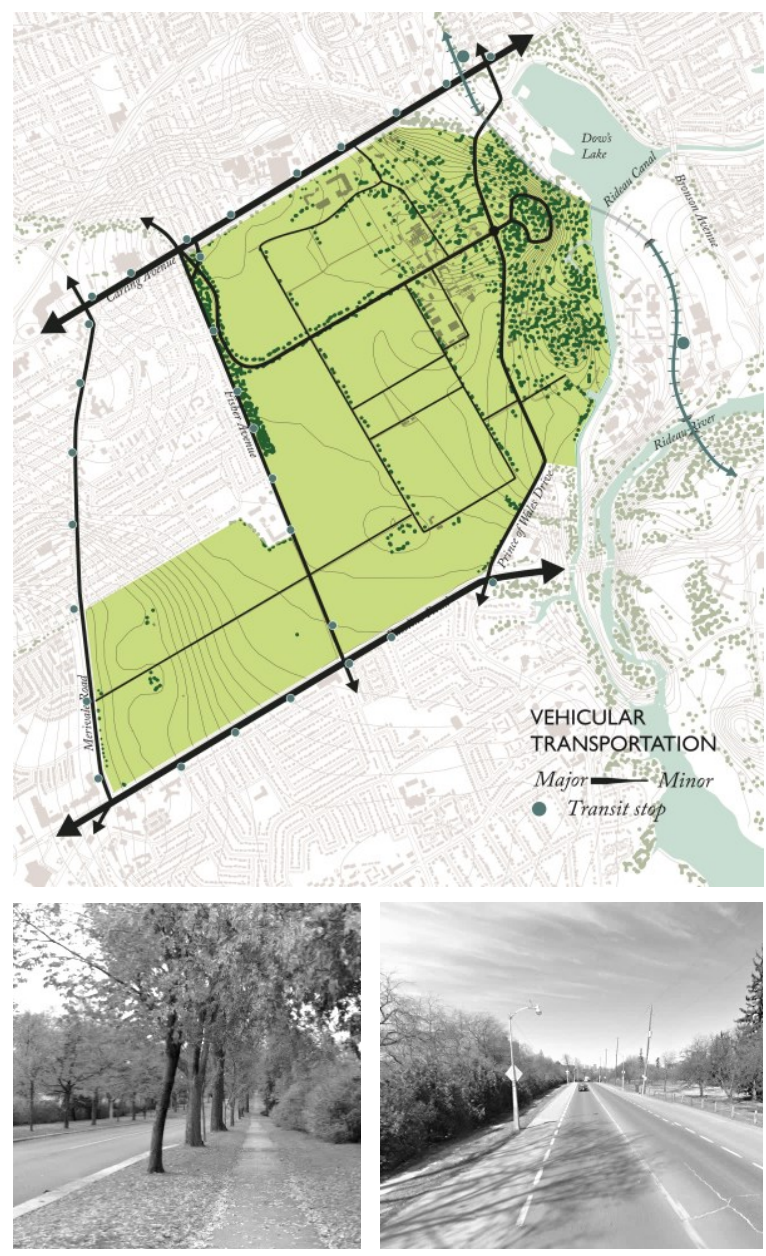

Illustration 18 Vehicular transportation and transit Image 19 NCC Scenic Driverway Image 20 Prince of Wales Drive 
account for a greater density of traffic. ${ }^{26}$

The north-south light-rail route stops at Carling Avenue at the north-east corner of the site and at Carleton University across the Rideau Canal. A second light-rail running along the centre of Carling Avenue has been proposed, but has never gone beyond discussion. ${ }^{27}$

Multiple bus routes run along adjacent roads Carling, Baseline, Merivale and Fisher, although no buses travel along Prince of Wales Drive to serve the existing agriculture museum and interior Farm. The closest bus stop to the Farm is on Carling or Baseline with a 15-20 minute walk along inadequate paving following Prince of Wales Drive.

\footnotetext{
26 "Central Experimental Farm National Historic Site Management Plan (7 of 20)." Central Experimental Farm Integrated Services;Agriculture and Agri-Food Canada;Government of Canada. August 5, 2015. Accessed January 6, 2016. http://www.agr.gc.ca/eng/about-us/offices-and-locations/central-experimental-farm/about-the-centralexperimental-farm/central-experimental-farm-national-historic-site-management-plan-1-of-20/central-experimentalfarm-national-historic-site-management-plan.

${ }^{27}$ Reevely, Paul. "Http://www.ottawacitizen.com/light Rail Carling Avenue/8329830/story.html." Ottawa Citizen, May 1, 2013, Ottawa sec. Accessed January 6, 2016.
} 


\section{CHAPTER 3: CASE STUDIES}

\section{The Princess of Wales Conservatory}

Kew Gardens, London, England

Architect: Gordon Wilson, 1985

Area: 4 500sqm

Built in 1985, the Princess of Wales Conservatory

stands in contrast to the ornate Victorian

temperate houses at Kew Gardens. While the

Victorian greenhouses stand proud of the ground,

the conservatory's low profile merges into the

surrounding area. Built into the ground to

conserve energy, only the triangular roofs are above

ground, nestled into one another to create a series

of glass slopes. Inside are ten climate-controlled

zones to showcase plants from various climate

zones.

While greenhouses provide the opportunity for

year-round activity, any greenhouses on the

Experimental Farm must consider their energy

use. Building greenhouses into the ground helps
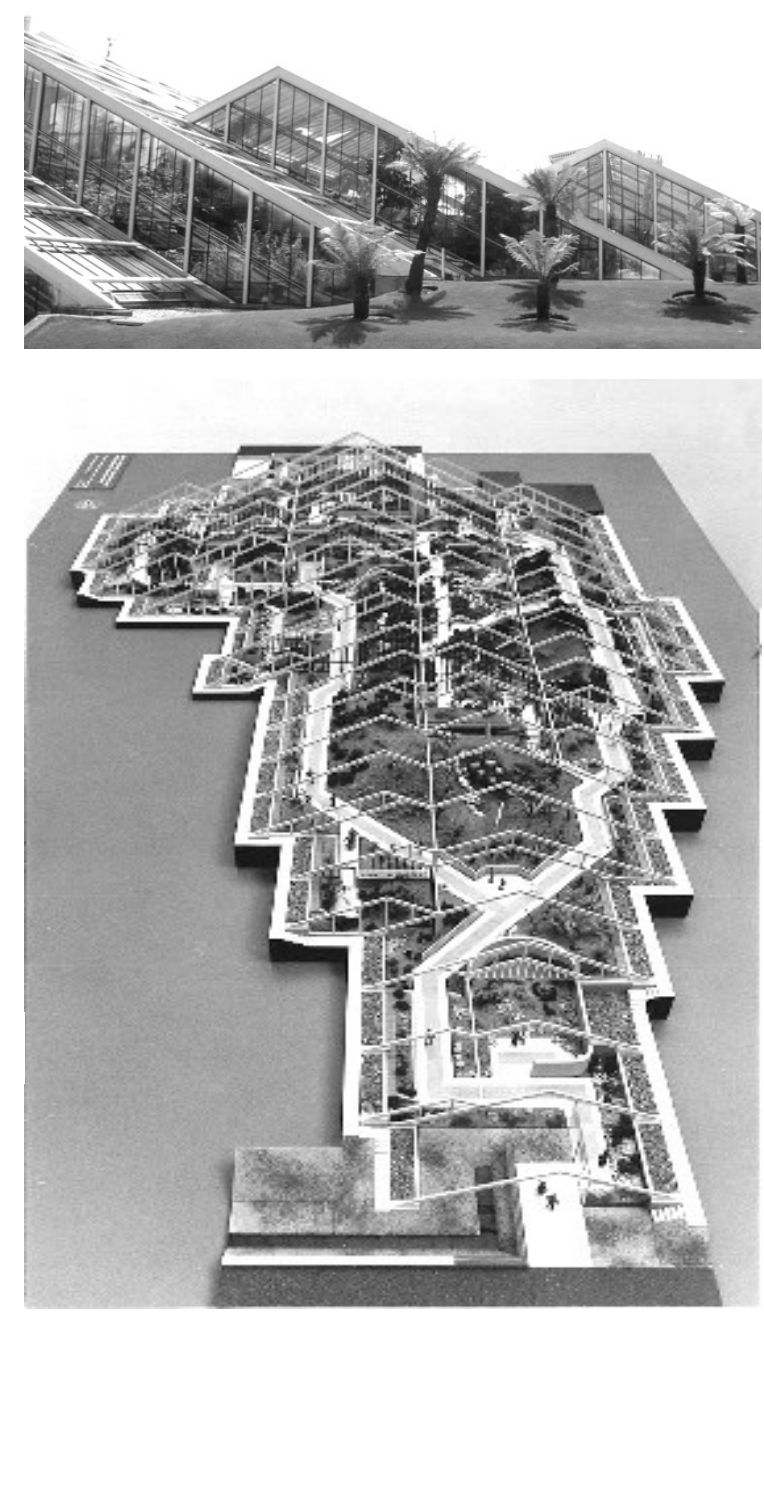

http://www.bdonline.co.uk/another-glass-act-at-kewgardens/5053462.article. 
to maintain a more consistent temperature year-round due to insulating properties of the earth, while reducing energy consumption.

Climate-controlled greenhouses offer the opportunity to grow exotic plants that would otherwise not grow in the local area, but also allows researchers to simulate climate scenarios for the immediate area. If climate predictions indicate changes in rainfall, air quality or temperature in the local area, scientists would be able to test for any effects on crops and inform the public ahead of the change.

\section{Vanke Centre / Horizontal Skyscraper}

\section{Shenzen, China}

Steven Holl Architects, 2009

120444 sqm

Raising the programme above grade allows and a public park to flow continuously underneath the building. The public land is maximised by raising the building, valuable in a city as dense as

Shenzen. The public programme, restaurants and parking garages, is located below the landscape while the private programme, a hotel and
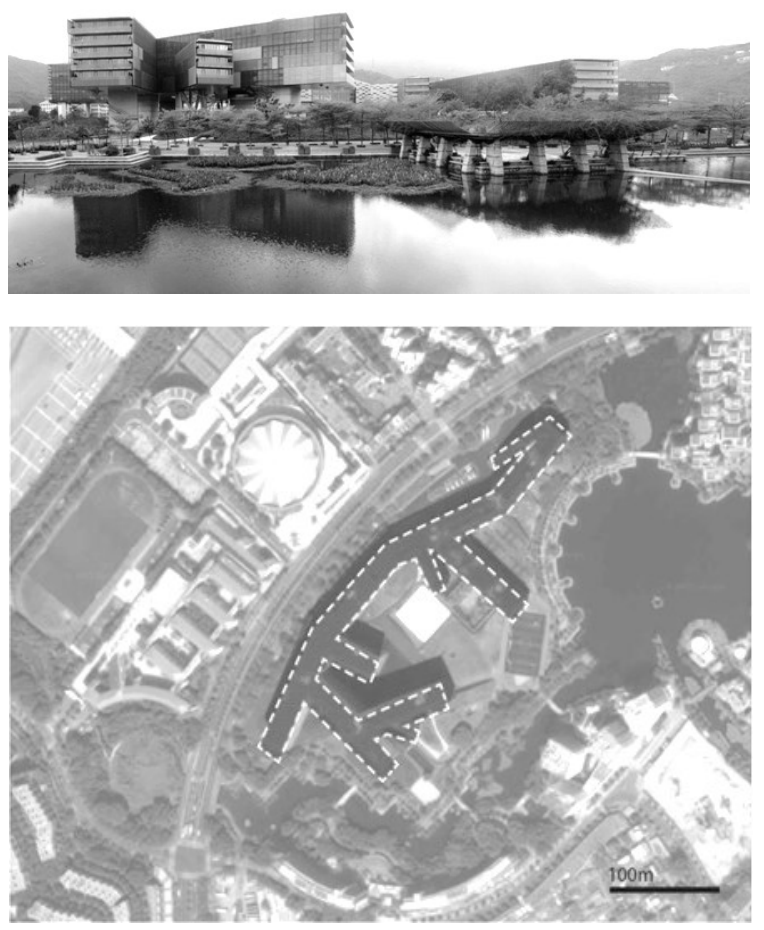
conference/ hotel complex, is placed above. 
Although the Experimental Farm is a federal research facility, it is typically viewed as public, park-like land. Any additional buildings on the site would risk impacting the continuous flow of the generally flat landscape. While raising the buildings would maintain the flow of the site, doing so would be conspicuous and in sharp contrast to the site's heritage value.

Rather than flow under, the landscape can achieve continuity by flowing over the buildings. Raising the landscape rather than the buildings would provide visual continuity, allow the research to occur at the same level as the public and help reduce energy demands for the buildings. Terracing the land as it slopes over the buildings would allow the landscape to remain flat for agricultural purposes and provide an area for researching rooftop crop production.

\section{Darwin Centre}

Natural History Museum, London, England

CF Møller Architects, 2010

16000 sqm

Many visitors to the Natural History Museum are unaware that the museum offers other services beyond the curated exhibitions. To show the public the diversity of activity in the museum, the architects designed a cocoon-like structure that educates the visitor, showcases the laboratories and hints at the millions of specimens in the museum's collections. Visitors travel down ramps inside the cocoon, passing panels describing 
what is being researched, why the experiments

are being carried out, and the methods involved.

Windows look into working laboratories where

cientists are able to work uninterrupted by the

public, with the option of engaging with the

public in an area designated for interaction

between the scientists and the visitors.

Natural Resources Canada owns an extensive plant

and insect collection used for research and

identification purposes, however, the collection

itself also has an aesthetic value. Since the research

buildings are inaccessible to the public, there is an

air of mystery that surrounds the scientists, their

work and the content of the collections. To see
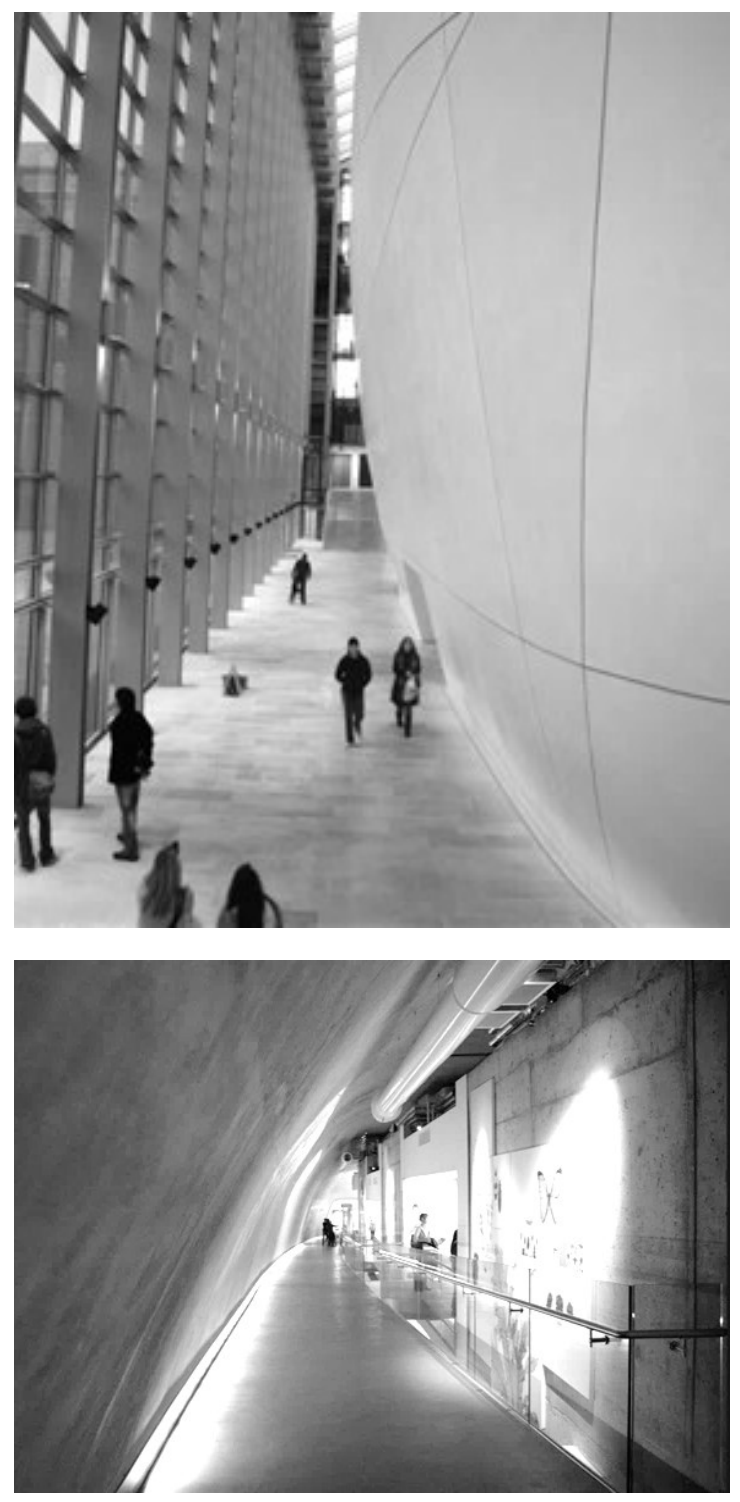

that the scientists are just 'regular people' dispels

the myths of their work and makes the discipline

more accessible to the general public.

Image 25 Darwin Centre interior

Stuart Pilbrow / CC-BY-SA 2.0

Image 26 Darwin Centre exterior

Nicolas De Camaret /CC-BY-2.0 


\section{Beijing Olympic Forest Park}

\section{Beijing, China}

Sasaki Associates Inc., 2008

68000 sqm / 16.8 acres

Constructed for the 2008 Beijing Olympics, the

park was designed to become a major feature of the city after the games. Located on the outskirts of the city, the park marks a transition away from dense, crowded urban settings to a city that promotes sustainable urban design by embracing local ecologies. The environmental effects of the park on the city have been studied, including dust detention, heat-island effect and air pollution levels. Walkways change elevation throughout the park, offering the visitor unusual perspectives by viewing elements from above and below.

Rather than separate the visitor from sensitive research fields with utilitarian fences, elevated or sunken walkways on the
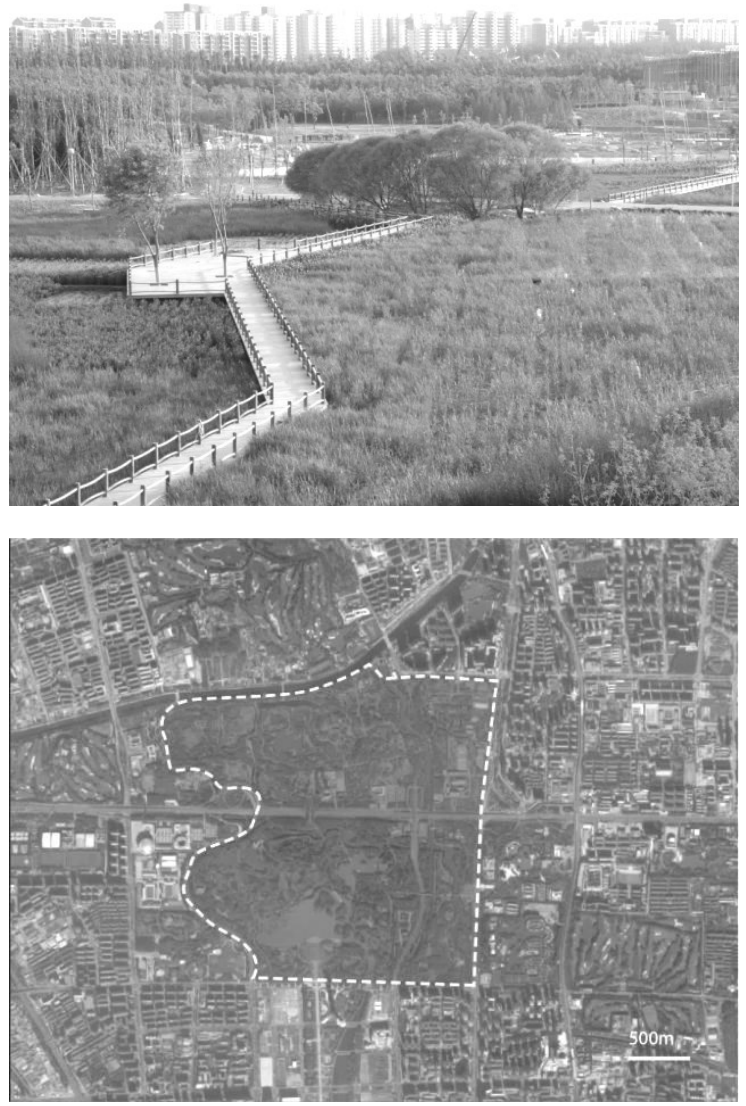

Image 27 Olympicpatkpathways

Yesol Park /CC-BY-2.0

Image 28 Olympicpark outline 
Experimental Farm can protect the fields while providing a more visually connected and varying experience for the visitor. Elevating certain walkways can also separate various speeds of traffic through the Farm, creating designated pedestrian and vehicular routes.

\section{Cells of Life}

Jupiter Artland, West Lothian, Scotland Architect: Charles Jencks, 2010

20 000sqm

Cell of Life is composed of a series of ramped stepped hills and curved ponds. The landscape is created in a picturesque style with carefully placed hills and lakes to control views and paths. The forms are derived from mitosis, the division of cells. 'Cells of Life' is a microscopic, cellular process interpreted as an immersive landscape - a sculptor's interpretation of a natural process that is typically only seen through a scientific

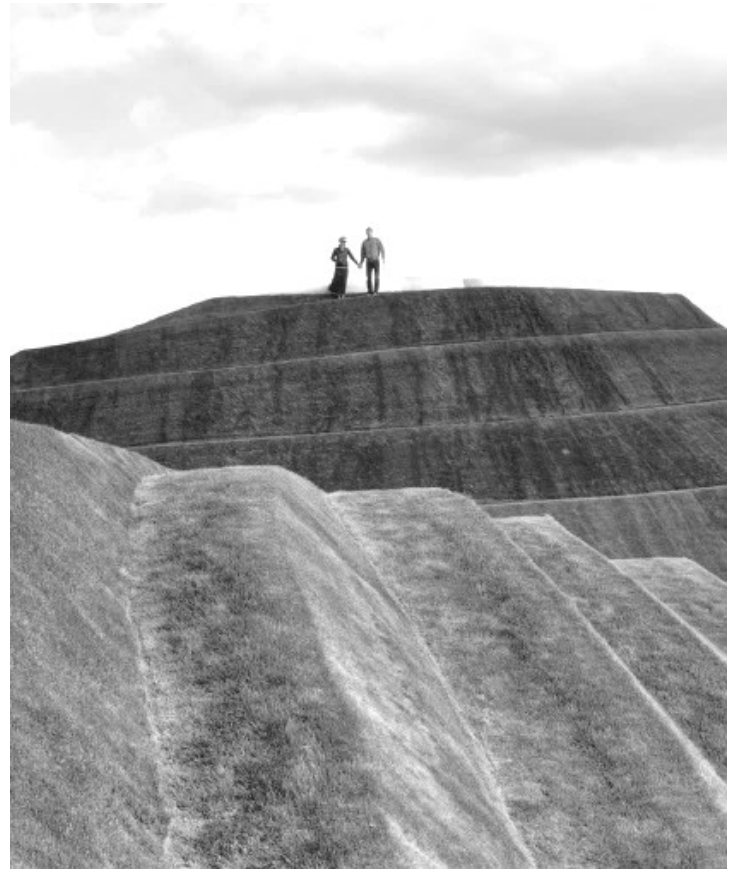
viewpoint.

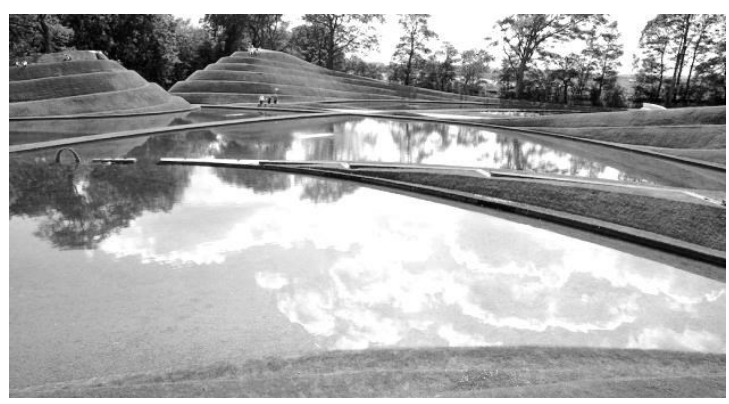


On the Experimental Farm, the landforms should help to describe scientific processes that are being researched. Along with crop production, the Experimental Farm studies the health of watersheds. The health of watersheds can be described on the site with the treatment of runoff water from adjoining neighbourhoods. Filtered storm water can be used for water features and irrigating the greenhouses. Soil that is displaced from constructing buildings on the Experimental Farm can be used to divert water into reservoirs required for the greenhouses and storm water management. 


\section{CHAPTER 4: DESIGN}

\section{Existing Programme}

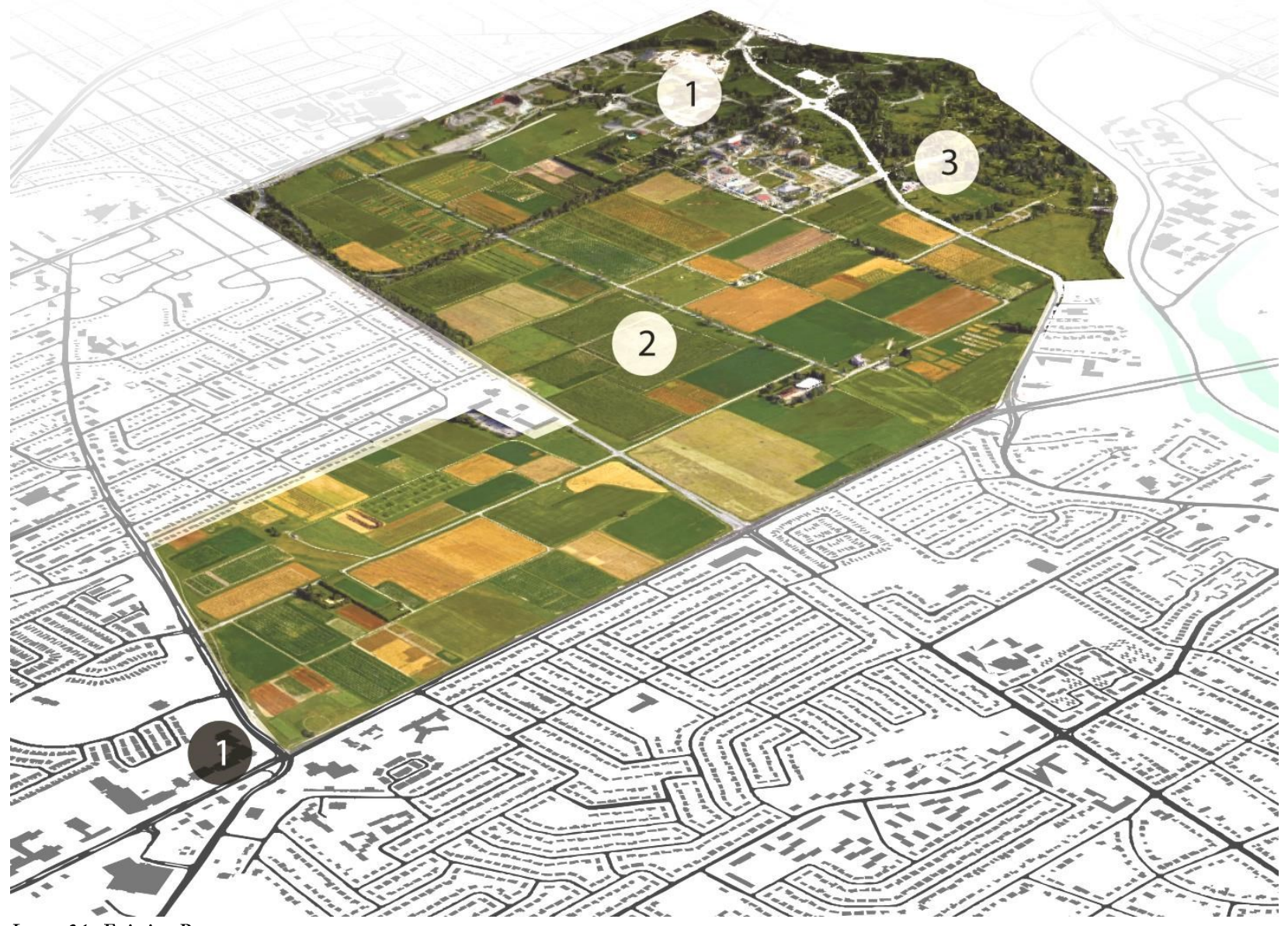

Image 31 Existing Programme

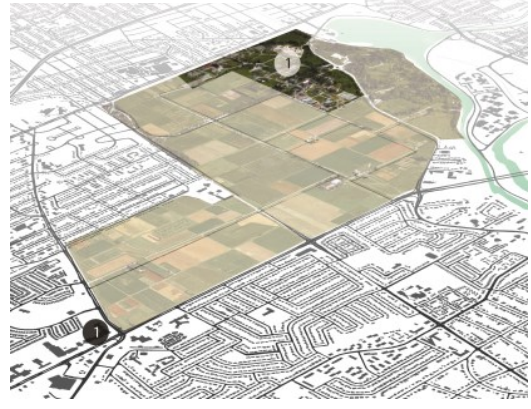

Historic

50 acres

Agriculture Museum 3 acres

Laboratories

$105,000 \mathrm{~m}^{2}$

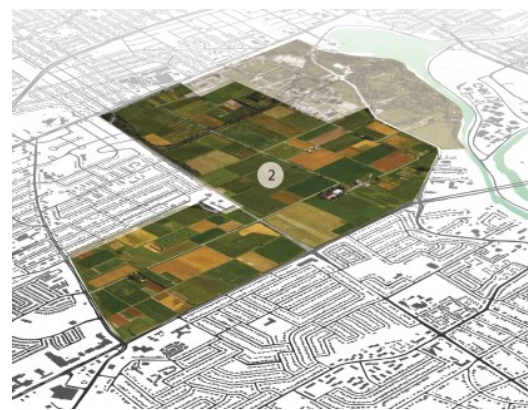

Research Land

295 acres

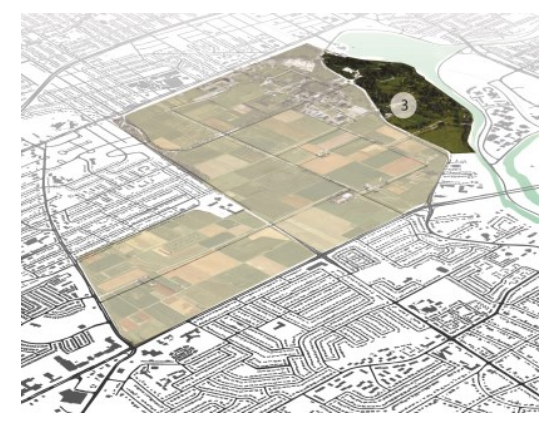

$\begin{array}{ll}\text { Dominion Arboretum } & 36 \text { acres } \\ \text { Wildlife Garden } & 18 \text { acres }\end{array}$ 


\section{Proposed Programme}

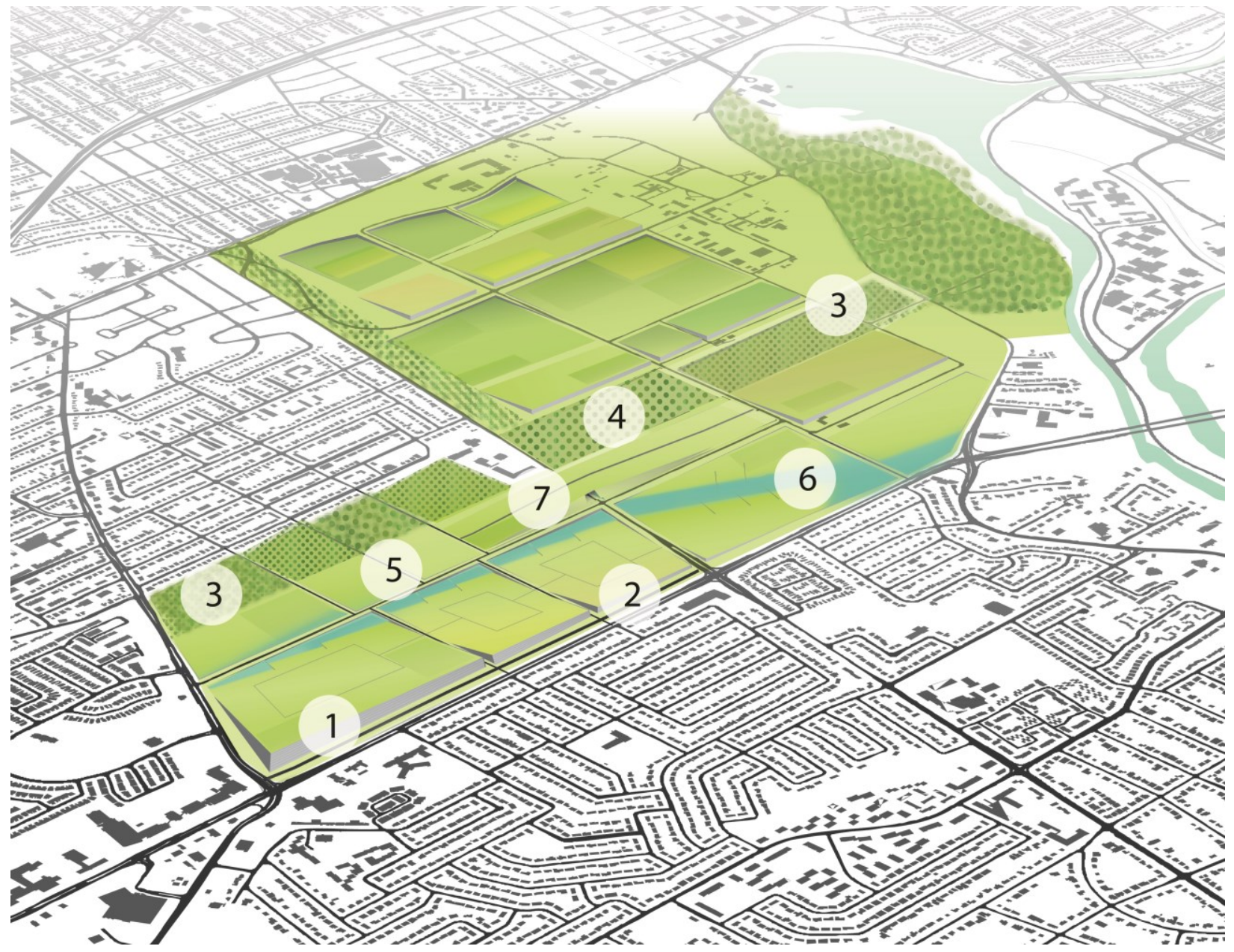

Illustration 32 Proposed programme

The existing research fields, government research buildings and arboretum remain, enhanced with proposed programming that encourages interactions between the city's residents and the natural systems at on the site. The arboretum and wildlife garden are expanded across the site to encourage interactions between the public areas and the working fields. The existing government buildings will join the existing Agriculture Museum in an expanded open-air museum of Canadian agriculture. 


\section{Expanded Research Facilities}

$\begin{array}{ll}\text { Urban Crop Production } & 50,000 \mathrm{~m}^{2} \\ \text { Climate Research } & 50,000 \mathrm{~m}^{2} \\ \text { Laboratories } & 100,000 \mathrm{~m}^{2}\end{array}$

- Additional research buildings are prominent on the site

- Expanded facilities for growing foods in urban environments and in changing climates

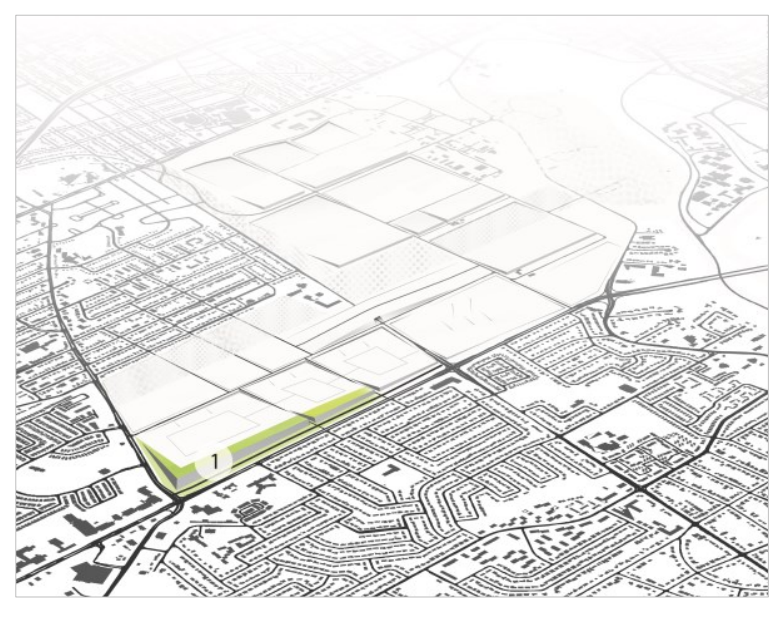

Illustration 33 Research facilities location

\section{Visitor's Centre \\ $5,000 \mathrm{~m}^{2}$}

\section{Exbibition and educational areas}

- Adjacent to research labs to connect visitors with scientists

- Showcase collections used by the research centre

- Engage with community by showcasing methods and discoveries

- Explain how elements of the Farm work and interact with the city

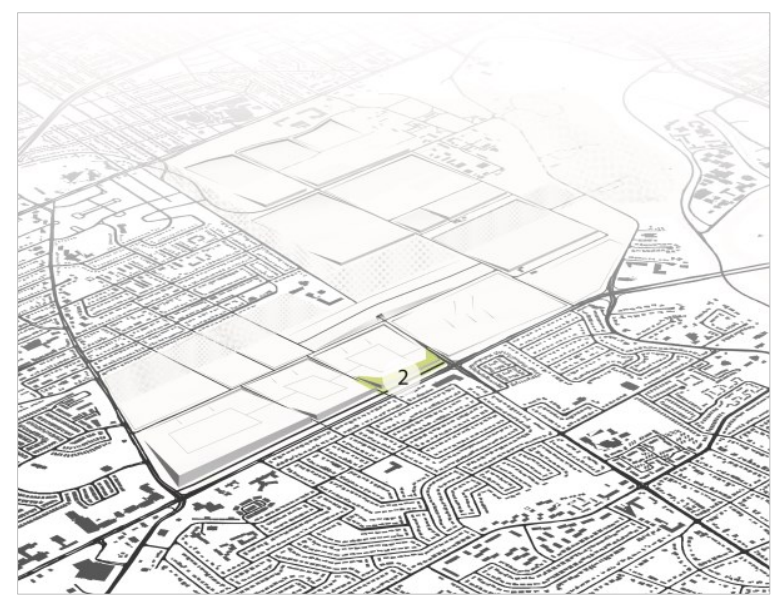

Illustration 34 Visitor's Centre location

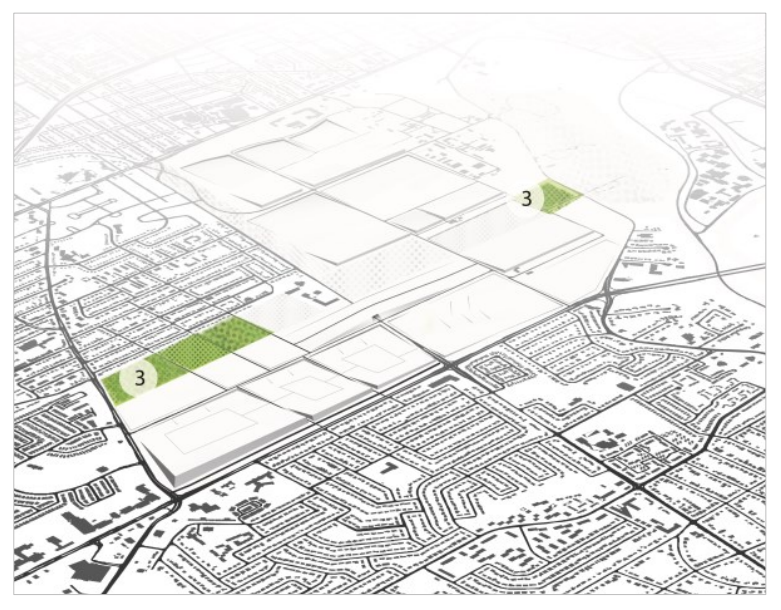

Illustration 35 Urban forest locations 
4 Orchard

50 acres

Research and recreation

- Testing cultivars for urban environment

- More open than urban forest to maintain views across site

- Wind break for outdoor activities and building protection

\section{Community Gardens}

3 acres

\section{Recreation}

100 plots at $250 \mathrm{~m}^{2}$

- Encourage local residents to engage with the site

- Demonstrate that the research is not just for commercial farmers but for the general public

\section{Water Management}

1,545,000m³/year + design storm (Appendix A)

Catchment area $\quad 670$ acres

Storage capacity $\quad 1,800 \mathrm{~m}^{3} /$ day

$\left(90 \mathrm{~m}^{3} /\right.$ day per $5,000 \mathrm{~m}^{2}$ of interior irrigation)

- Enhance quality of urban life

- Strengthen connection between urban environment and natural systems

- Use landscaping to guide flow of water over the site

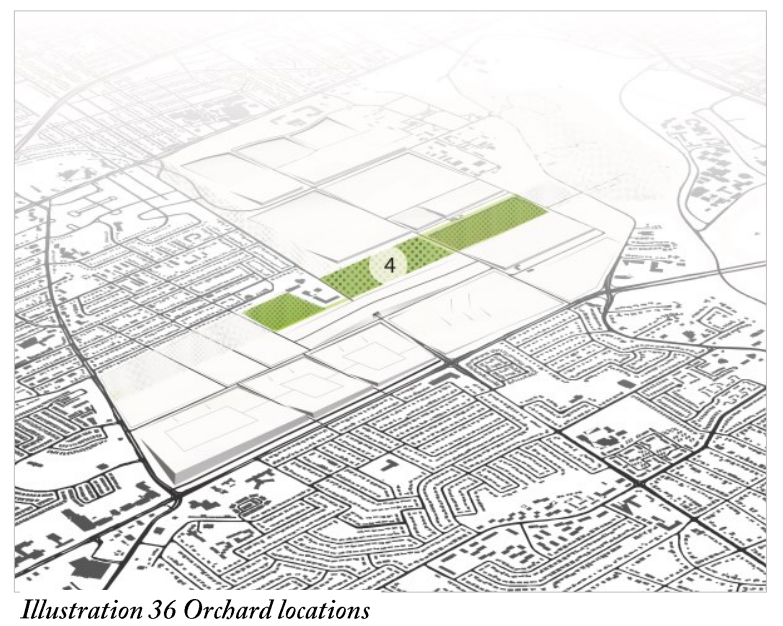

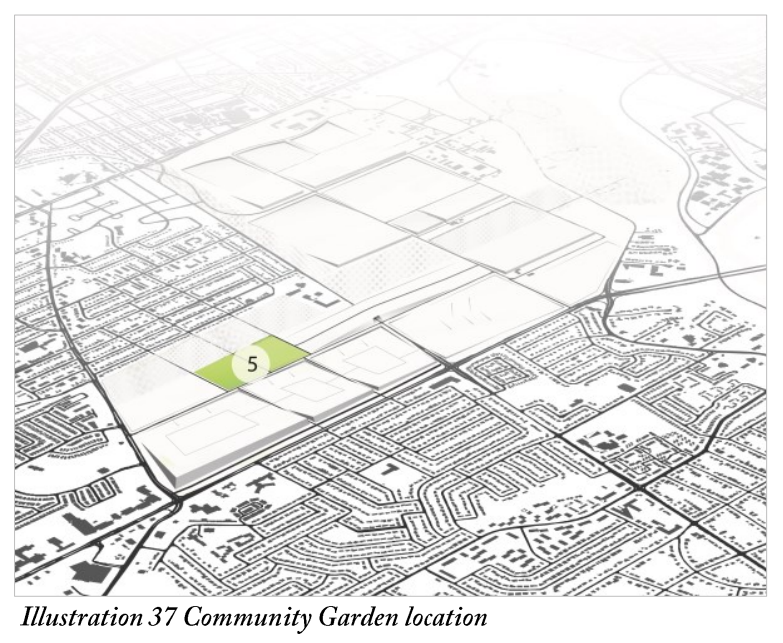

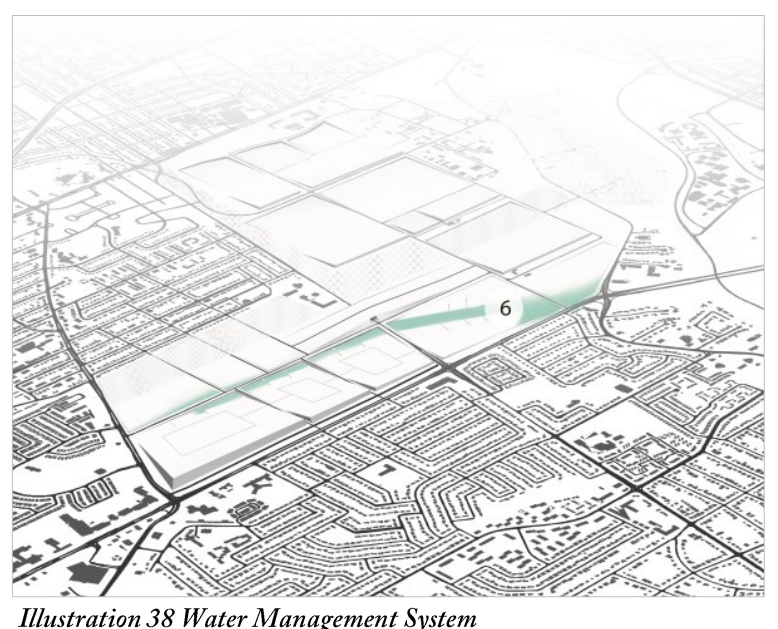

Illustration 38 Water Management System 


\section{Land bridge and pathways}

\section{Pedestrian and bicycle}

- $\quad$ Stronger connection to existing cross-city trails

- $\quad$ Designed for use in summer and winter

- $\quad$ Separate pedestrian and bicycle from vehicles

- $\quad$ Land bridge as lookout point for site

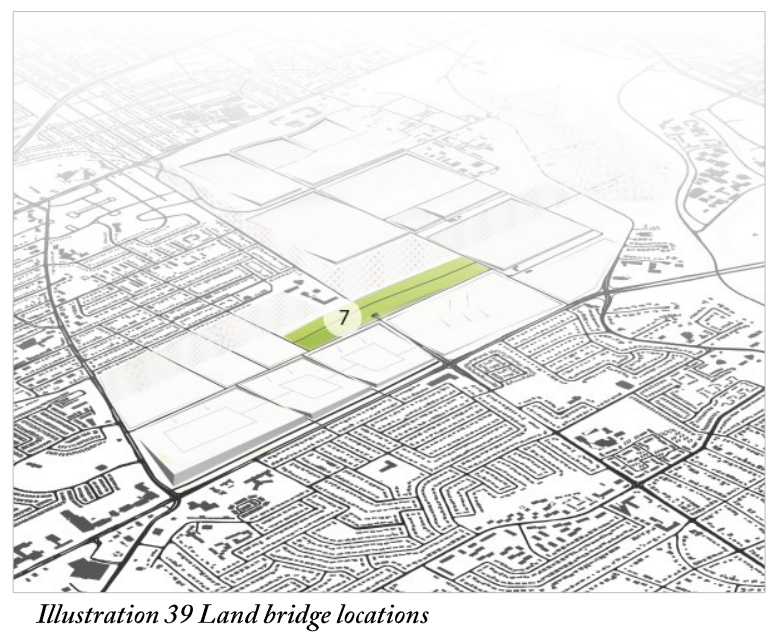




\section{Design Approach}

To rekindle public interest in the Experimental Farm, the site needs an identity that is instantly recognisable. A distinctive landscape typology emphasises the site's edges, protects the interior, and forms areas to connect with the community. The varying topography and the programmes it inspires curiosity in the visitor, inviting them to explore the landscape.
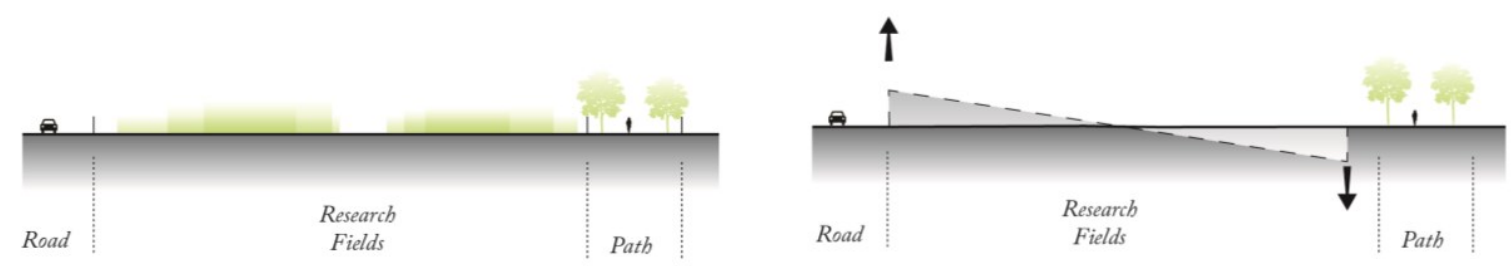

Illustration 40 Original and proposed topographysection

\section{Topography}

To unify the site, a subtle landscape typology was developed that allows the fields to double as wind buffers, sound breaks, water channels and protective roofs while achieving maximum acreage for the research fields. Slight alterations to the topography of the site maintain the character of the Farm, respecting it as a heritage site while generating a diverse landscape for the contemporary visitor.

The site was divided using existing roads on the site and extending pedestrian paths from adjacent neighbourhoods. The resulting grid forms the base of the new topography. The grid defines the path system, at the original grade of the Farm. The topography of the fields is then altered within each section. 


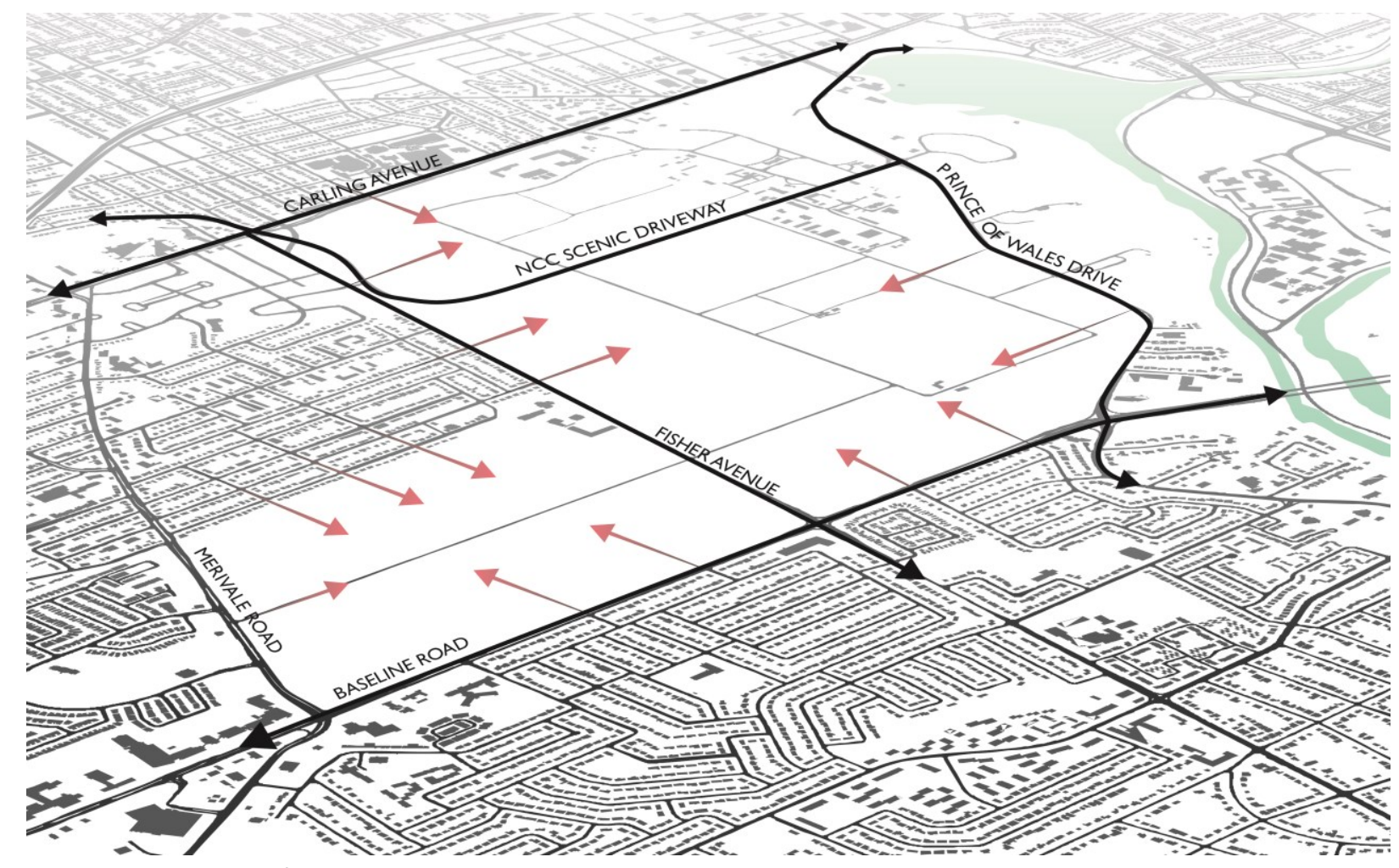

Illustration 41 Extension of city into site

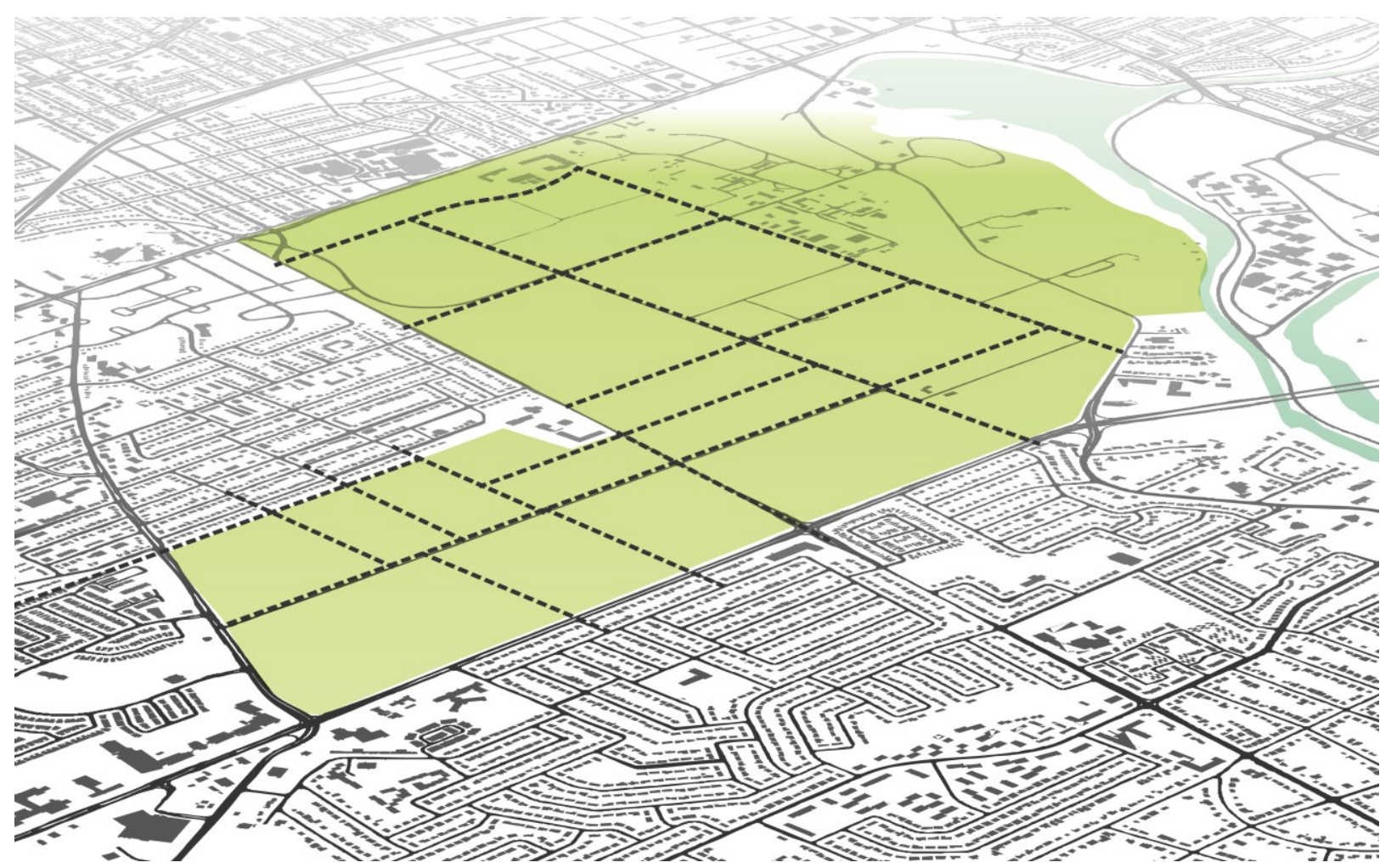

Illustration 42 Division of site 


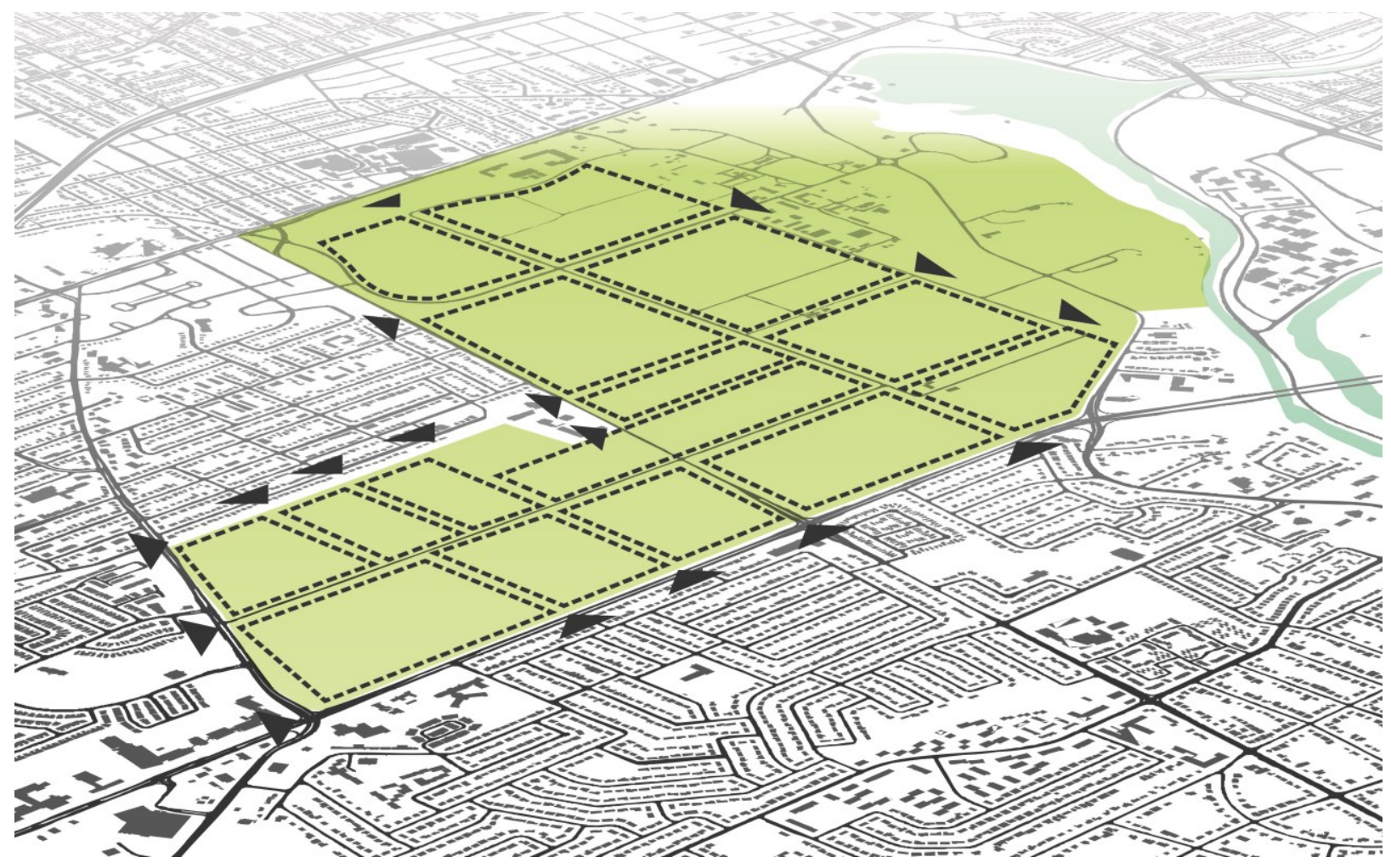

Illustration 43 Pedestrian trails and access points

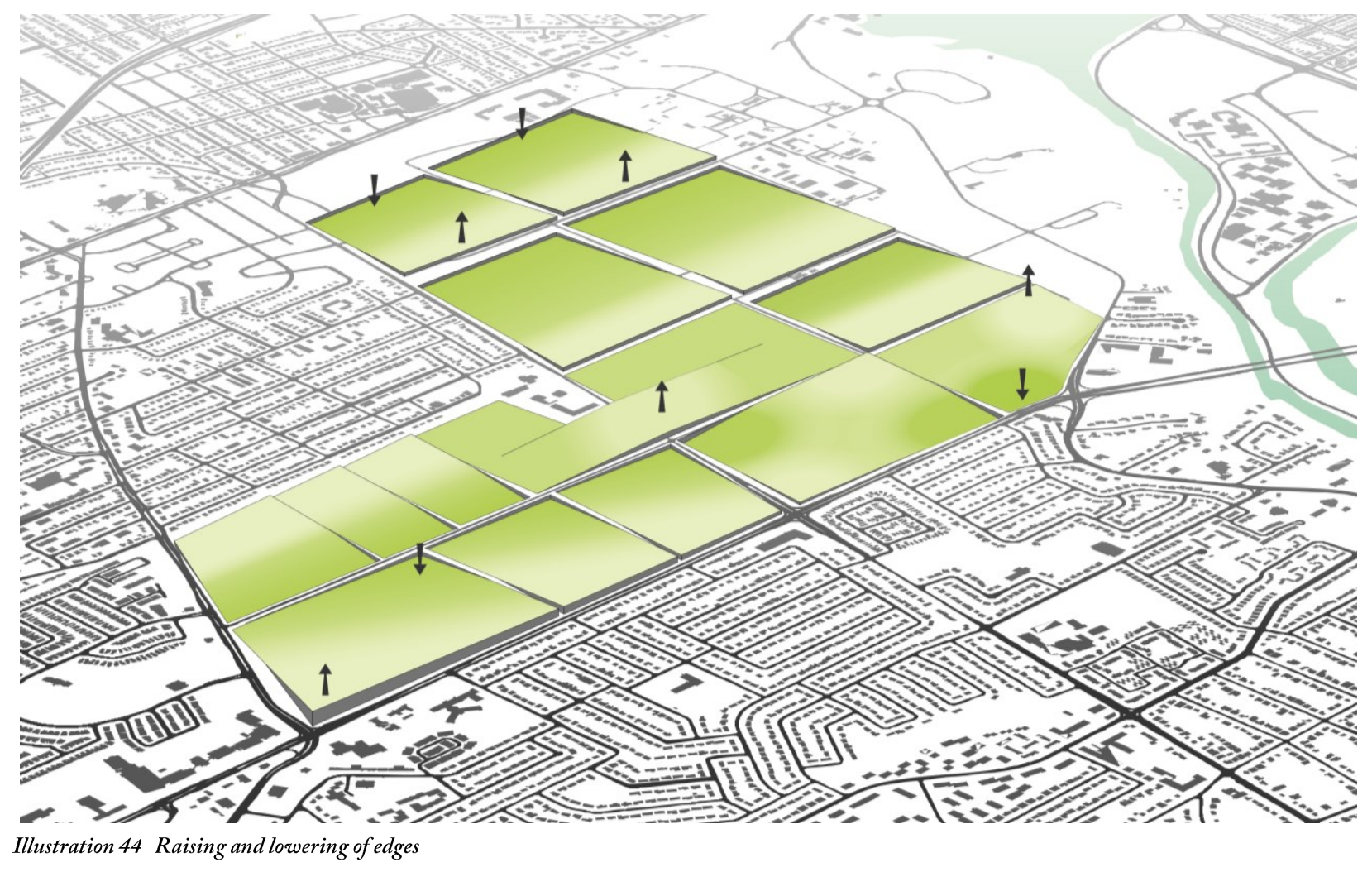




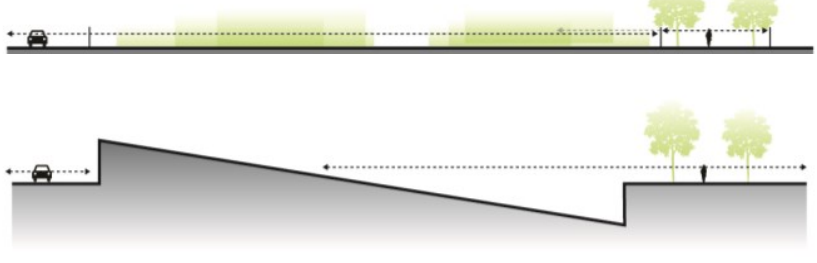

Illustration 45 Existing view and proposed view

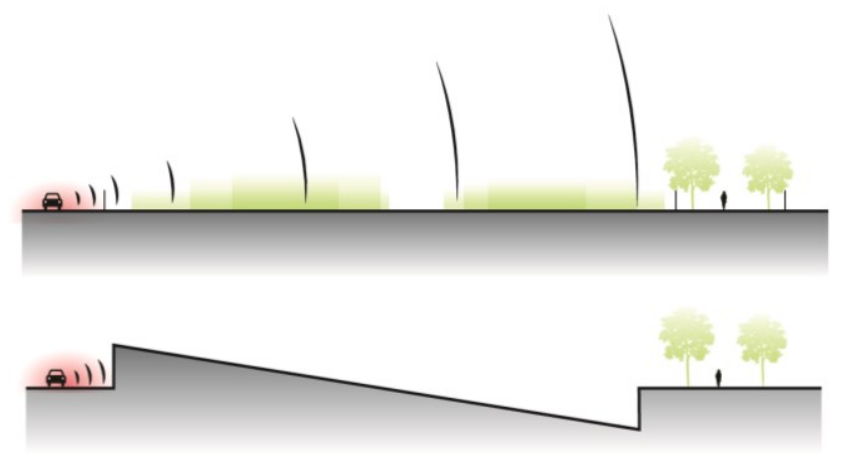

Illustration 46 Existing sound and proposed buffer

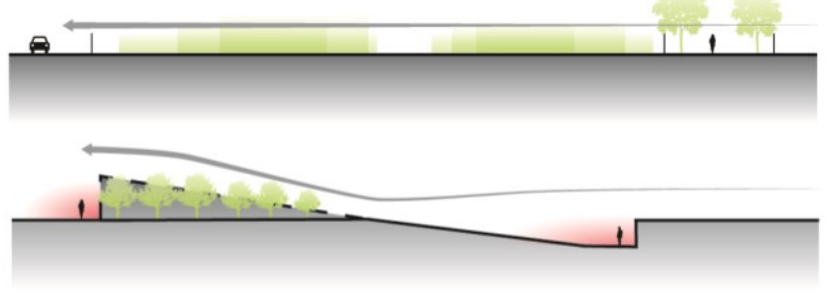

Illustration 47 Existing wind and proposed buffer

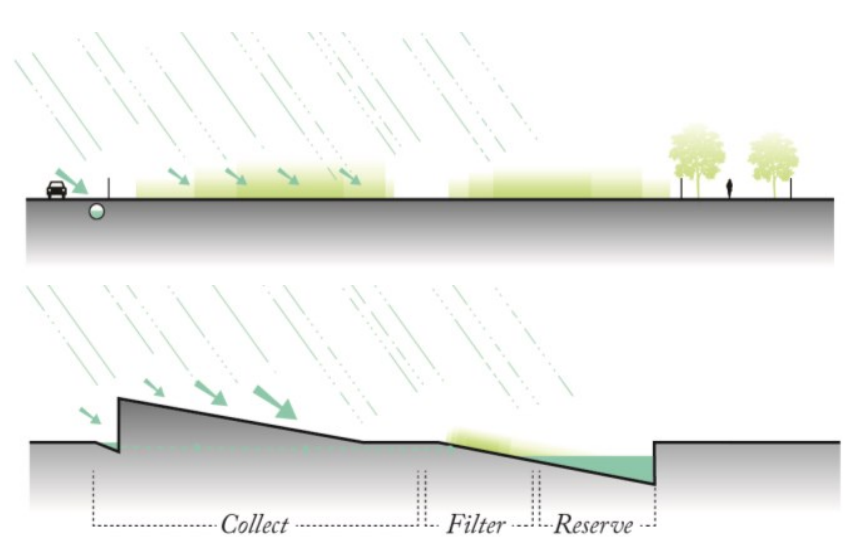

Illustration 48 Existing water and proposed collection method 


\section{Edges}

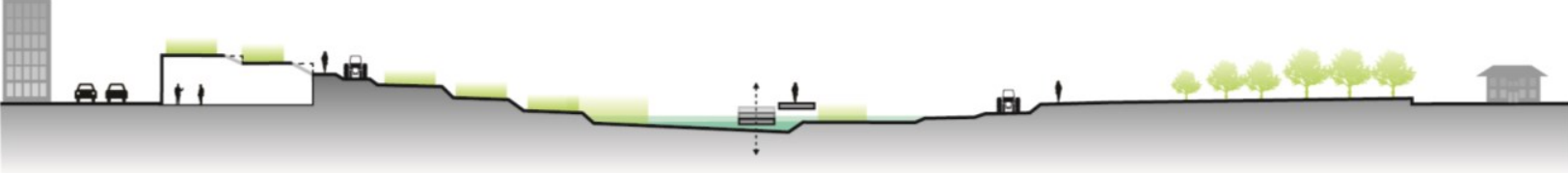

Illustration 49 Built edge and grown edge typology

\section{Baseline Road}

Depending on the programme within the division, the corners of the fields are raised up to form buildings and windbreaks or depressed to channel water and create view corridors. The potential of high-rise developments along Baseline Road is anticipated, and will create a strong built edge within decades. Research buildings and a visitor centre provide continuity of the buildings along Baseline Road.

The built edge slopes down towards the Canal creating a smooth transition from the scenic Canal to the commercial buildings along Merivale Road (Illustration 44). The depression also forms the main water reservoir and provides extended views into the centre of the Farm from the road (Illustration 45,47). Breaks in the edge create clear arrival points and provide glimpses into the Farm's interior, breaking the current monotony of the flat site. The breaks also double as water collection corridors for runoff from Baseline Road. As visitors enter the site through one of the breaks, they can see the water system at work with vegetated swales and reed beds that filter the water, collecting in the interior of the site. 


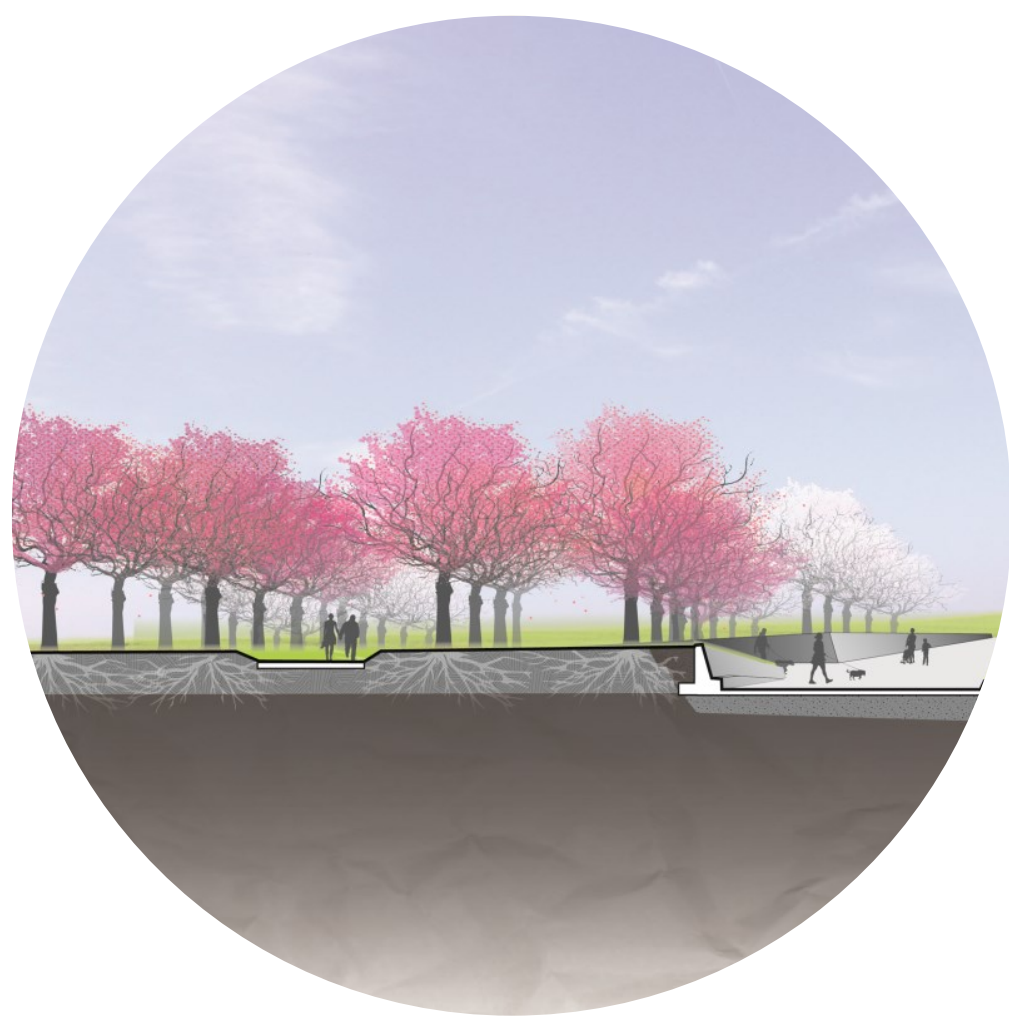

Illustration 50 Orchard/grown edge in spring

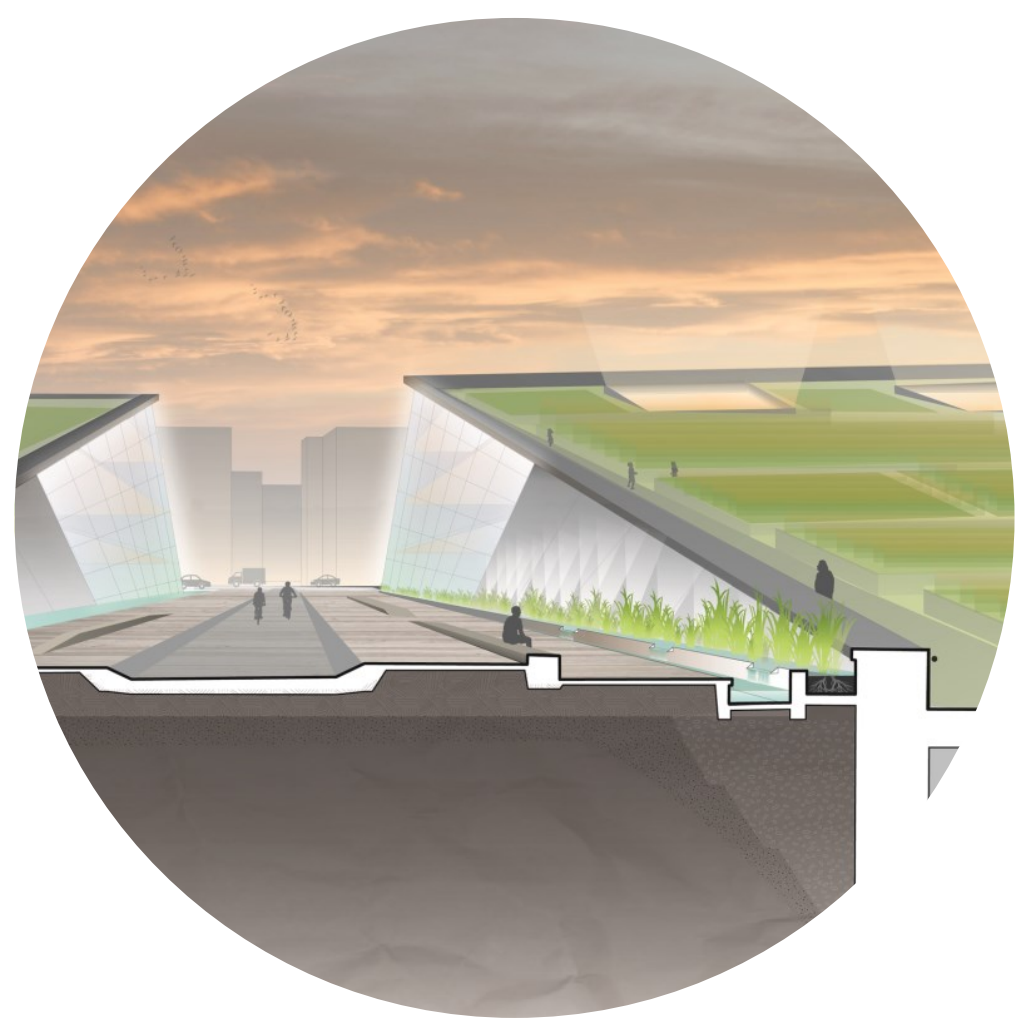

Illustration 51 Research edge/ break in built edge 
The buildings that line the breaks contain public programming. As visitors pass through a break, they may also enter the building to access public galleries and more information on the site.

Research laboratories and greenhouses line the edge, visible from Baseline Road. A sloped green roof provides a seamless transition between the fields and the building, and provides another unique testing area for urban crop production (Illustration 51, 52). A glazed south wall admits ample light for the front of the building, while large sky lights illuminate the building's interior. In the evenings, light from the indoor facility will be visible from the exterior as the sky lights become beacons for the Farm. LEDs or fullspectrum blubs are essential for successful indoor crop production in northern climates, and crops may be grown with artificial light alone..$^{28}$ The colour of light may be customised for each crop depending on the growth stage, for example blue light to encourage vegetative growth and red light for fruiting, which will result in different coloured light emitted from the sky lights.

\footnotetext{
${ }^{28}$ Nederhoff, Elly, Dr. "LEDs in Spotlight." Greenhouse Canada, September 27, 2011.
} 


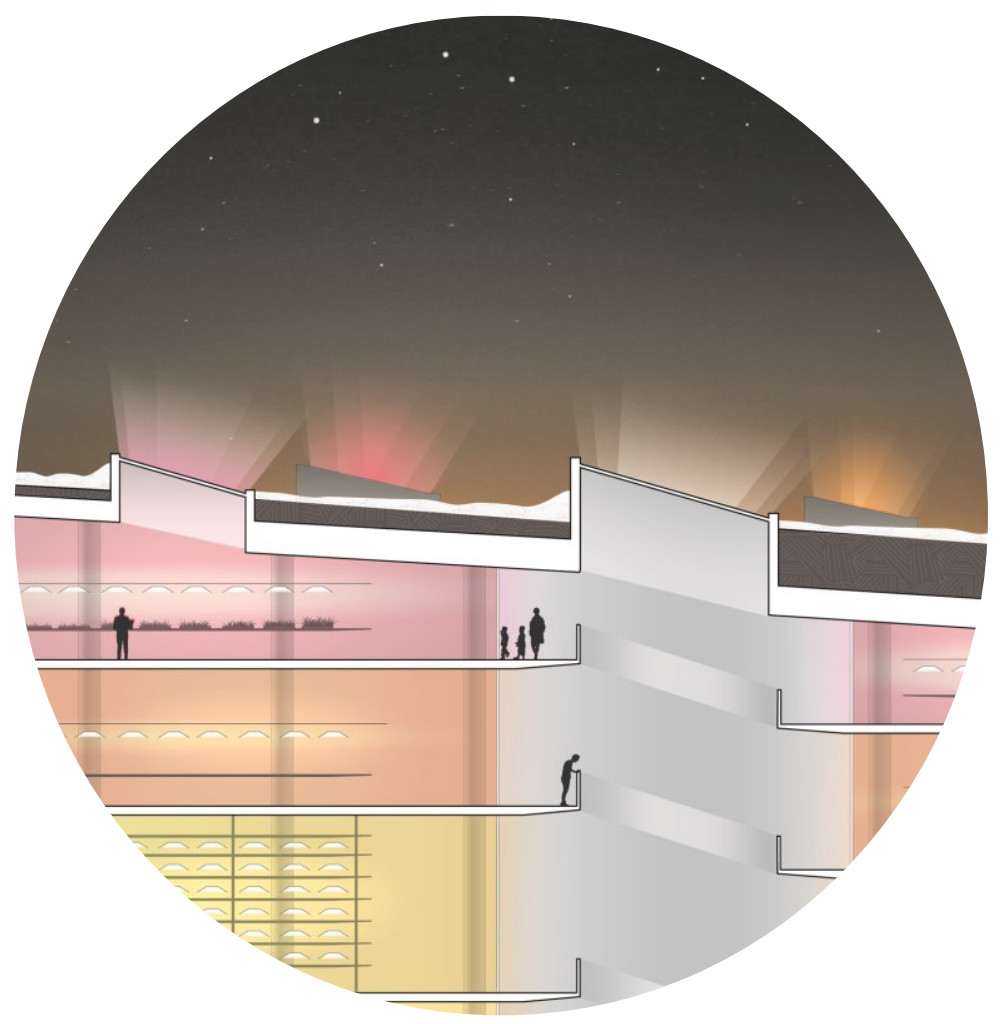

Illustration 52 Section through visitor's centre and research facility

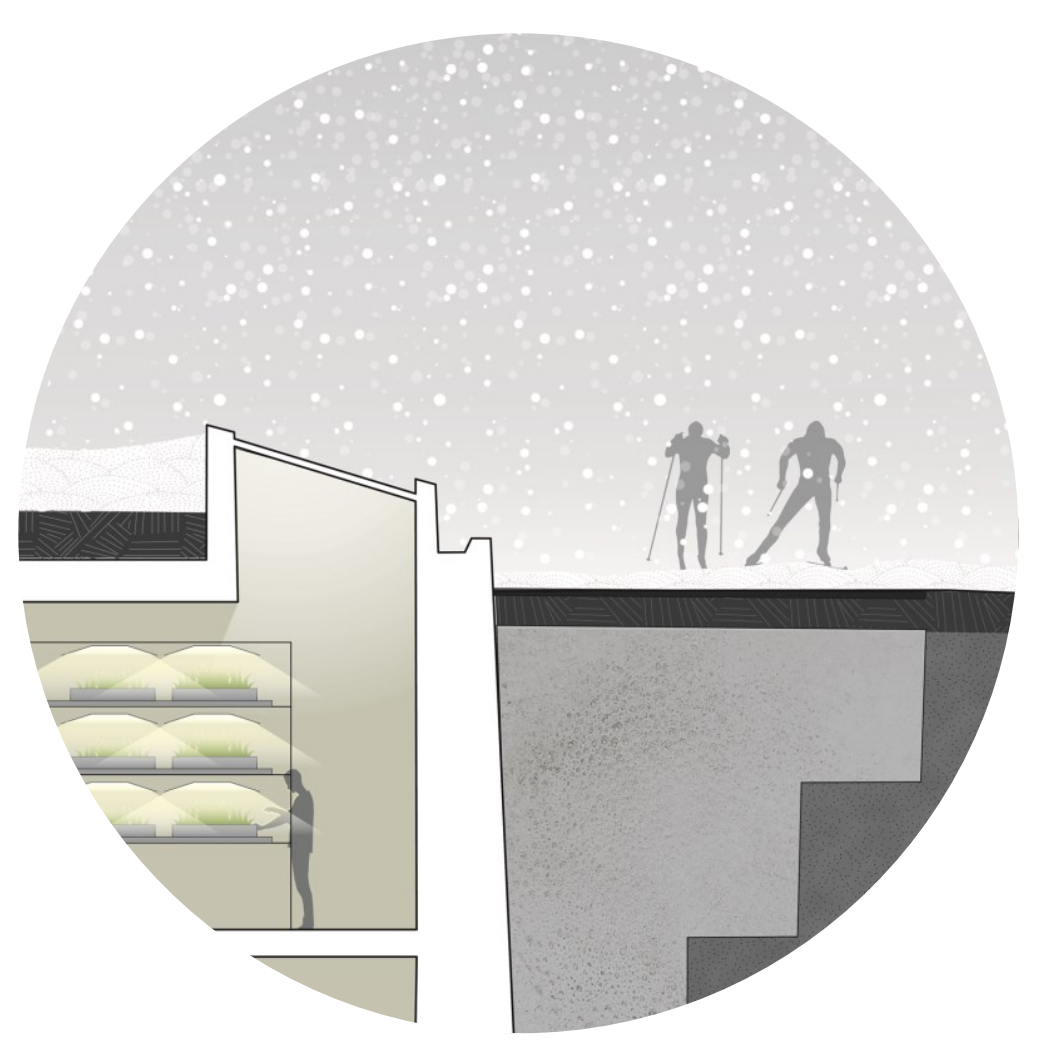

Illustration 53 Research facility and public recreation path 


\section{Merivale Road}

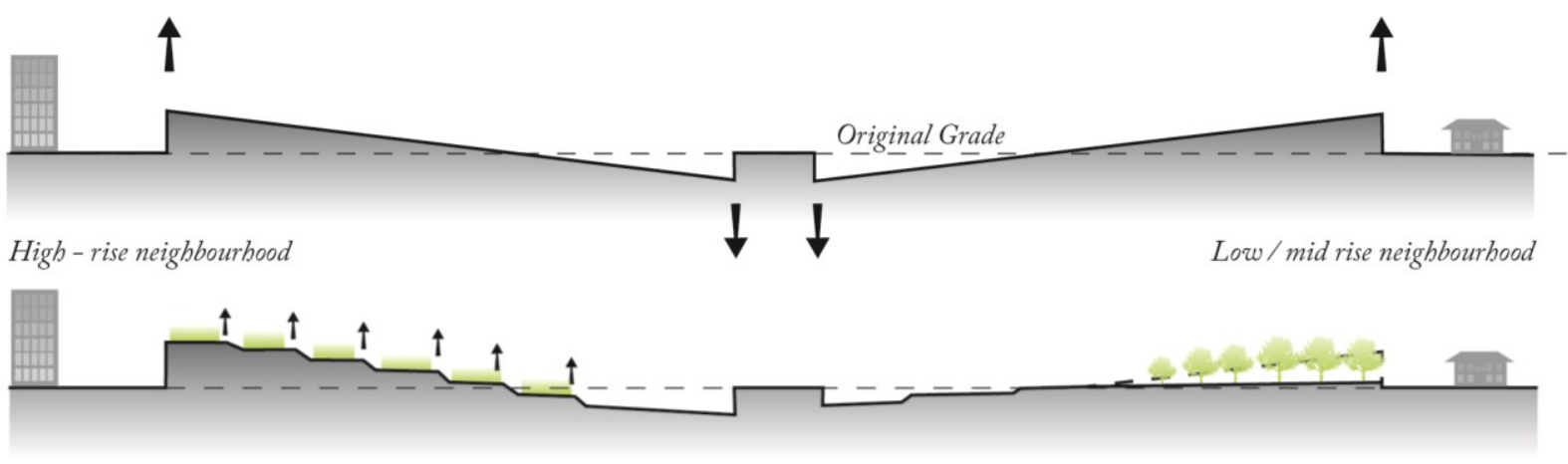

Terrace research fields for agricultural use

Achieve height with urban forests and orchards for residential areas

Illustration 54 Section parallel to Merivale Road showing built and grown edge

The Merivale edge acts a water collection and

filtration edge, channeling the water into the

site with converging slopes. The soft, planted

edge adjacent to the low-rise residential

neighbourhood is a contrast to the strong built

edge along Baseline, and protects the site from

winter winds. The built edge along Baseline is

contrasted with the softer grown edge along

the residential neighbourhood. The urban

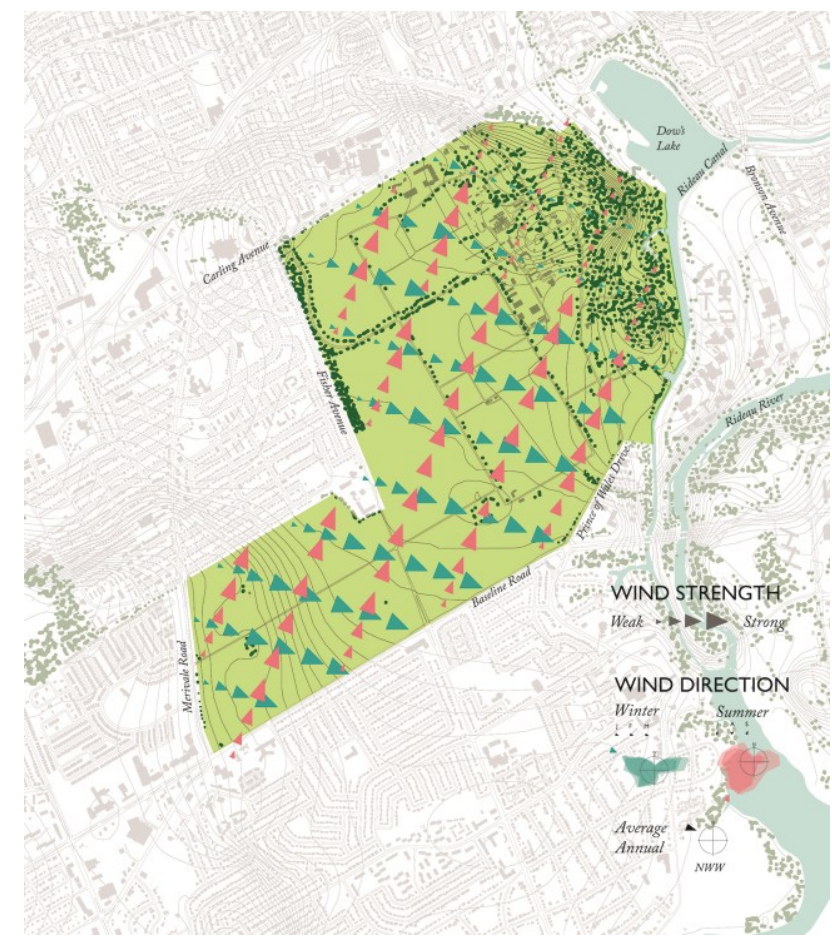

forest maintains the height along the edge

while creating a more permeable edge suitable

for the character of the neighbourhood. 


\section{Paths and urban forest}
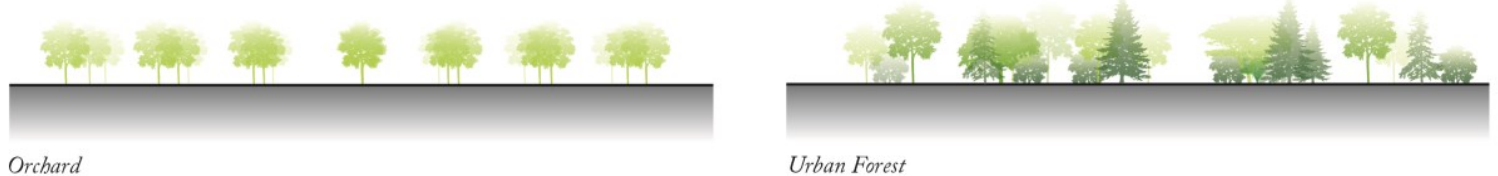

Urban Forest
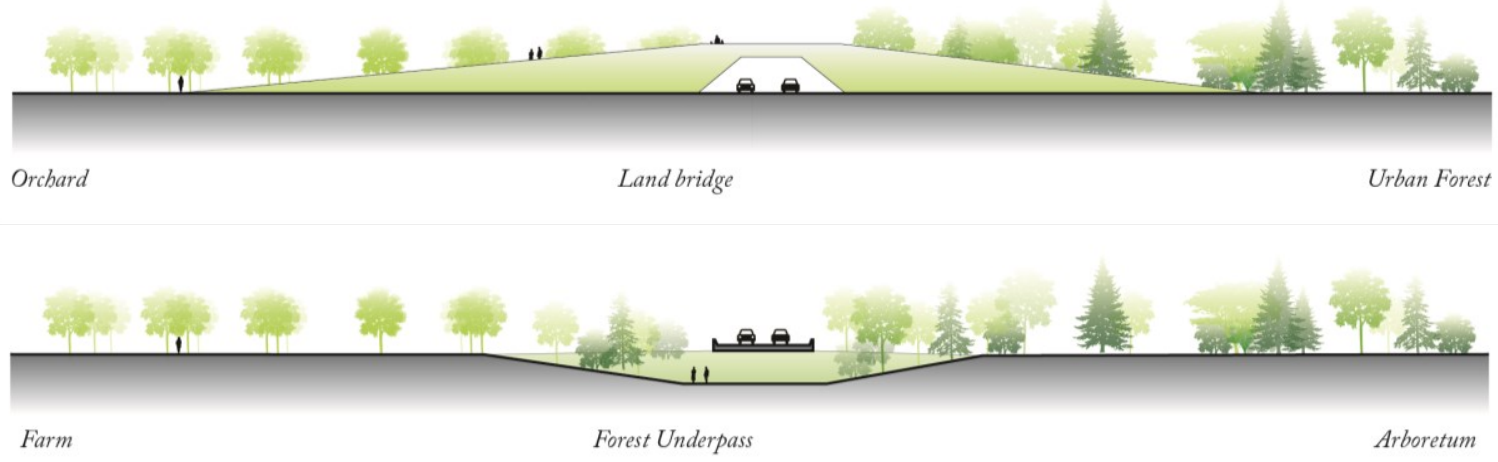

Illustration 56 Sections through grown edge and land bridges

While the topography varies across the site, the main pathways remain at the original grade of the Farm. As the original grade is relatively flat, the terrain is easily accessible by all visitors. Altering the topography of the fields and leaving the paths at grade physically separates the visitor from potentially sensitive research while maintaining a strong visual connection to the site. The site's paths become more dynamic to travel along as the landscape frames and conceals views.

The grown edge extends across the site, connecting to the arboretum to create a treelined corridor. Part of the corridor includes a research orchard planted in a structured grid, contrasting with the relaxed planting of the urban forest. Planting on a grid enhances views across the site rather than obscuring them by creating strong converging lines. 


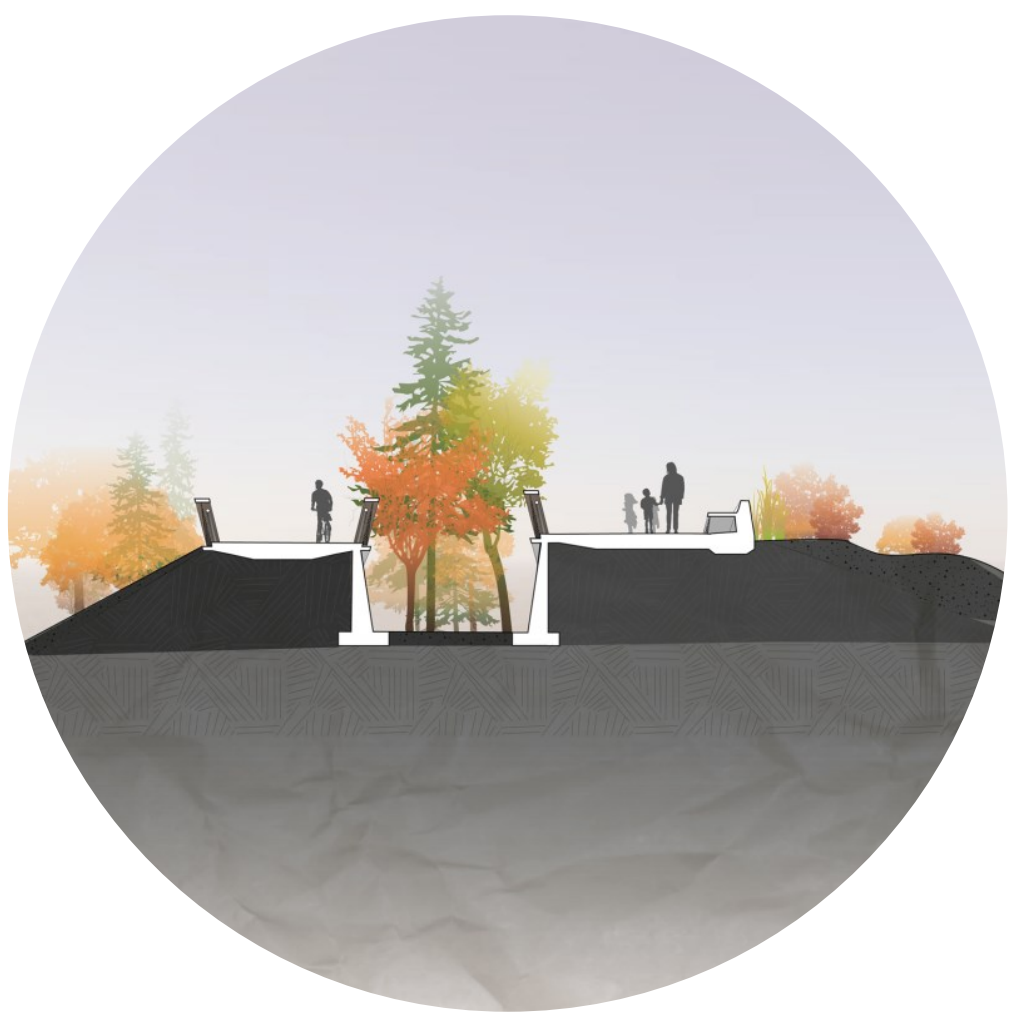

Illustration 57 Section through grown edge and land bridges

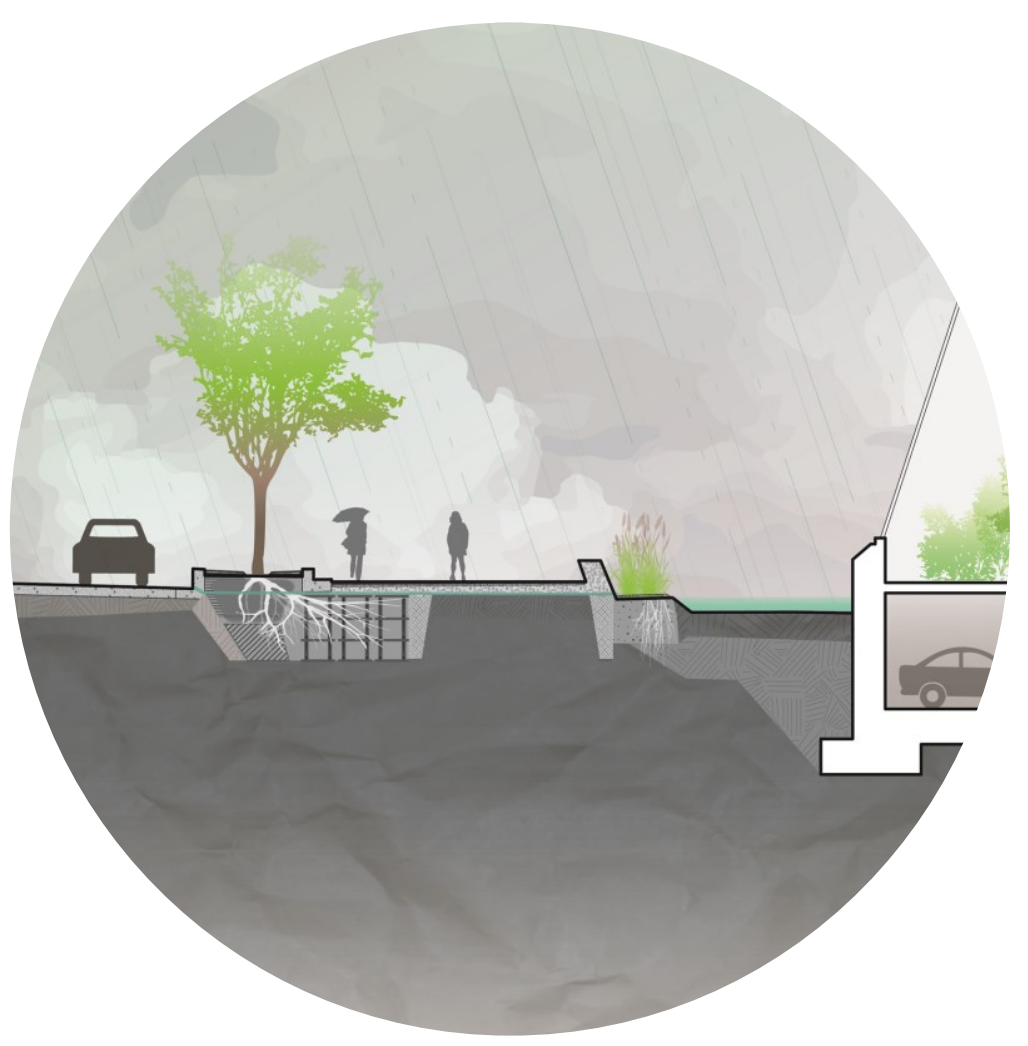

Illustration 58 Section through Baseline Road pavement 
The land bridge over Fisher Avenue ensures a seamless flow over the site for vehicles and pedestrians. As the highest internal point on the Farm, the land bridge is also a lookout offering views over the adjacent trees and research fields.

To improve the connection between the arboretum and the Farm, an unobtrusive underpass below Prince of Wales Drive provides continuity and minimal impact to the existing features.

\section{Water}

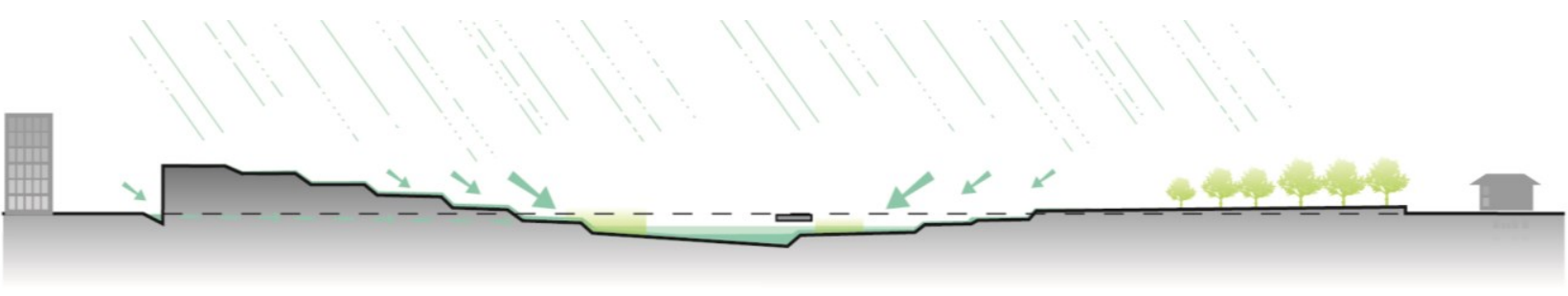

Illustration 59 Water runoff collection

The agricultural process is typically a polluting one, with water runoff collecting chemicals from the land and contaminating water bodies. As the Experimental Farm's research includes investigating the health of water bodies, diverting polluted city runoff into the site will showcase a healthy water system on the Farm as well as providing an amenity for the local community. Rather than allow the water to collect in storm

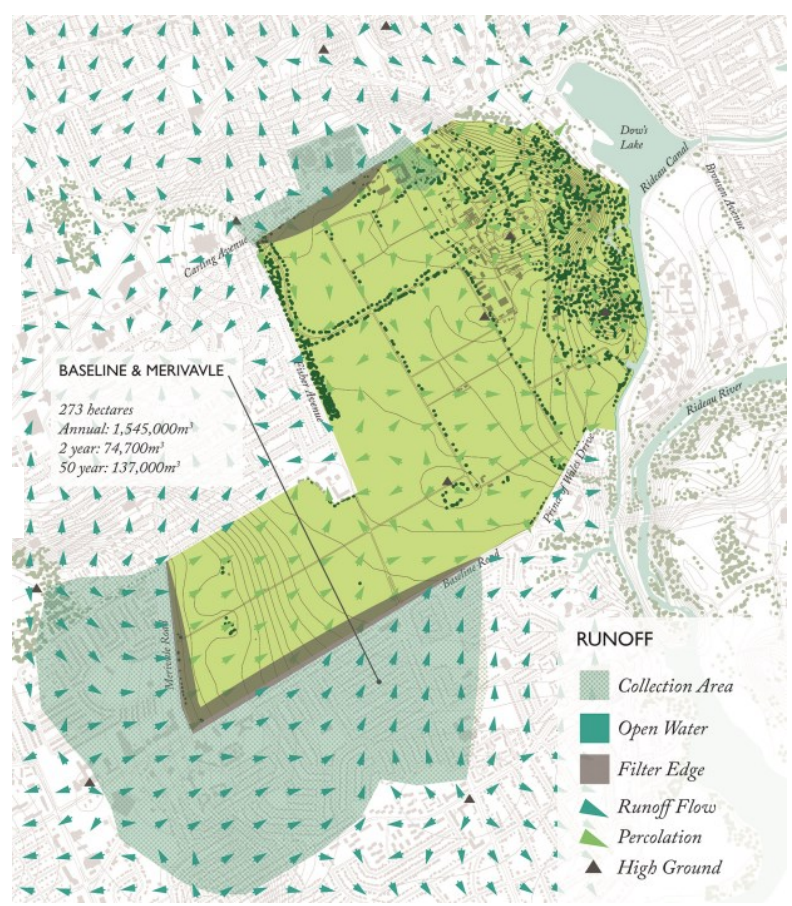

Illustration 60 Water runoff collection 
drains to be released into the Ottawa River, runoff water from a rainfall is collected along Merivale and Baseline roads, brought into the site by a downhill slope. For the water to be stored and used on the site, it must first be filtered of contaminants.

The water first passes over a bioswale planted with perennial grasses and clover to filter suspended solids, metals, grease and large particulates from the rainfall runoff through careful selection of plants and soils. ${ }^{29}$

The water is slowed with a series of check dams as it moves through the site which also form terraced reed beds for further filtration. The water is stored on the site for irrigating fields, watering the research greenhouses, and enhances the aesthetics of the site. Excess filtered water is released slowly into the wildlife garden or the Canal via the forest underpass.

By terracing the pools with check dams and reed beds, the difference in height allows for the aeration of the water to further improve its quality. The reed beds provide a diversity of habitats for wildlife, adding to the site's appeal. Elevated pathways keep the visitors above the water level, with sections that branch off to bring the visitor closer to the water. During times of high rainfall, large areas of the site and some smaller trails may be flooded and inaccessible, to be revealed again as the water flows into the reservoir.

\footnotetext{
${ }^{29}$ USA. State of Oregon. Department of Environmental Quality. BIOFILTERS (Bioswales, Vegetative Buffers, \& Constructed Wetlands) For Storm Water Discharge Pollution Removal. By Dennis Jurries. DEQ, 2003.
} 


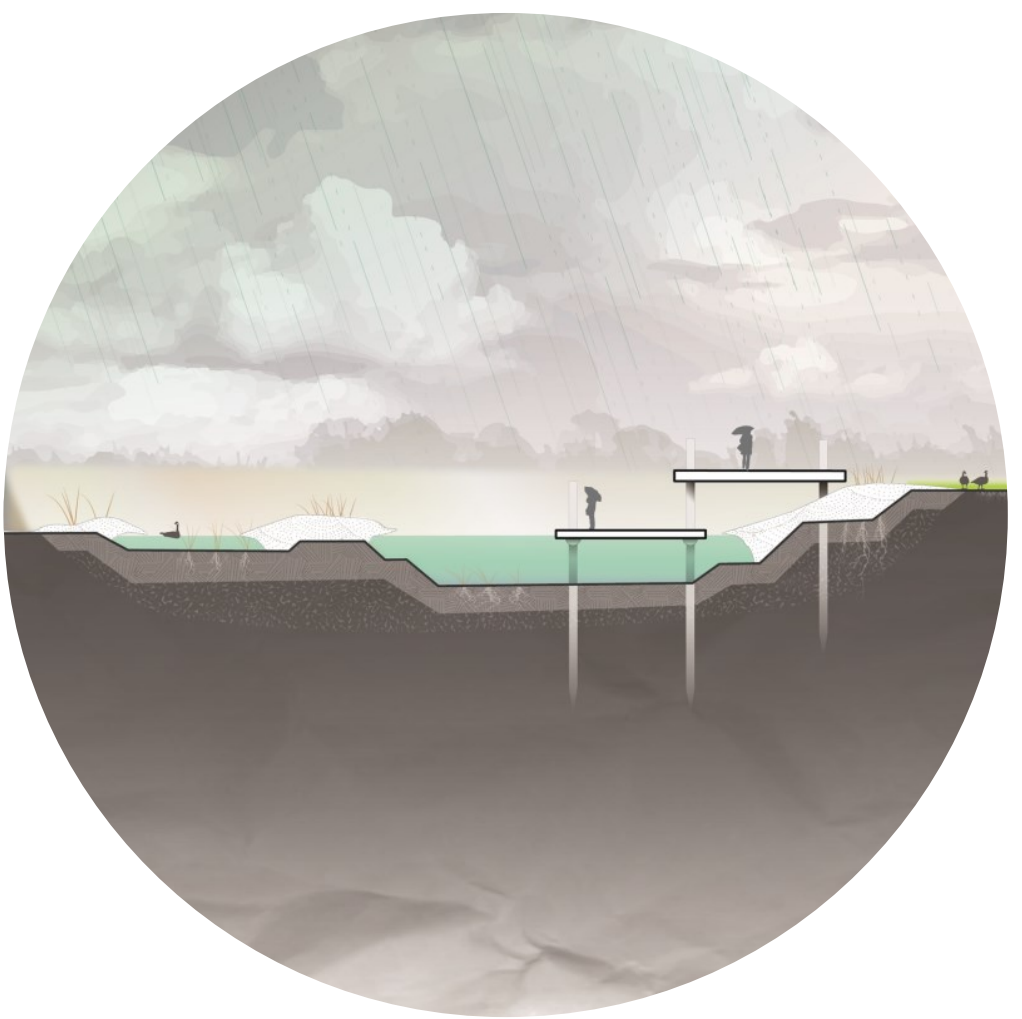

Illustration 61 Early spring/high water

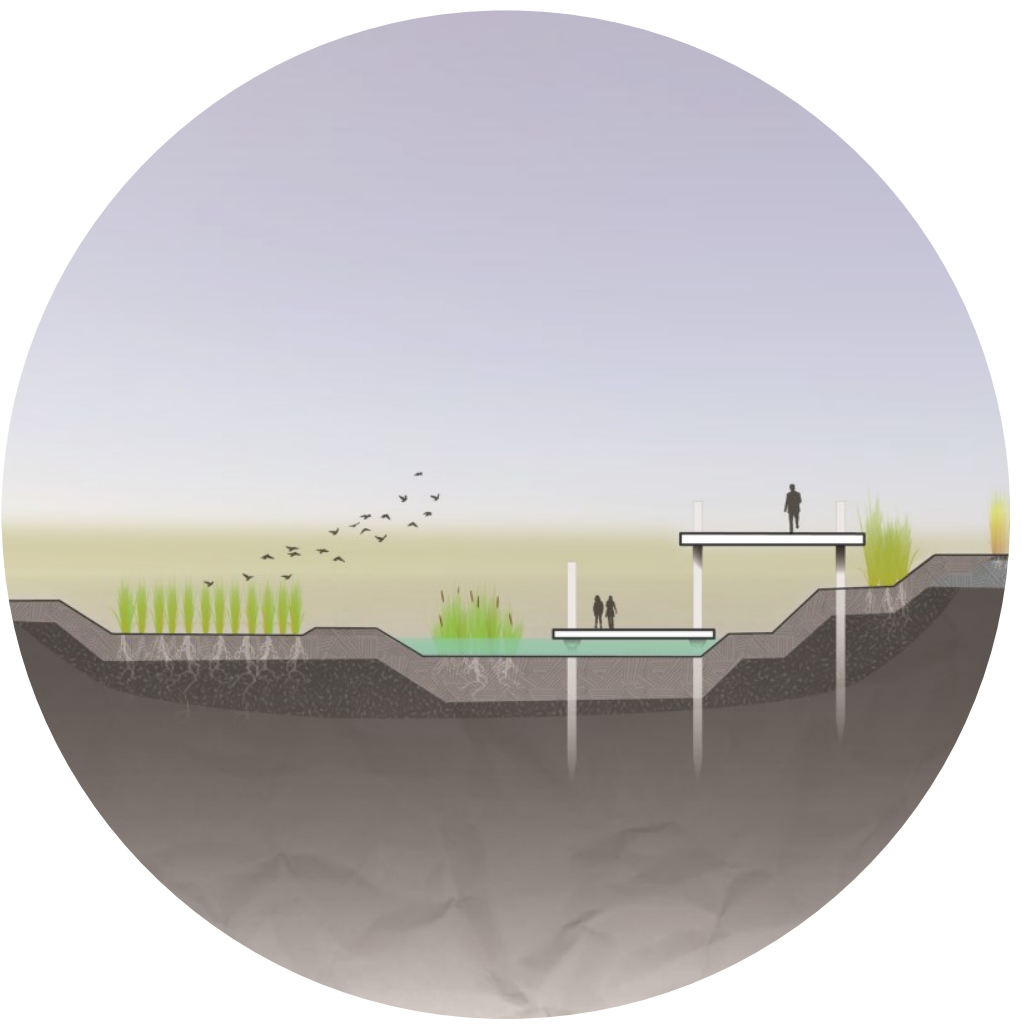

Illustration 62 Late summer/low water 


\section{Social}

The districts to the north of the Farm above

Carling Avenue are designated as mature

neighbourhoods, and will likely maintain their

character and density unlike the less developed

edge along Baseline Road. The Baseline edge

is currently low-density suburban housing,

however its proximity to the city's centre and

the regenerated Farm will spur higher-density

development.

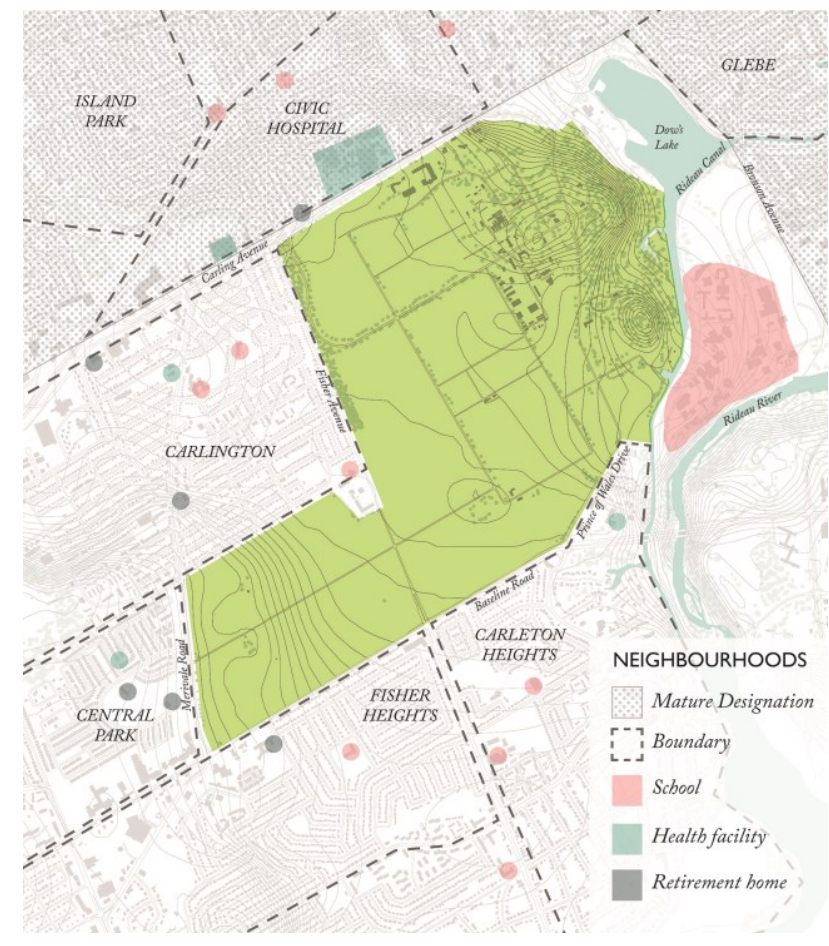

Illustration 63 Local amenities and neighbourhoods

There are several schools in the area, ranging from elementary to post-secondary, as well as multiple healthcare facilities such as the Civic Hospital and several retirement homes.

While areas of the site are raised and lowered, the main paths of the site are at the existing grade, which is relatively flat and accessible. Secondary paths provide the opportunity to follow the slopes up to lookout points such as the research edge and the bridge.

Community gardens and allotments are another way of engaging the site with the community, as local residents can put into practice a method demonstrated on the Farm, explore growing their own food by themselves or as part of a school project. The 
allotments engage people of all ages and gardening abilities. Rather than a one-time visit, the allotments require residents to invest time in the site with multiple visits per season. The hands-on activity is beneficial to all members of the community, particularly retirement residents, young children and those who may not otherwise have access to an outdoor space of their own.

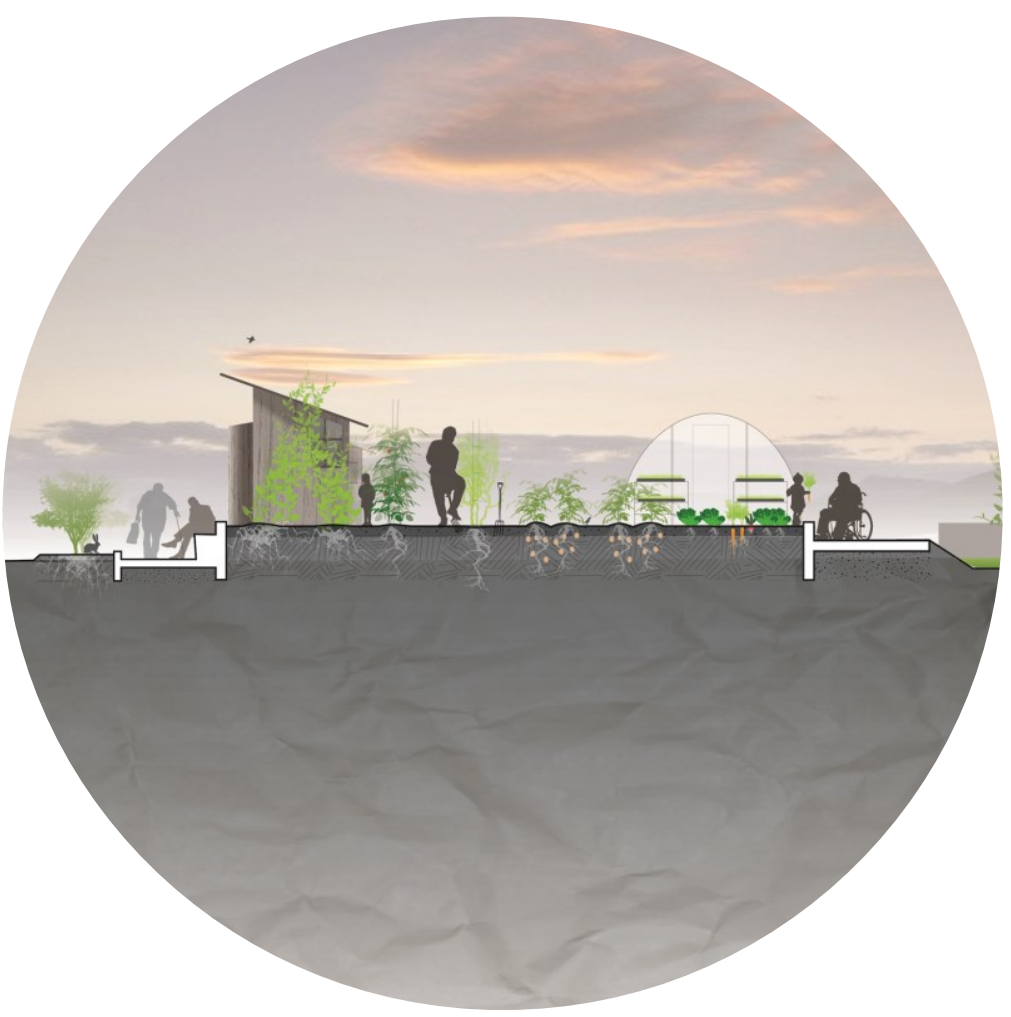

Illustration 64 Allotment gardens 


\section{CHAPTER 5: CONCLUSION}

This thesis aims to demonstrate that the landscape of the Experimental Farm can be regenerated through architecture and landscape architecture to reflect the environmental concerns of the general public such as local food production, climate change resiliency and the responsible treatment of city's runoff water.

The new topography creates a strong identity for the site by defining its edges in response to the changing surrounding city, and protecting the interior of the Farm for public recreation and scientific research. The topographic alterations are sensitive to the Farm's heritage values as a site of continuous research, its role of shaping agricultural research in Canada, and as unique example of a working farm in a city. By increasing the site's appeal to visitors by providing more diverse, public-oriented programming, these heritage and scientific values can be appreciated by future generations, along with an appreciation of the site's natural processes. 
CHAPTER 6: DESIGN IMAGES 


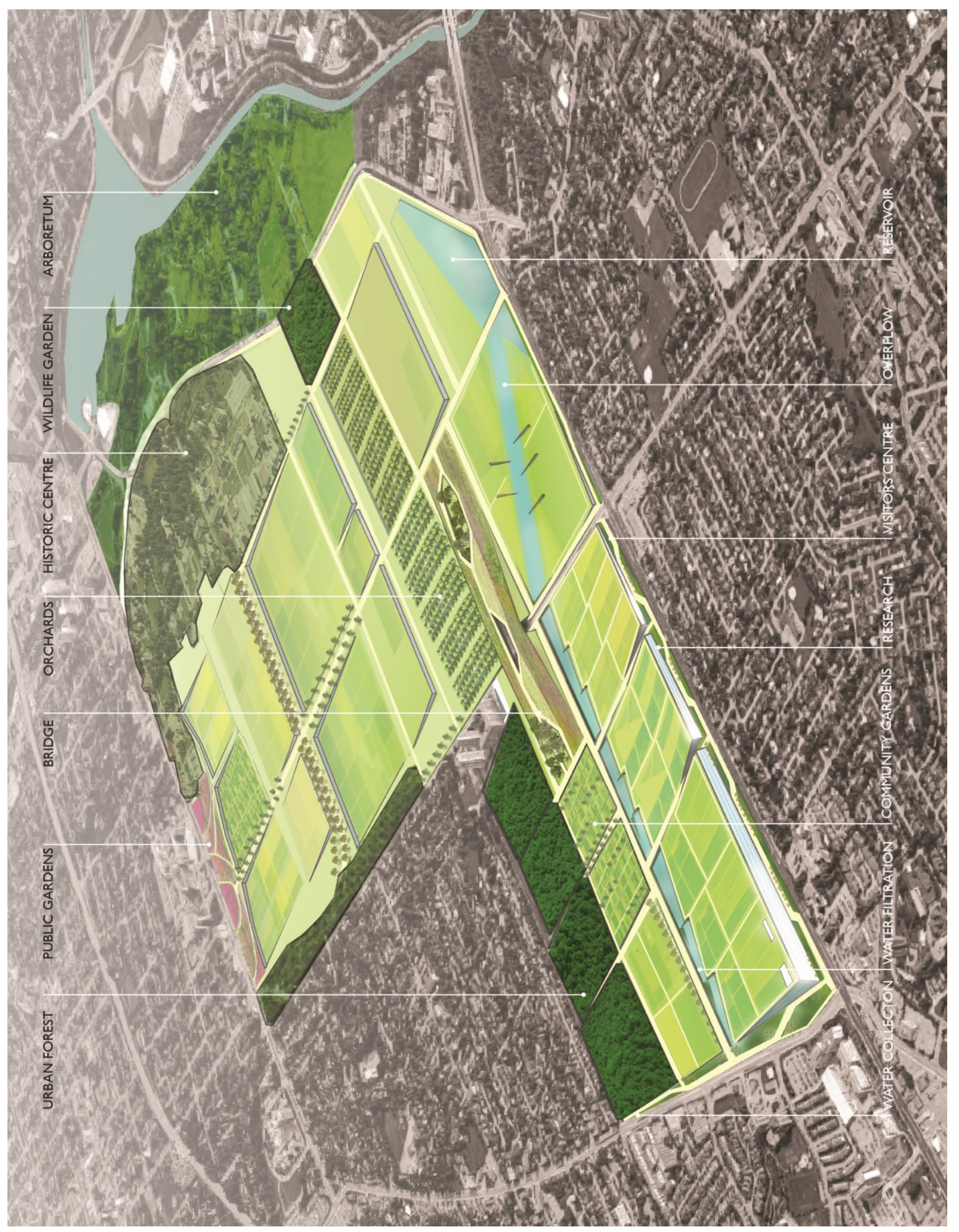

Illustration 65-Proposed Site 


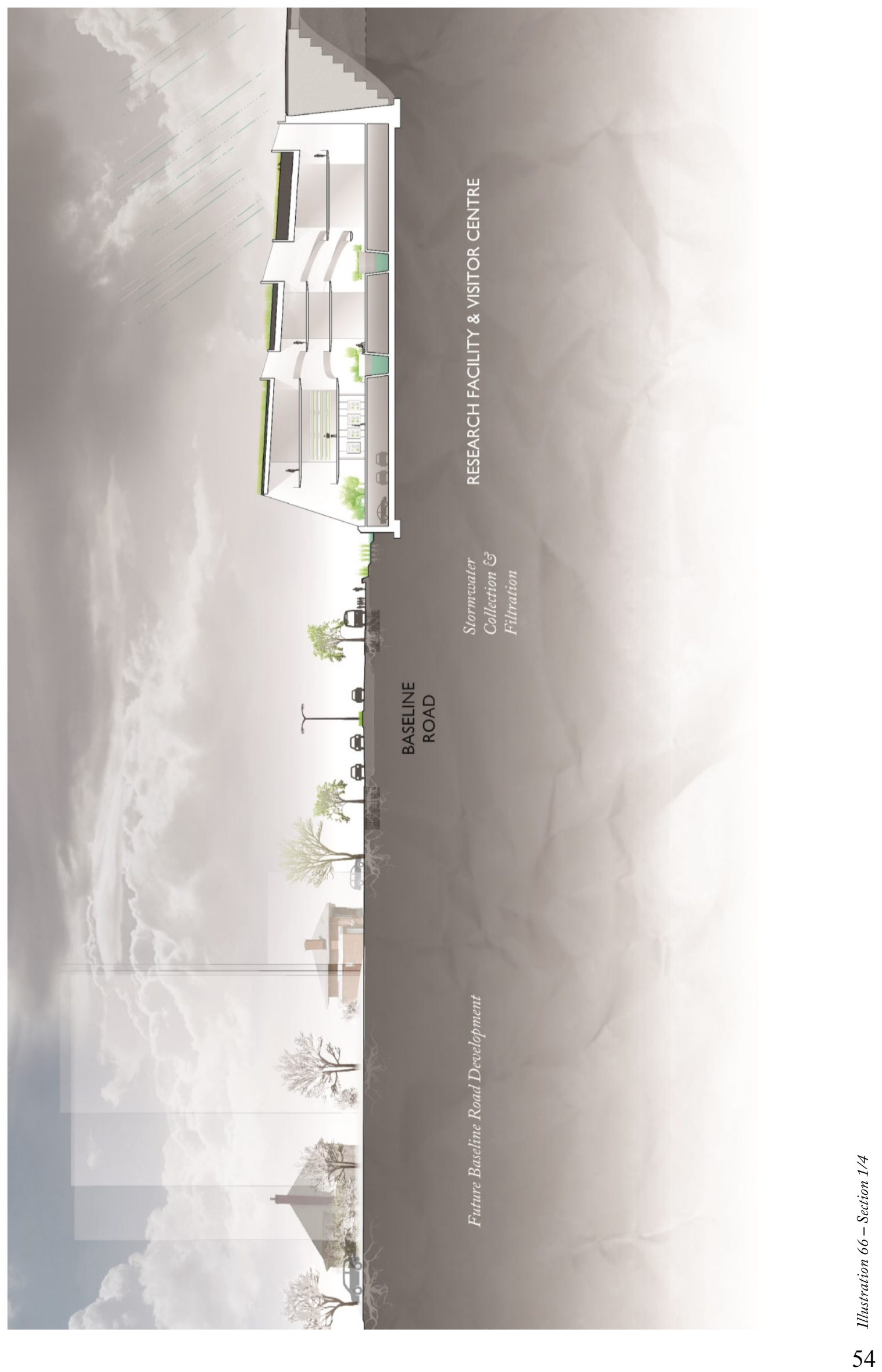




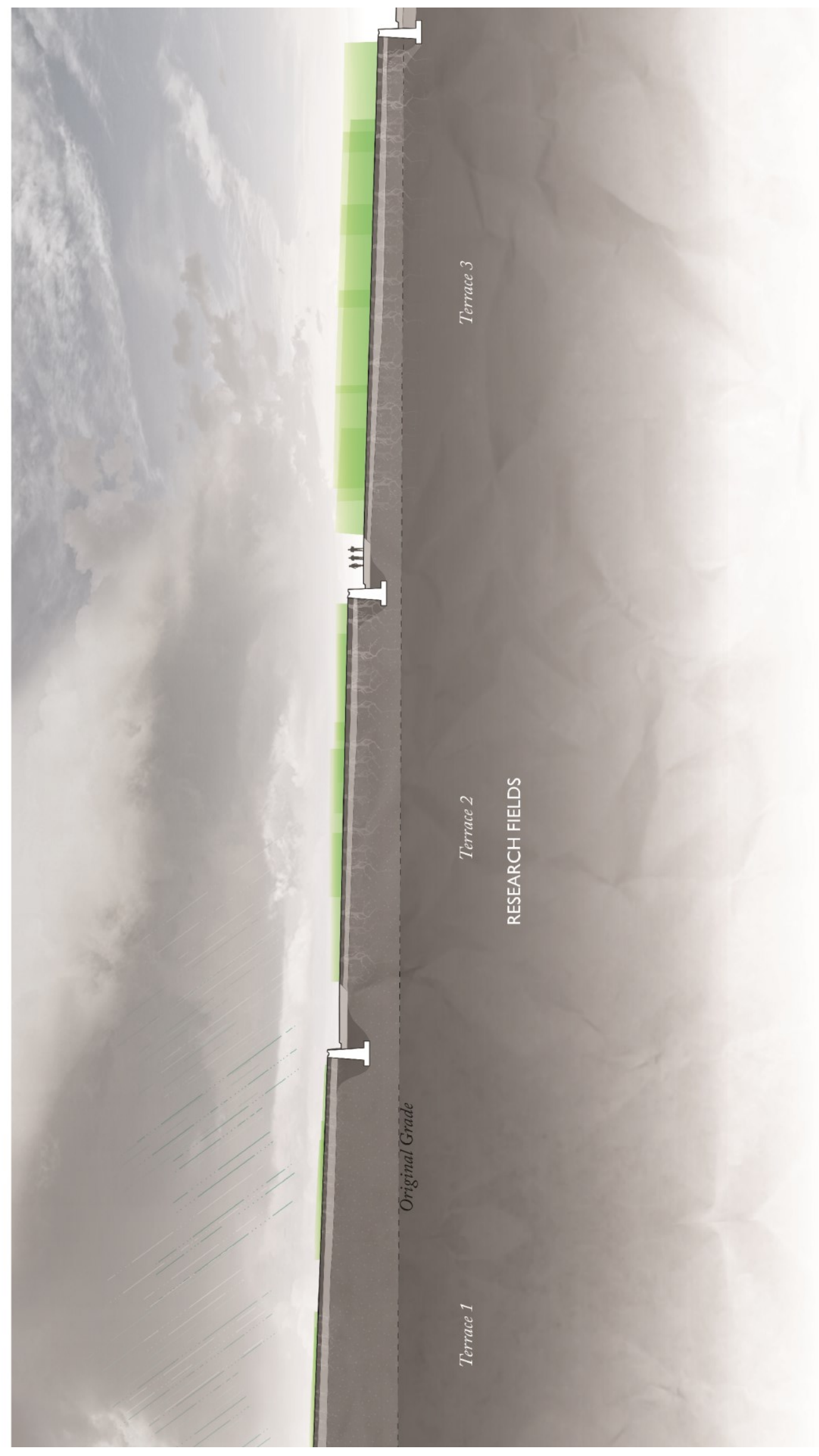




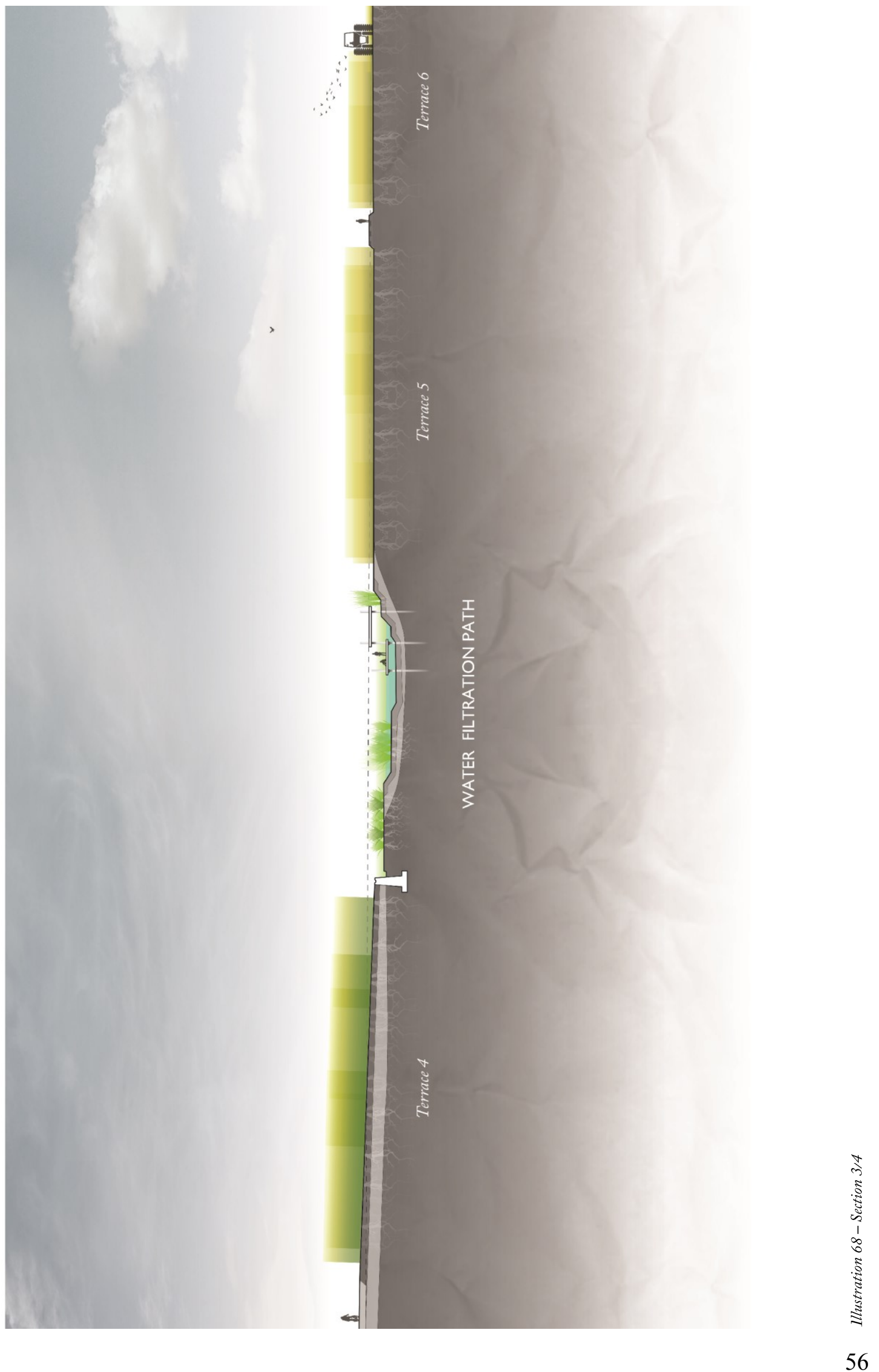




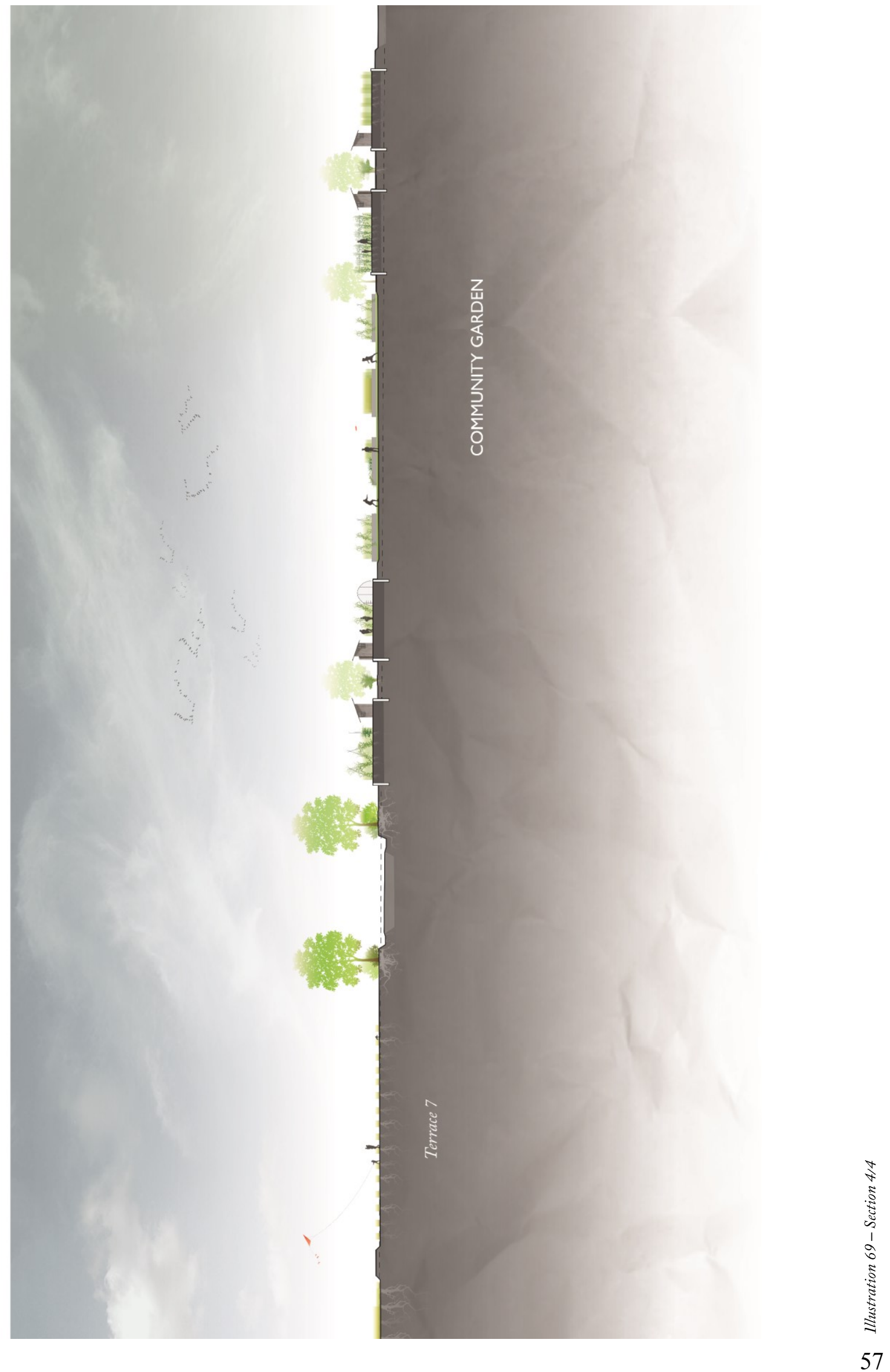




\section{APPENDICES}

\section{Appendix $A$}

\section{A.1 Intensity Duration Frequency Chart for Ottawa}

From Canadian Climate Normals ${ }^{30}$

1981 to 2010 Canadian Climate Normals station data.

Return period rainfall rates $(\mathrm{mm} / \mathrm{hr})-95 \%$ confidence limits.

\begin{tabular}{|c|c|c|c|c|c|c|}
\hline DURATION & $2 \mathrm{YR}$ & $5 \mathrm{YR}$ & $10 \mathrm{YR}$ & $25 \mathrm{YR}$ & $50 \mathrm{YR}$ & $100 \mathrm{YR}$ \\
\hline $5 \mathrm{MIN}$ & $\begin{array}{ll}104.1+/- \\
7.9\end{array}$ & $\begin{array}{l}130.2 \\
+/-13.2\end{array}$ & $\begin{array}{l}147.6 \\
+/-17.9\end{array}$ & $\begin{array}{c}169.5 \\
+/-24.1\end{array}$ & $\begin{array}{l}185.7 \\
+/-28.8\end{array}$ & $\begin{array}{l}201.8 \\
+/-33.6\end{array}$ \\
\hline $10 \mathrm{MIN}$ & $\begin{array}{l}74.5 \\
+/-5.9\end{array}$ & $\begin{array}{l}94.3 \\
+/-10.0\end{array}$ & $\begin{array}{l}107.4 \\
+/-13.5\end{array}$ & $\begin{array}{l}124.0 \\
+/-18.2\end{array}$ & $\begin{array}{l}136.3 \\
+/-21.8\end{array}$ & $\begin{array}{l}148.5 \\
+/-25.4\end{array}$ \\
\hline $15 \mathrm{MIN}$ & $\begin{array}{l}61.5 \\
+/-5.1\end{array}$ & $\begin{array}{l}78.7 \\
+/-8.5\end{array}$ & $\begin{array}{l}90.2 \\
+/-11.5\end{array}$ & $\begin{array}{l}104.5 \\
+/-15.5\end{array}$ & $\begin{array}{l}115.2 \\
+/-18.6\end{array}$ & $\begin{array}{l}125.8 \\
+/-21.6\end{array}$ \\
\hline $30 \mathrm{MIN}$ & $\begin{array}{l}39.2 \\
+/-3.3\end{array}$ & $\begin{array}{l}50.2 \\
+/-5.5\end{array}$ & $\begin{array}{ll}57.5 \quad+/- \\
7.4\end{array}$ & $\begin{array}{l}66.8 \\
+/-10.0\end{array}$ & $\begin{array}{l}73.7 \\
+/-11.9\end{array}$ & $\begin{array}{l}80.5 \\
+/-13.9\end{array}$ \\
\hline $1 \mathrm{HR}$ & $\begin{array}{l}24.2 \\
+/-2.1\end{array}$ & $\begin{array}{l}31.3 \\
+/-3.6\end{array}$ & $\begin{array}{l}36.1 \\
+/-4.8\end{array}$ & $\begin{array}{l}42.1 \\
+/-6.5\end{array}$ & $\begin{array}{l}46.6 \\
+/-7.8\end{array}$ & $\begin{array}{l}51.0 \\
+/-9.0\end{array}$ \\
\hline $2 \mathrm{HR}$ & $\begin{array}{l}14.1 \\
+/-1.3\end{array}$ & $\begin{array}{l}18.4 \\
+/-2.1\end{array}$ & $\begin{array}{l}21.3 \\
+/-2.9\end{array}$ & $\begin{array}{l}24.9 \\
+/-3.9\end{array}$ & $\begin{array}{l}27.6 \\
+/-4.7\end{array}$ & $\begin{array}{l}30.3 \\
+/-5.4\end{array}$ \\
\hline $6 \mathrm{HR}$ & $\begin{array}{l}6.1 \\
+/-\quad .6\end{array}$ & $\begin{array}{l}8.0 \\
+/-1.0\end{array}$ & $\begin{array}{l}9.3 \\
+/-1.3\end{array}$ & $\begin{array}{l}10.9 \\
+/-1.8\end{array}$ & $\begin{array}{l}12.2 \\
+/-2.1\end{array}$ & $\begin{array}{l}13.4 \\
+/-2.5\end{array}$ \\
\hline $12 \mathrm{HR}$ & $\begin{array}{l}3.5 \\
+/-\quad .3\end{array}$ & $\begin{array}{l}4.6 \\
+/-\quad .5\end{array}$ & $\begin{array}{l}5.3 \\
+/-\quad .7\end{array}$ & $\begin{array}{l}6.1 \\
+/-.9\end{array}$ & $\begin{array}{l}6.8 \\
+/-1.1\end{array}$ & $\begin{array}{l}7.4 \\
+/-1.3\end{array}$ \\
\hline $24 \mathrm{HR}$ & $\begin{array}{l}1.9 \\
+/-.1\end{array}$ & $\begin{array}{l}2.4 \\
+/-\quad .2\end{array}$ & $\begin{array}{l}2.8 \\
+/-\quad .3\end{array}$ & $\begin{array}{l}3.2 \\
+/-.4\end{array}$ & $\begin{array}{l}3.5 \\
+/-\quad .5\end{array}$ & $\begin{array}{l}3.8 \\
+/-\quad .6\end{array}$ \\
\hline
\end{tabular}

30 "Ottawa - Canadian Climate Normals." Environment Canada. Accessed February 2, 2016. http://climate.weather.gc.ca/climate_normals/index_e.html. 


\section{A.2 Runoff Volume Calculations}

The Rational Equation was used to estimate storm water runoff volumes: ${ }^{31}$

$$
Q=\frac{c i A}{360}
$$

Where:

$$
\begin{aligned}
& Q=\text { peak discharge }, \mathrm{m}^{3} / \mathrm{s} \\
& c=\text { runoff coefficient } \\
& i=\text { rainfall intensity from Intensity Duration Frequency chart, } \mathrm{mm} / \mathrm{hr} \\
& A=\text { drainage area, hectares } \\
& 360=\text { metric conversion }
\end{aligned}
$$

As the drainage area in the calculation was a mix of hard and soft surfaces, a hybrid runoff coefficient was derived for $c$ from the following:

$$
\begin{array}{ll}
40 \% \text { porous surfaces } & c_{1}=0.3 \\
60 \% \text { non-porous surfaces } & c_{2}=0.9 \\
100 \% \text { of area } & c=c_{2}-c_{1} \\
& c=0.6
\end{array}
$$

Rainfall intensity duration was calculated for a $24 \mathrm{hr}, 2$ year event to design for more frequent storm events, and for a $24 \mathrm{hr}, 50$ year event for larger capacities.

To calculate the total volume of water from the peak discharge, the peak rate was multiplied by the time specified in the rainfall intensity:

Where:

$$
V=Q t
$$

$$
\begin{aligned}
& V=\text { rainfall volume }, \mathrm{m}^{3} \\
& Q=\text { peak discharge }, \mathrm{m}^{3} / \mathrm{s} \\
& t=\text { time as used for } i, \text { in seconds }
\end{aligned}
$$

\footnotetext{
31 "Drainage Design." Watershed Management Field Manual. Food and Agriculture Organisation of the United Nations.. Accessed March 31, 2016. http://www.fao.org/docrep/006/t0099e/t0099e04.htm.
} 
2 year event:

Peak Discharge: $Q=\frac{c i A}{360}$

Where: $\quad c=0.6$

$\boldsymbol{i}_{\mathbf{2} \boldsymbol{y r}}=1.9 \mathrm{~mm} / \mathrm{hr}$

$A=273 b a$

$$
\begin{aligned}
Q_{2 y r} & =\frac{c i_{2 y r} A}{360} \\
& =\frac{(0.6)(1.9 m m / h r)(273 h a)}{360} \\
& =0.86 m^{3} / \mathrm{s}
\end{aligned}
$$

Total volume: $V_{2 y r}=Q_{2 y r} t$

Where : $\quad \boldsymbol{Q}_{\mathbf{2}} \boldsymbol{y r}=0.86 \mathrm{~m}^{3} / \mathrm{s}$

$t=86400 s$ (24 hours)

$V_{2 y r}=Q_{2 y r} t$

$=\left(0.86 \mathrm{~m}^{3} /\right.$

s) $86400 \mathrm{~s}$

$=74,700 \mathrm{~m}^{3}$

$\therefore$ the total water entering the site during a 2 year storm is $74,700 \mathrm{~m}^{3}$.

50 year event:

Peak Discharge: $\boldsymbol{Q}=\frac{\boldsymbol{c i \boldsymbol { A }}}{\mathbf{3 6 0}}$

Where $: c=0.6$

$$
\begin{aligned}
& \boldsymbol{i}_{\mathbf{5 0} \boldsymbol{y r}}=3.5 \mathrm{~mm} / \mathrm{hr} \\
& A=273 \mathrm{ha}
\end{aligned}
$$

$$
\begin{aligned}
Q_{50 y r} & =\frac{c i_{50 y r} A}{360} \\
& =\frac{(0.6)(3.5 m m / h r)(273 h a)}{360} \\
& =1.6 m^{3} / \mathrm{s}
\end{aligned}
$$

Total volume: $\boldsymbol{V}_{\mathbf{5 0} \boldsymbol{y r}}=\boldsymbol{Q}_{\mathbf{5 0} \boldsymbol{y r}} \boldsymbol{t}$

Where: $\quad \boldsymbol{Q}_{\mathbf{5 0} \boldsymbol{y r}}=1.6 \mathrm{~m}^{3} / \mathrm{s}$

$$
t=86400 \text { s ( } 24 \text { hours) }
$$

$V_{50 y r}=Q_{50 y r} t$

$=\left(1.6 \mathrm{~m}^{3} /\right.$

s) $86400 \mathrm{~s}$

$=137,000 \mathrm{~m}^{3}$

$\therefore$ the total water entering the site during a 50 year storm is $137,000 \mathrm{~m}^{3}$. 


\section{A.3 Annual Rainfall Calculations}

To estimate the volume of annual rainfall collected by the site, the following equation was used: $:^{32} \quad V=R a e$

Where: $\quad V=$ rainfall collected, litres.

$R=$ average annual rainfall

$A=$ area of rainfall to be calculated, $\mathrm{m}^{2}$

$e=$ surface coefficient

\section{Experimental Farm:}

$$
V=R A e
$$

Where: $\quad R=943.5 \mathrm{~mm}$ (average for Ottawa)

$$
\begin{aligned}
\mathrm{A} & =2.73 \times 10^{\wedge 6} \mathrm{~m}^{2}(273 \mathrm{ha}) \\
e & =0.6 \\
V & =943.5 \mathrm{~mm}\left(2.73 \times 10^{6} \mathrm{~m}^{2}\right) 0.6 \\
& =1545453000 \mathrm{l} \\
& =\mathbf{1}, \mathbf{5 4 5}, \mathbf{0 0 0 m ^ { 3 }}
\end{aligned}
$$

$\therefore$ the total water entering site per year is $1,545,000 \mathrm{~m}^{3}$.

This method is a rough approximation and does not account for evaporation, interception, diversion or other factors and barriers that would affect rainfall collection.

\footnotetext{
32 "Rainfall-runoff Analysis." Water Harvesting. Food and Agriculture Organisation of the United Nations. Accessed March 31, 2016. http://www.fao.org/docrep/u3160e/u3160e05.htm.
} 


\section{BIBLIOGRAPHY}

2015-16 Report on Plans and Priorities." Agriculture and Agri-Food

Canada;Government of Canada. Accessed January 30, 2016.

http://www.agr.gc.ca/eng/about-us/planning-and-reporting/reports-on-plans-and-

priorities/2015-16-report-on-plans-and-priorities/?id=1422918881954.

"AGRICULTURE." Agriculture and Climate Change. Accessed January 5, 2016. http://www.climate.org/topics/agriculture.html.

Birchard, Karen, and Jennifer Lewington. "Dispute Over the Future of Basic Research in Canada." The New York Times, January 16, 2014, Americas sec. Accessed January 4, 2015. http://www.nytimes.com/2014/02/17/world/americas/dispute-over-thefuture-of-basic-research-in-canada.html?ref=canada\&_r=0.

Canada and the Kyoto Protocol." David Suzuki Foundation. Accessed January 5, 2016. http://www.davidsuzuki.org/issues/climate-change/science/canada-climatechange/canada-and-kyoto/.

Canada. Industry Canada. Canada's Innovation Strategy: New Ideas, New Opportunities. Ottawa: Govt. of Canada, 2002.

"Central Experimental Farm National Historic Site Management Plan." Central Experimental Farm Integrated Services; Agriculture and Agri-Food Canada; Government of Canada. May 08, 15. Accessed March 16, 2016. http://www.agr.gc.ca/eng/about-us/offices-and-locations/central-experimentalfarm/about-the-central-experimental-farm/central-experimental-farm-national- 
historic-site-management-plan-1-of-20/central-experimental-farm-nationalhistoric-site-management-plan-4-of-20/?id=1170421393729.

Climate Change [B. Metz, O.R. Davidson, P.R. Bosch, R. Dave, L.A. Meyer (eds)], Cambridge University Press, Cambridge, United Kingdom and New York, NY, USA.

"Drainage Design." Watershed Management Field Manual. Food and Agriculture Organisation of the United Nations.. Accessed March 31, 2016. http://www.fao.org/docrep/006/t0099e/t0099e04.htm.

Facts, Figures and Facilities, "Ottawa Research and Development Centre." ECORC;Agriculture and Agri-Food Canada;Government of Canada. November 24, 2015. Accessed January 2, 2016. http://www.agr.gc.ca/eng/science-andinnovation/research-centres/ontario/ottawa-research-and-developmentcentre/?id=1180546650582.

"Formative Evaluation of the Historic Places Initiative." Parks Canada. Accessed January 30, 2016. http://www.pc.gc.ca/docs/pc/rpts/rve-par/21/3_e.asp.

Jolley, Rachael. "Cuts and Red Tape Are Gagging US and Canadian Science." New Scientist, April 9, 2014.

Mancini, Melissa. "Science Cuts And Muzzling In Canada: How Conservatives Reshaped A Discipline." The Huffington Post Canada, April 30, 2015. Accessed January 4, 2015. http://www.huffingtonpost.ca/2013/04/30/science-cuts-muzzlingcanada-conservatives_n_3112348.html. 
Mandel, Charles. "Canada's Remarkable Turn-around on Climate Needs to Be Backed by Policy: Stephen Lewis." National Observer, December 8, 2015, News sec. Accessed January 5, 2016. http://www.nationalobserver.com/2015/12/08/news/canadas-remarkable-turnaround-climate-needs-be-backed-policy-stephen-lewis.

Nederhoff, Elly, Dr. "LEDs in Spotlight." Greenhouse Canada, September 27, 2011

"Ottawa - Canadian Climate Normals." Environment Canada. Accessed February 2, 2016. http://climate.weather.gc.ca/climate_normals/index_e.html.

Prystupa, Mychaylo. "Canada Should Re-ratify Kyoto, Says Elizabeth May." National Observer, November 28, 2015, News sec. Accessed January 5, 2015.

"Rainfall-runoff Analysis." Water Harvesting. Food and Agriculture Organisation of the United Nations. Accessed March 31, 2016. http://www.fao.org/docrep/u3160e/u3160e05.htm.

Reevely, Paul. "Http://www.ottawacitizen.com/light Rail Carling avenue/8329830/story.html." Ottawa Citizen, May 1, 2013, Ottawa sec. Accessed January 6, 2016.

"Science and Scientists." Liberal Party of Canada. Accessed January 4, 2016. http://www.liberal.ca/realchange/science-and-scientists/\#0. 
Sgro, Judy. Canada's Urban Strategy: A Vision for the 21st Century. Ottawa: Prime Minister's Caucus Task Force on Urban Issues, 2002.

Smith, P., et ai. 2007: Agriculture. In Climate Change 2007: Mitigation. Contribution of Working Group III to the Fourth Assessment Report of the Intergovernmental Panel on

Spears, Tom. "Explained: What Actually Happens at the Experimental Farm." Ottawa Citizen, November 13, 2015, Local sec. Accessed 2016.

USA. State of Oregon. Department of Environmental Quality. BIOFILTERS (Bioswales, Vegetative Buffers, \& Constructed Wetlands) For Storm Water Discharge Pollution Removal. By Dennis Jurries. DEQ 2003.

Walsh, Bryan. "Bienvenue Au Canada: Welcome to Your Friendly Neighborhood PetroState." Time, December 11, 2011.

Young, Emma. "Canada Ratifies Kyoto Protocol." New Scientist, December 17, 2002. 